\title{
أثر استخدام ربات الأسر لبعض الأجهزة المنزلية الحديثة على دافعيتهن للإنجاز وكفاءتهن الأدائية والإنتاجية
}

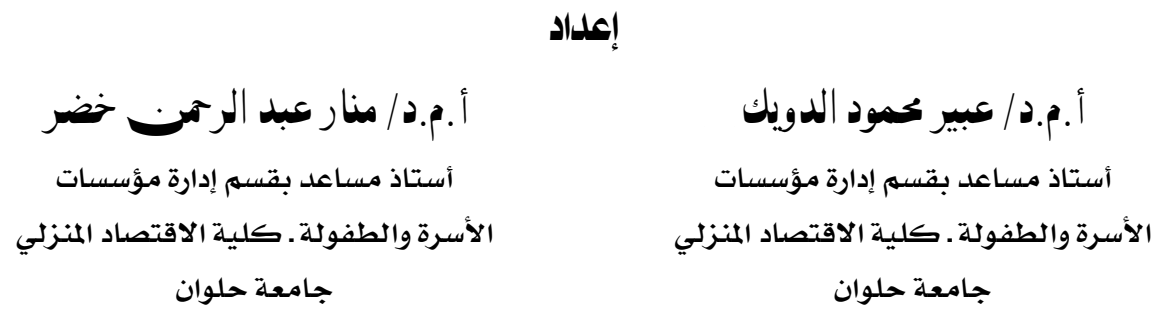

مجلة بحوث التربية النوعية - جامعة المنصورة

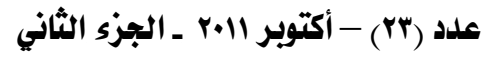




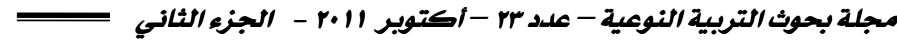 \\ أثر استخدام ربات الأسر لبعض الأجهزة المنزلية الهديثة على دافعيتهن للإنجاز وكفاء تهن الأدائية والإنتاجية
}

\author{
إعداد \\ أ أ.م.د/منار عبد الرحمخخض \\ * أ.م.د/عبر محمود الدويك
}

المقدهة والمشكلة البحثية :

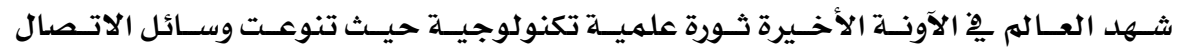

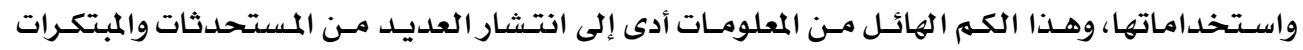

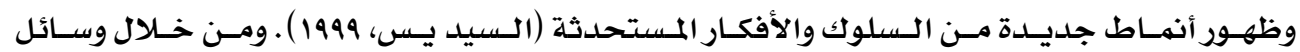

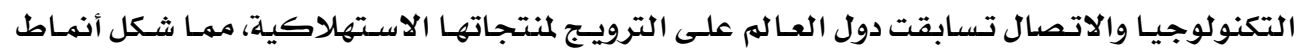

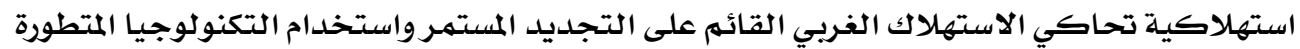

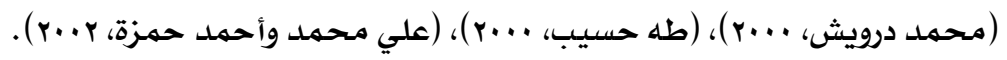

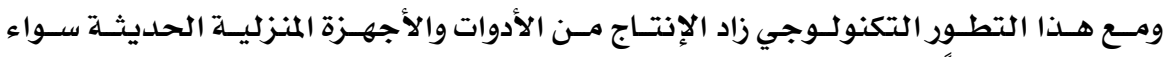

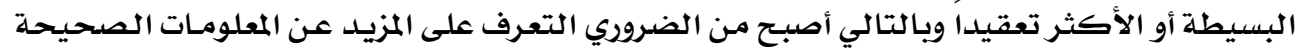

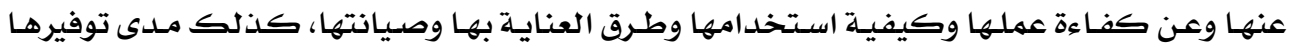

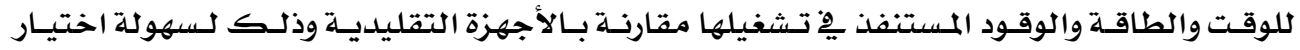

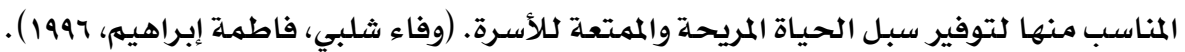
وهذا مـا أيدته دراسة Breager, 1977 أن من العوامل التي تؤثر عل عمل الأجهـزة المنزليـة المهية

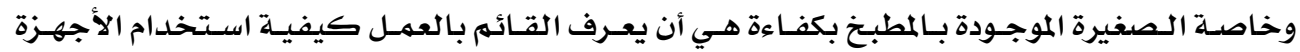

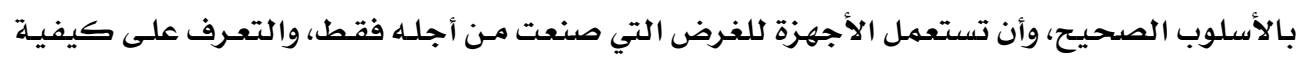

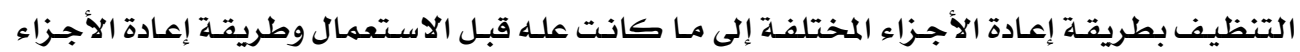

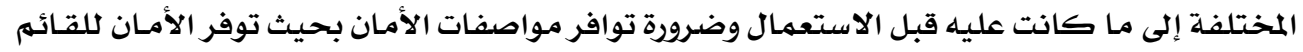

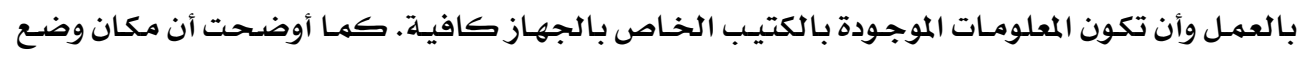

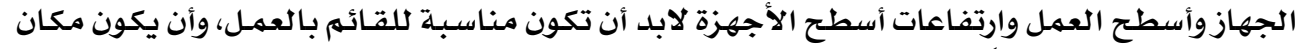

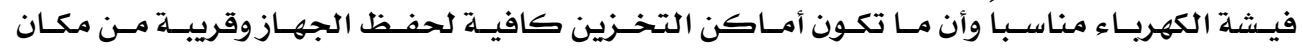
الاستخدام.

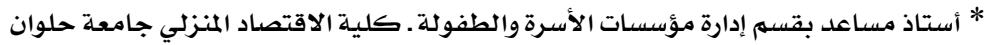

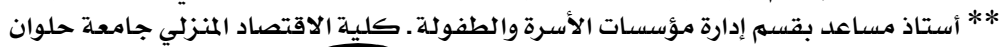




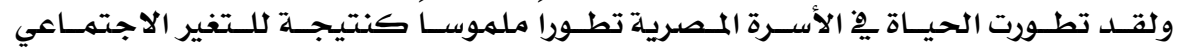

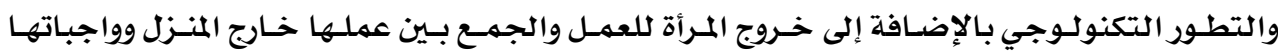

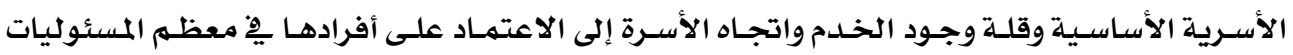

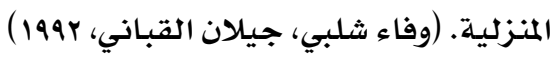

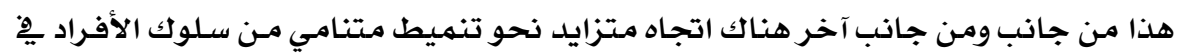

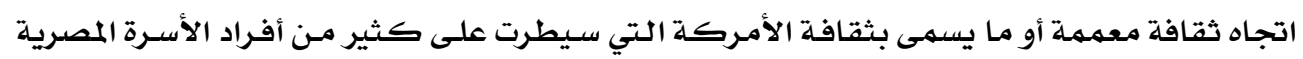

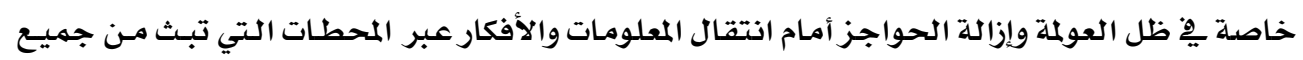

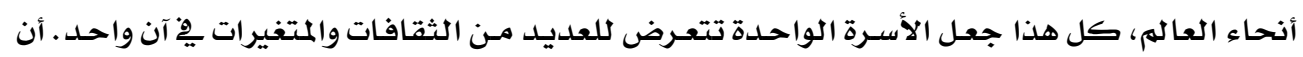

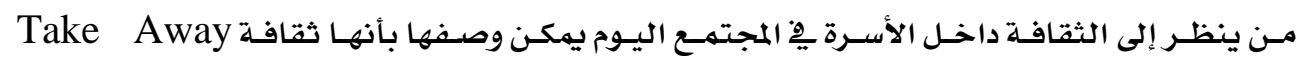

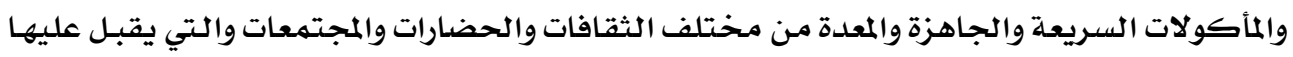

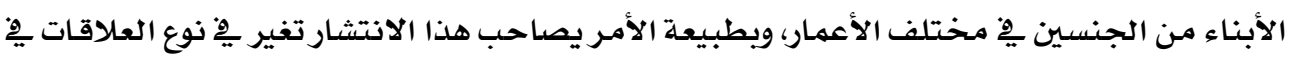

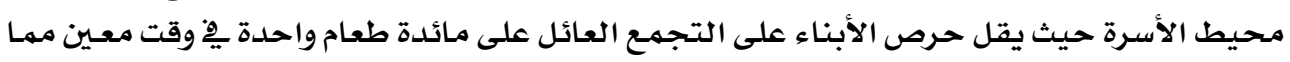

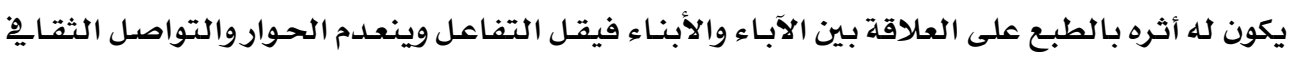

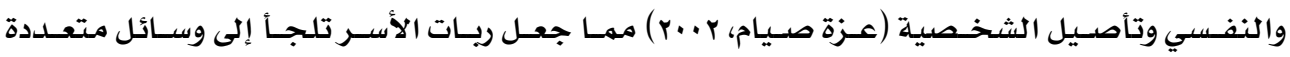

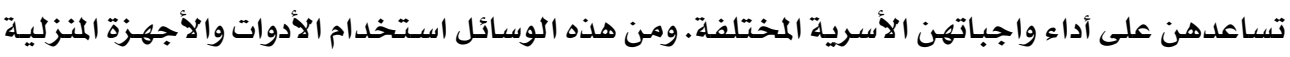

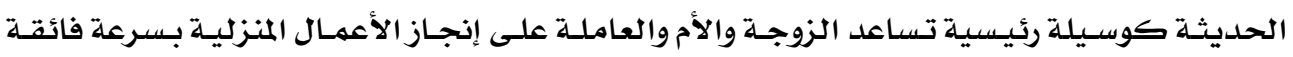

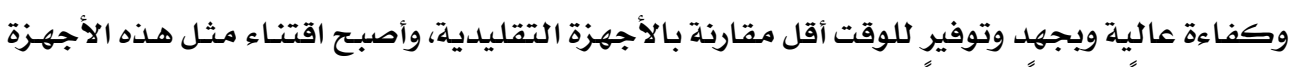

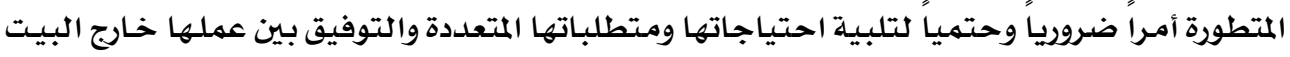

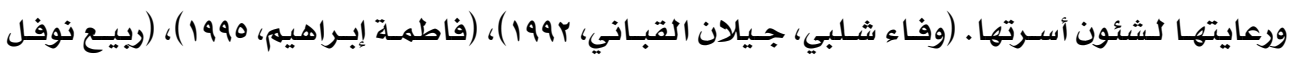

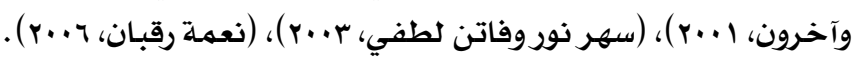

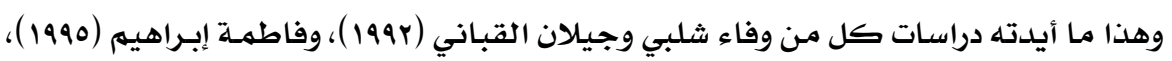

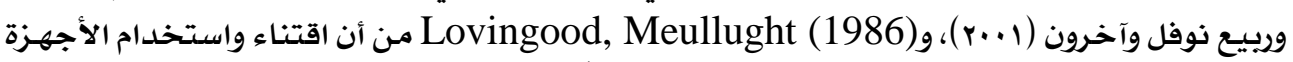

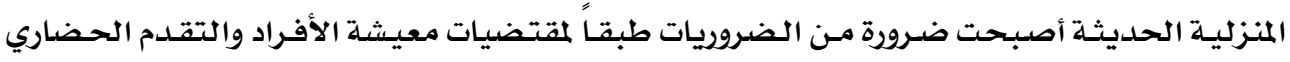

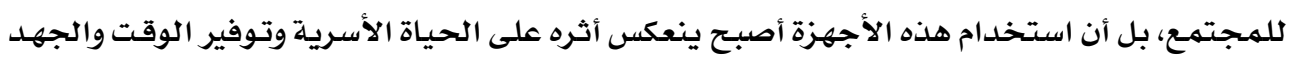

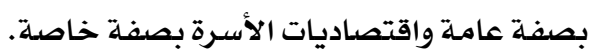

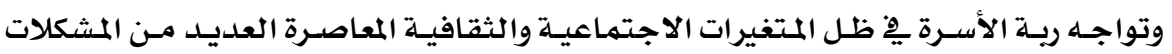

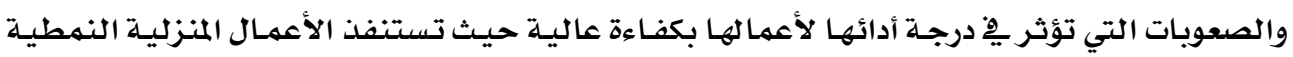

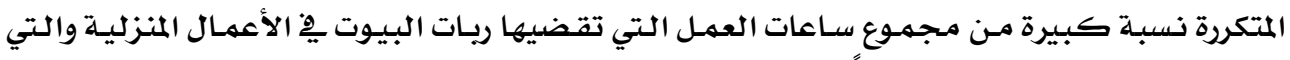

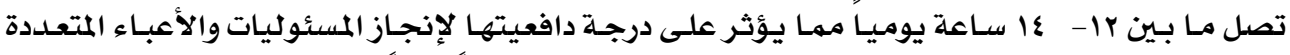

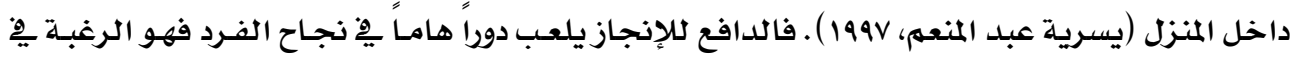

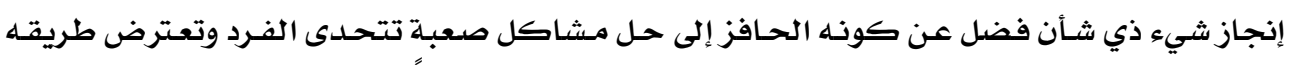

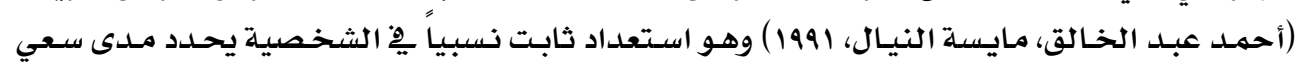




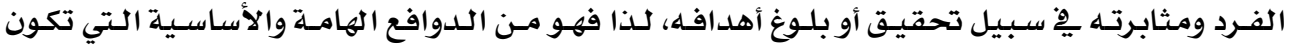

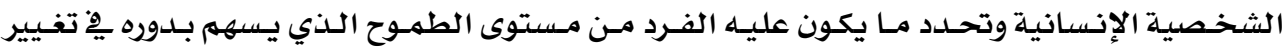

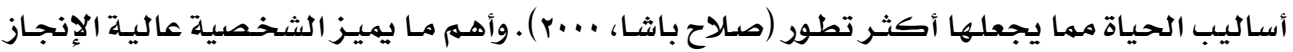

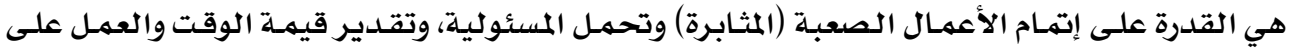

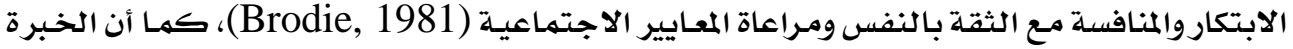

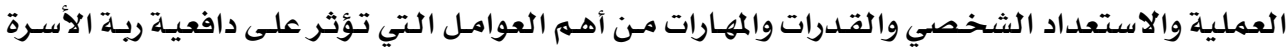

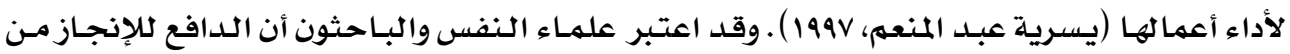

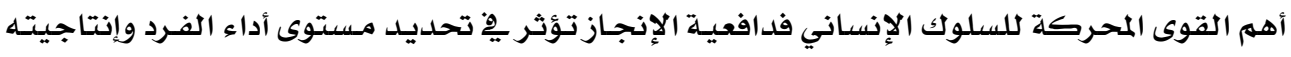

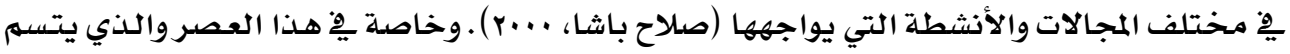

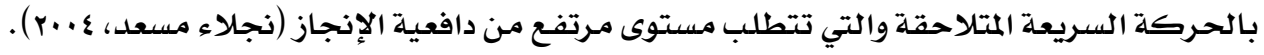

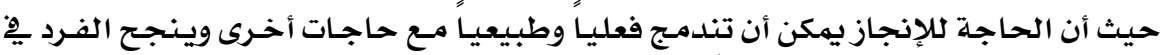

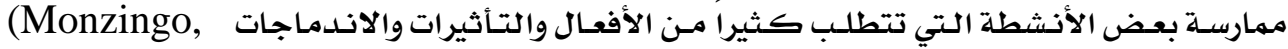

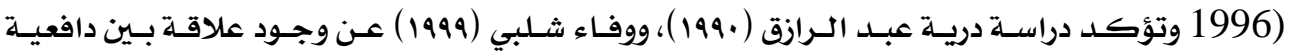

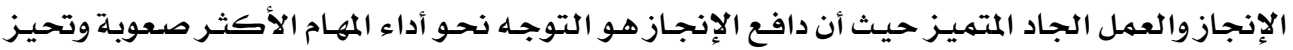

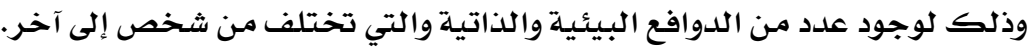

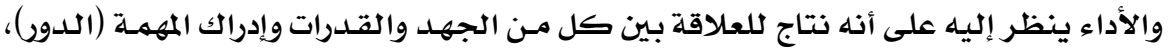

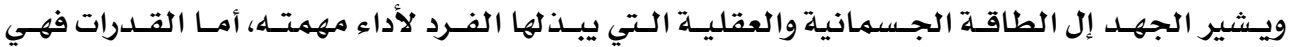

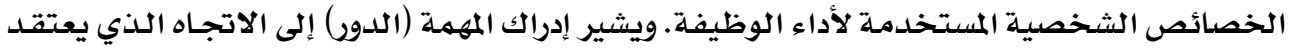

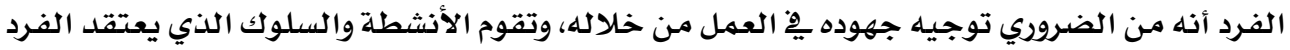

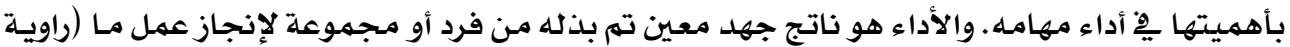
حسن، 1999).

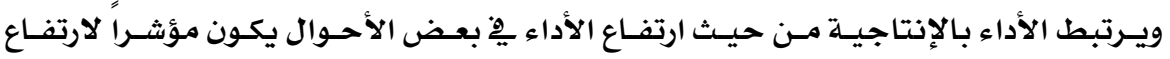

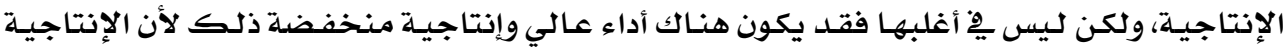

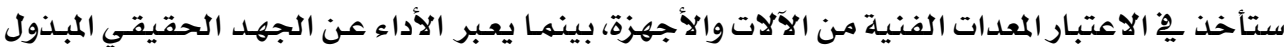

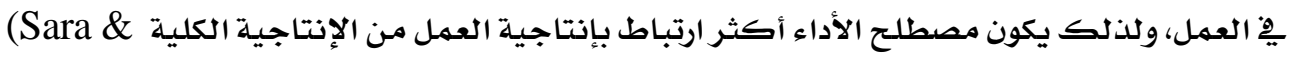

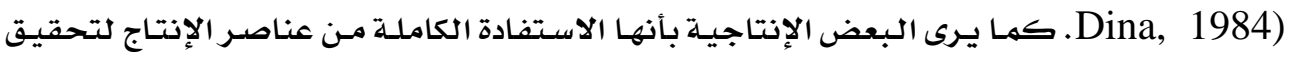

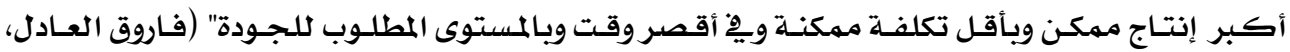

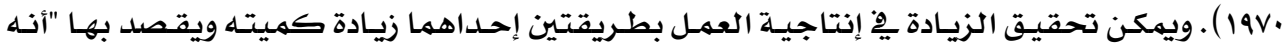

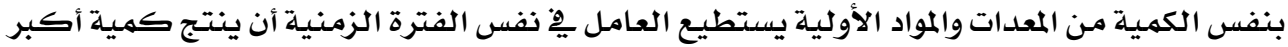

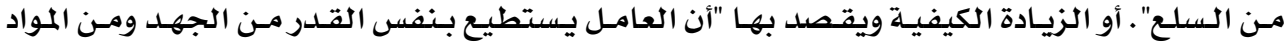

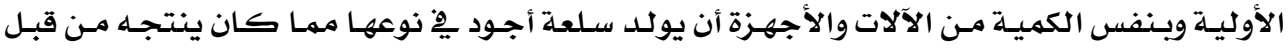

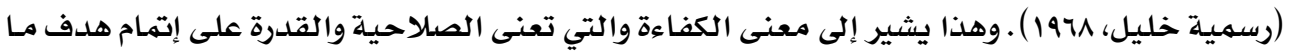




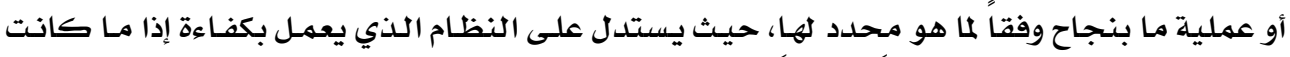

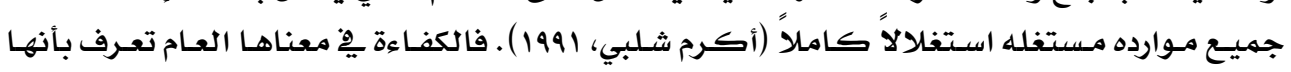

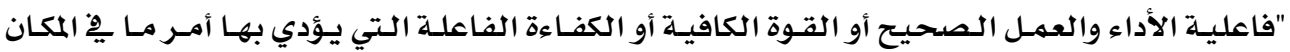

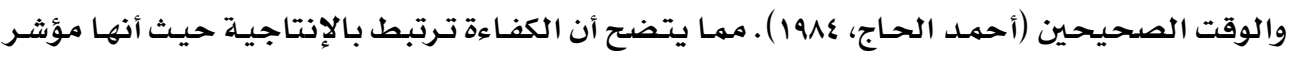

هام على ارتفاع أو انخفاض الإنتاجية (احهية.

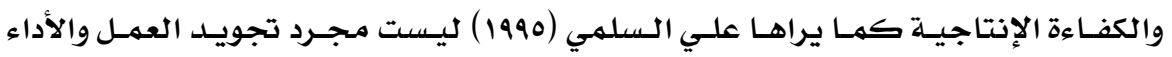

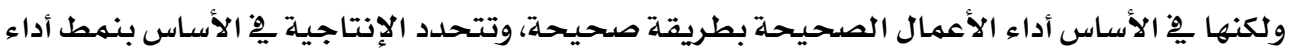

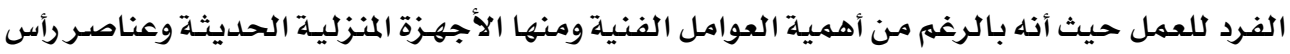

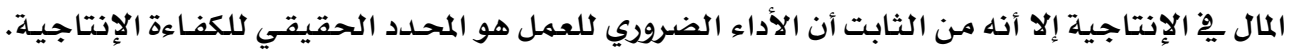

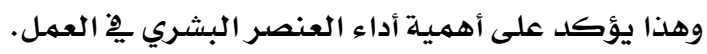
أن الكفاءة الأدائية والإنتاجية تمثل إحـدى القضايا الحيويـة التي تؤثر على معـدلات النهـو التهو

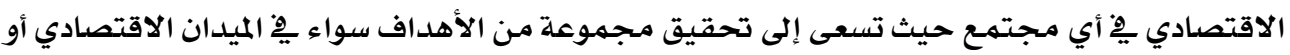

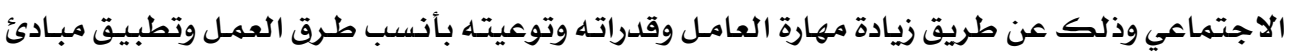

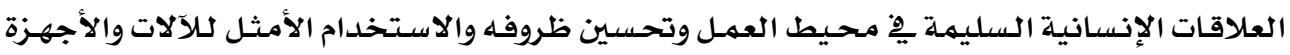

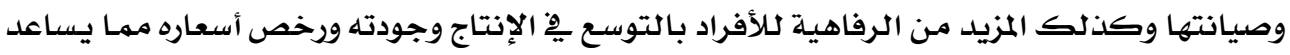

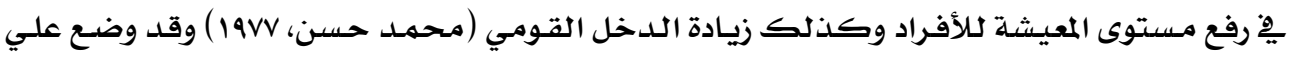

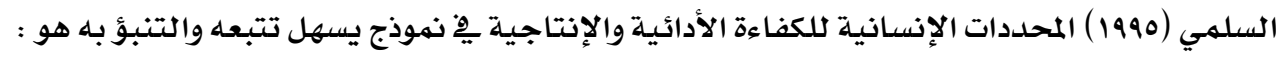

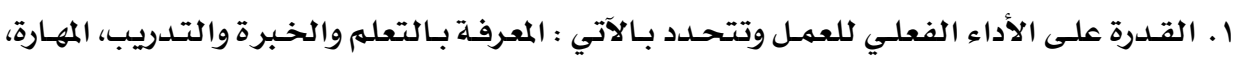

$$
\text { القدرة الشخصية، التكوين النفسي والجسماني. }
$$

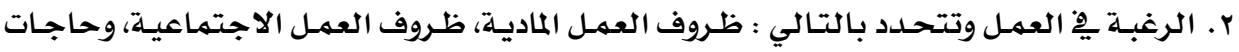

$$
\text { ورغبات الفرد. }
$$

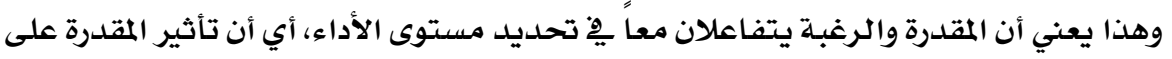

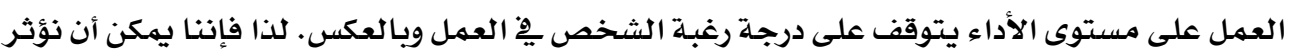

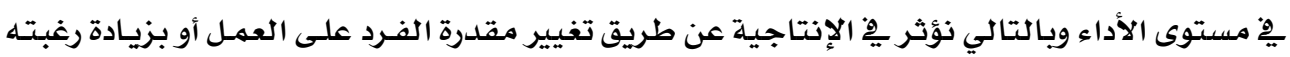

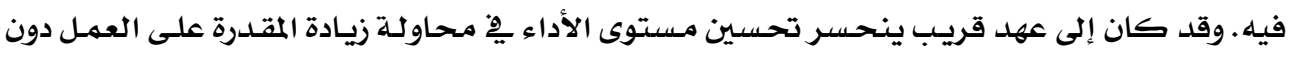

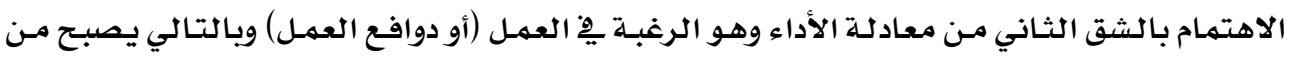

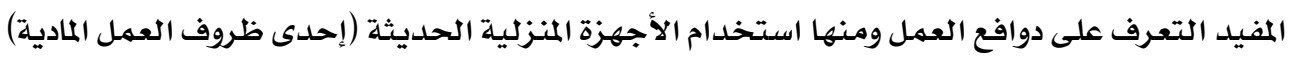

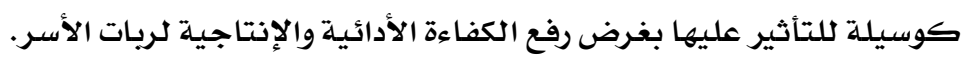

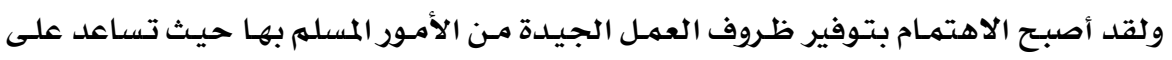

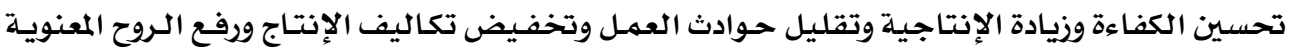

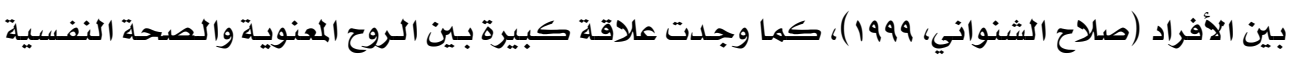

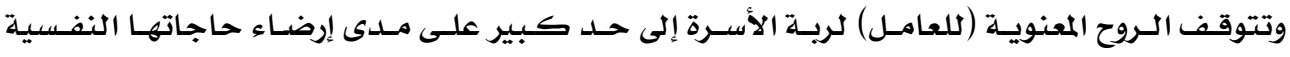


المختلفة وما يحيط بها يِّ محيط عملها من جو مادي ومعنوي مما يساعد يِّ تكوين اتجاهات إيجابية

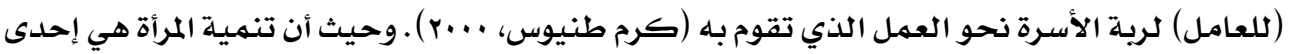

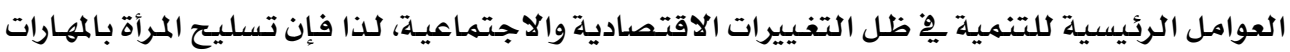

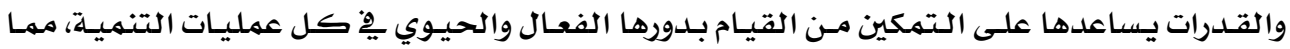

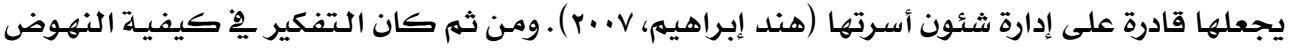

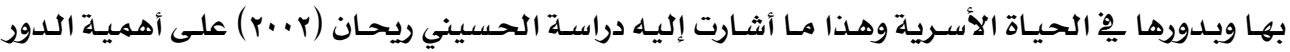

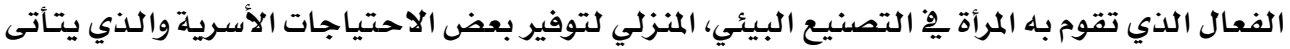

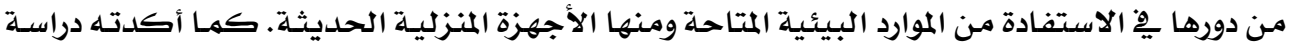

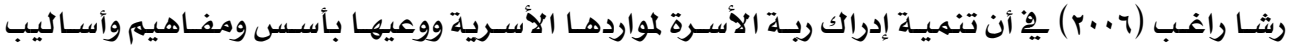

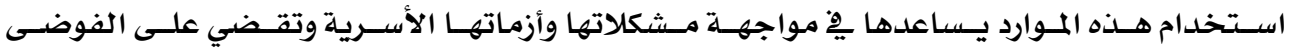
والارتجالية يِّحياتها الأسريية.

فالأجهزة المنزلية تعد من أهم الموارد المادية التي تمتلكهها الأسـرة وتتمثل أهميـة هـذا المورد فِيْ

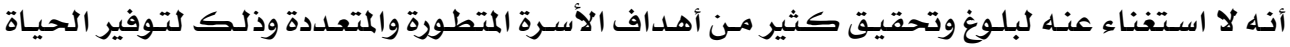

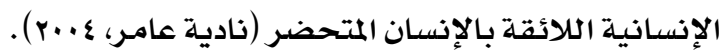
وقد أبرزت العديد من الدراسـات أهميـة مـورد الأجهزة المنزليـة الحديثية بالنسبـة لريـة الأسـرة

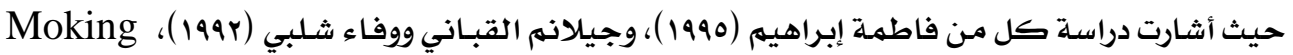

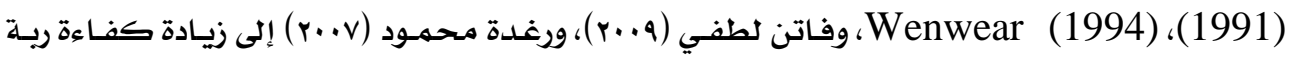

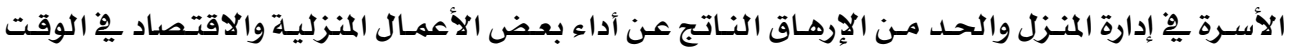

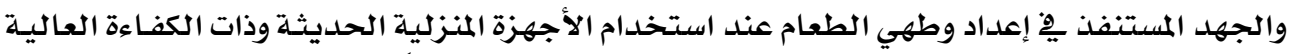
وتيسير الأعباء اليومية المتنوعة سواء البسيطة منها أو الأكثر تعقيداً.

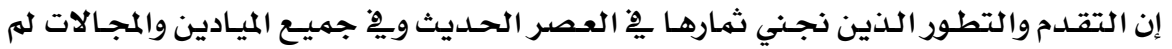

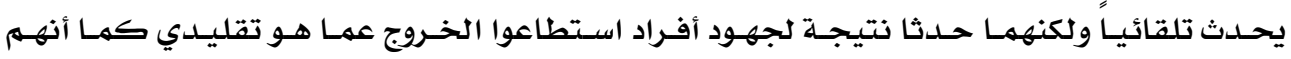

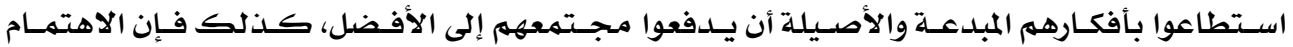

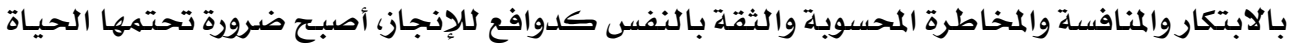

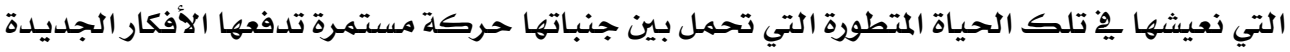

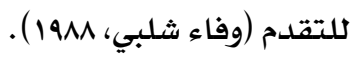

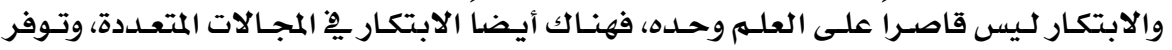

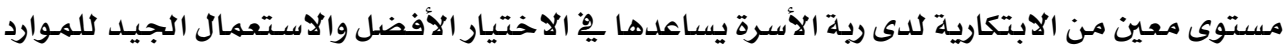

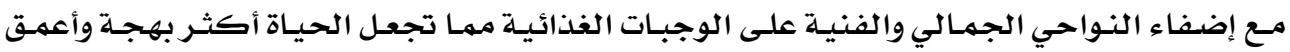

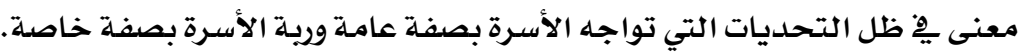

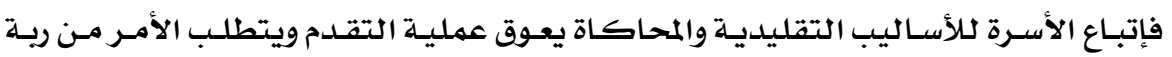

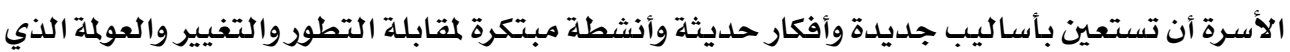




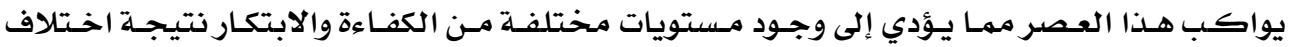

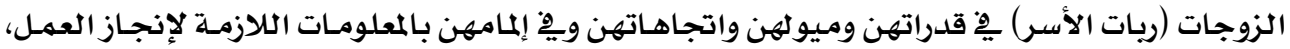
وتباين الظروف الاقتصادية والاجتماعية الاسية للأسرة.

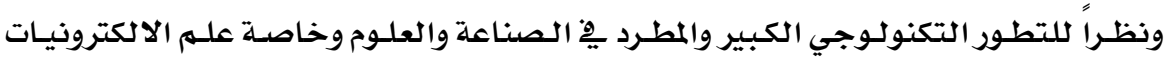

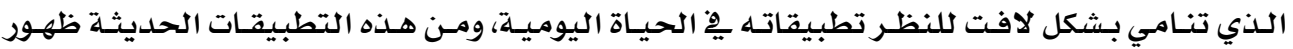

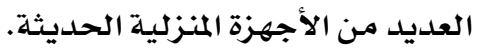

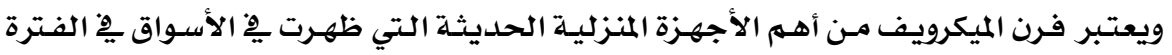

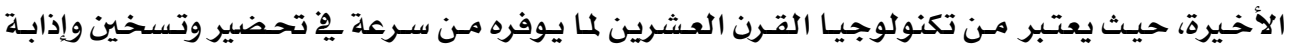

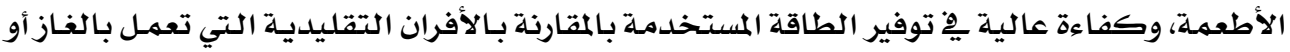

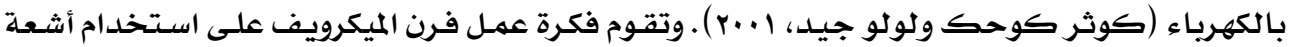

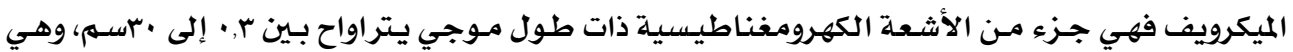

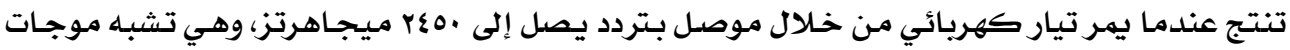

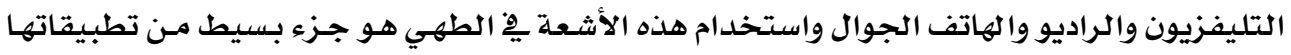
العديدة (Kelly, 2008).

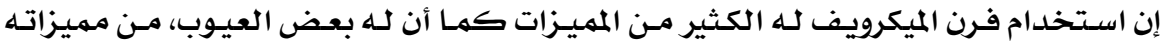

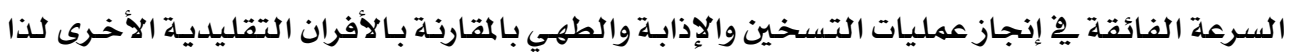

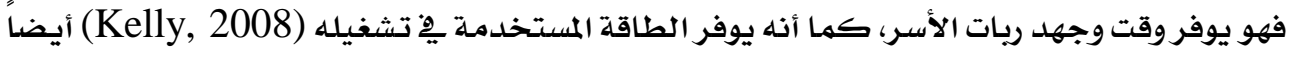

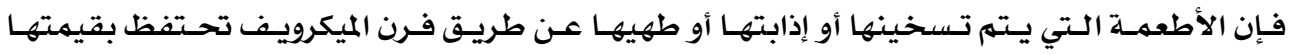

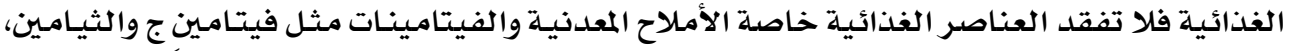

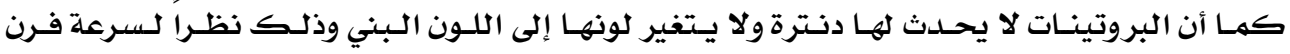

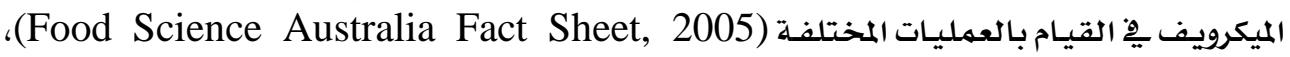

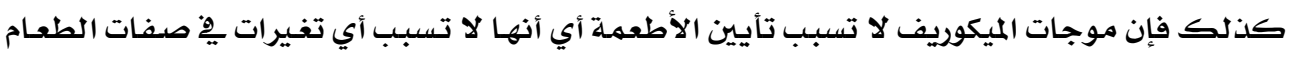

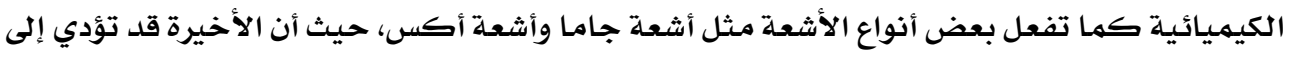

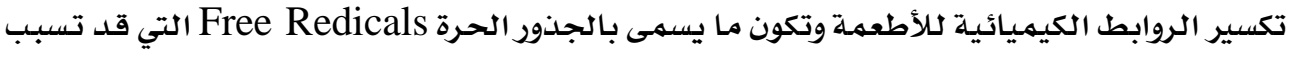

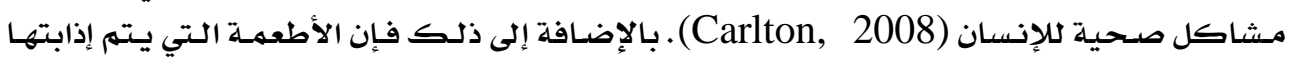

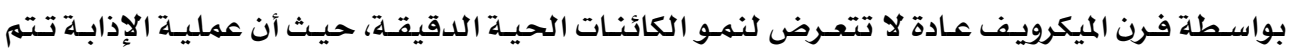

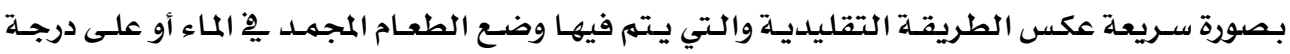

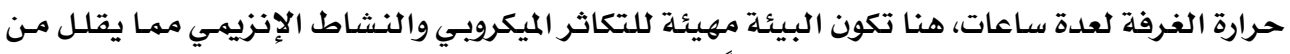

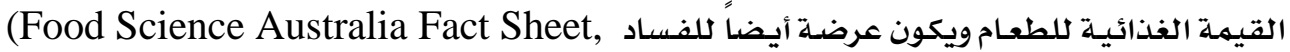

(Margaret and Doris, 2005)، 2005)

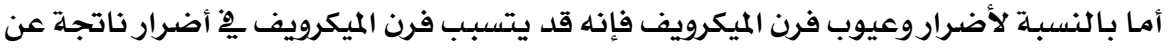

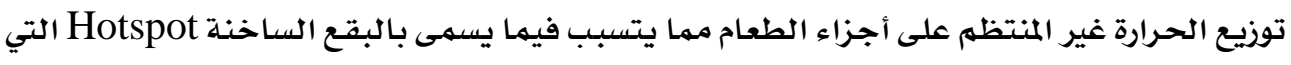




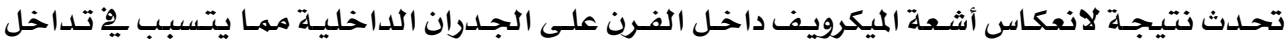

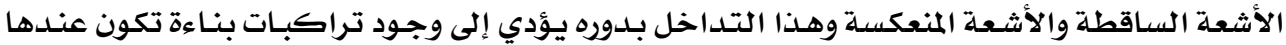

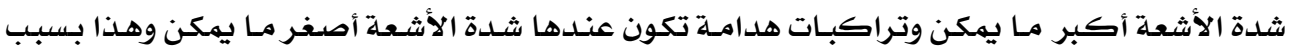

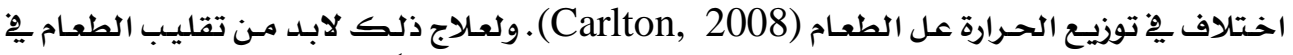

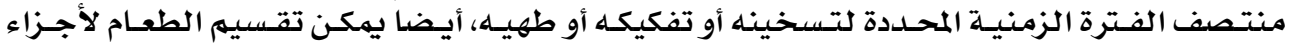

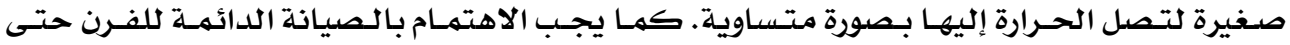

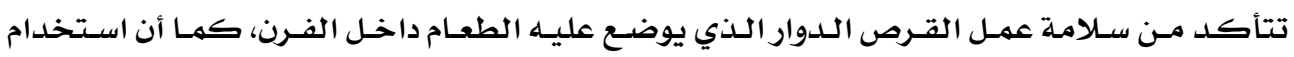

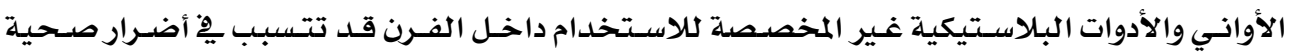

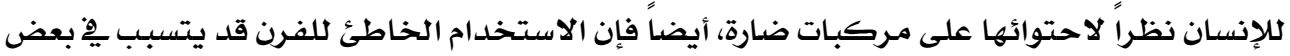

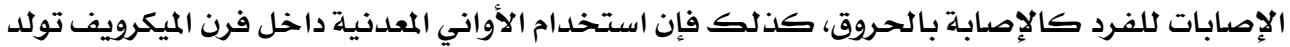

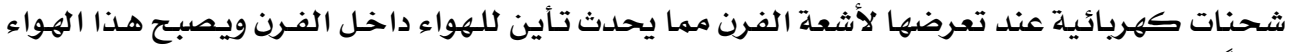

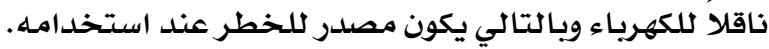

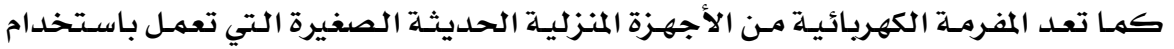

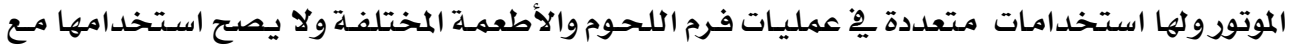

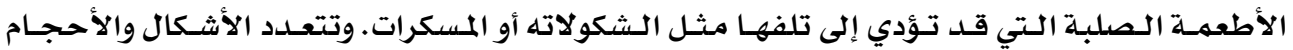

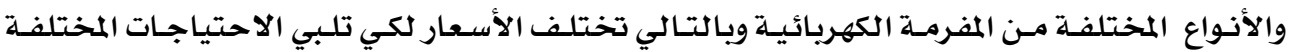

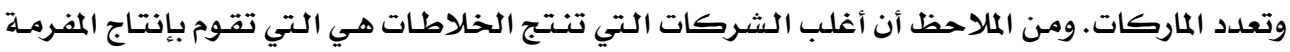

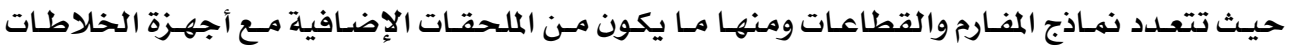

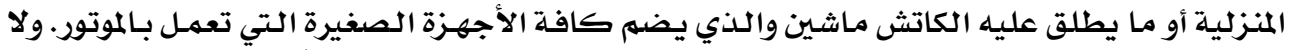

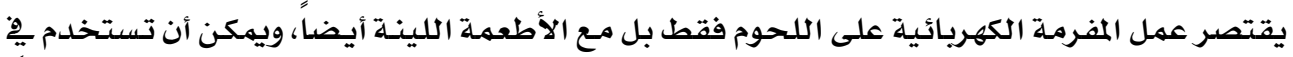

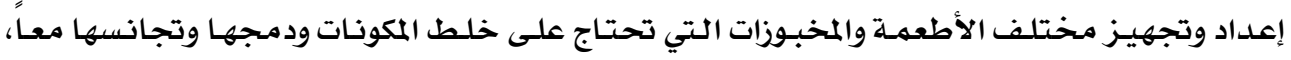

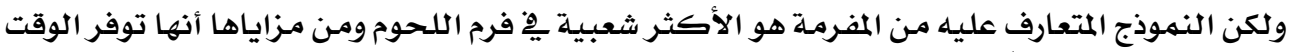

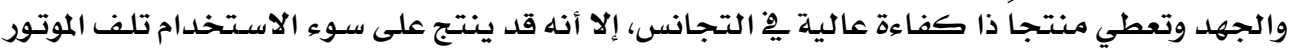

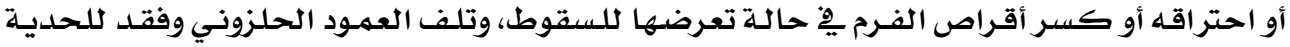

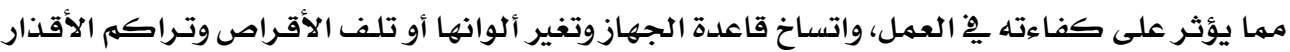

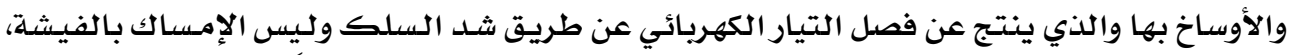

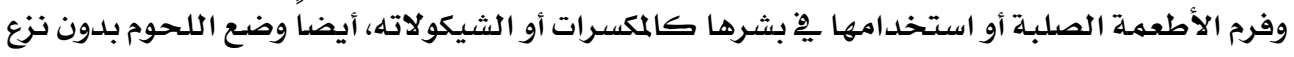

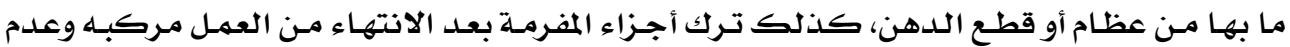

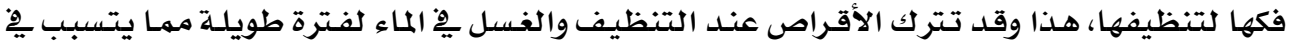

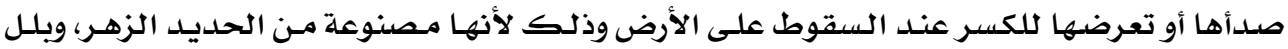

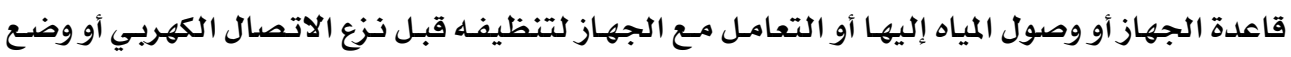

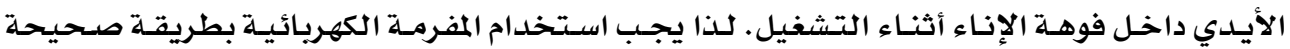
وإتباع طرق العناية والتنظيف والتخزين السليه. (وفاء شلبي وآخرون، V. . r ). 
وكذلك تعتبر المقلاة الكهريائية مـن الأجهزة المنزليـة الحديثة نسبياً ِِِ الاستخداموالتي

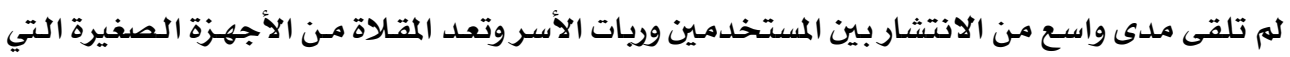

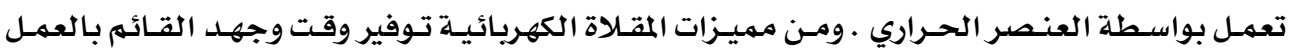

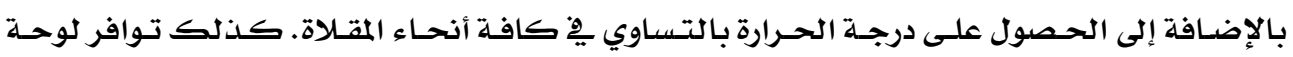

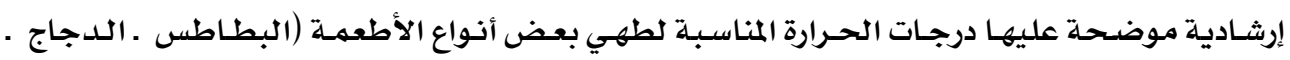

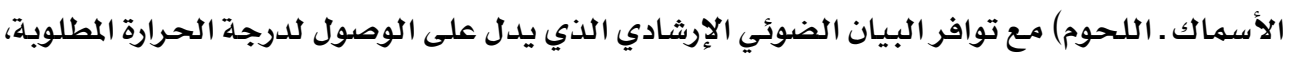

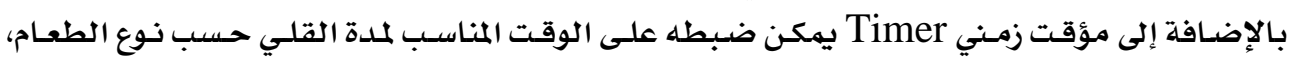

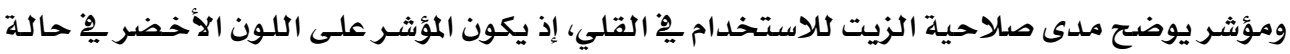

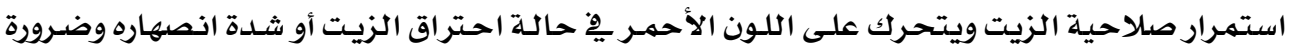

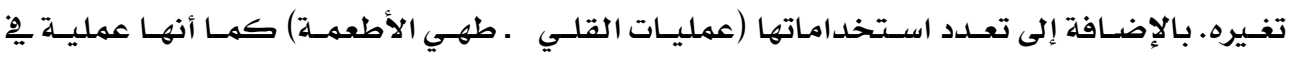

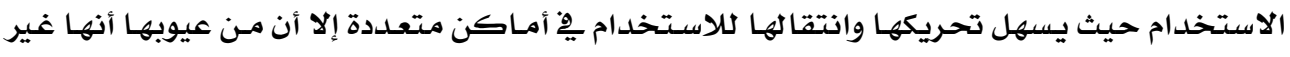

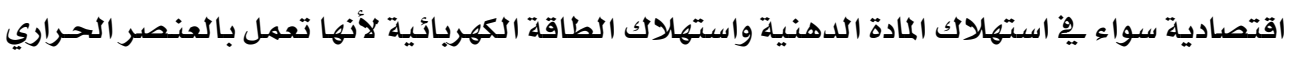

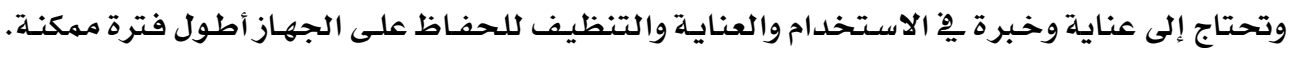

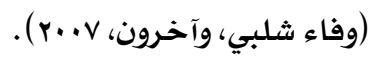

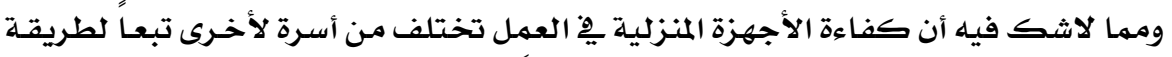

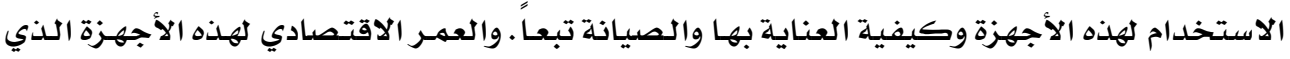

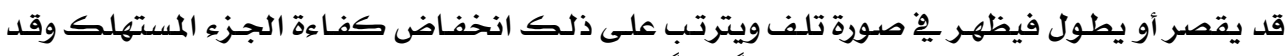

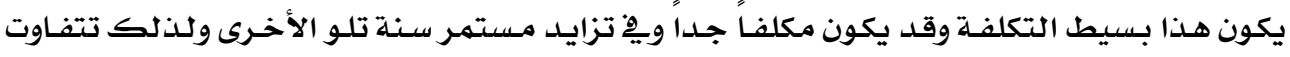

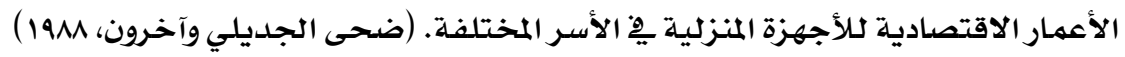

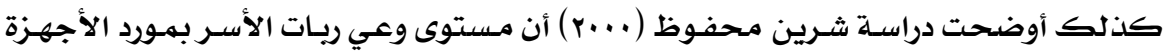

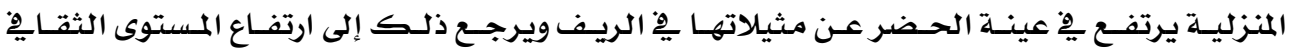

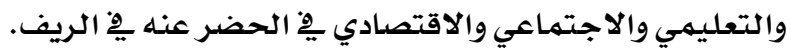

إن رية الأسرة باعتمادها على معلوماتها وخبر اتها وقدراتها يمكنها من حل كل كل مـا يواجهها

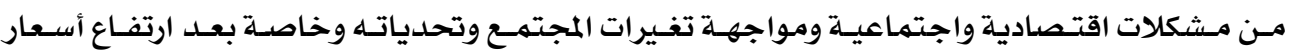

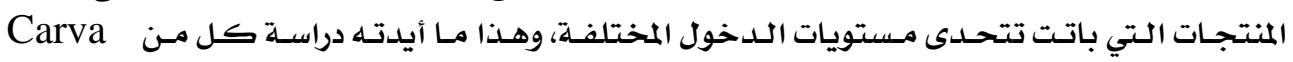
(1996)،ووفاء شلبي (1999) ).

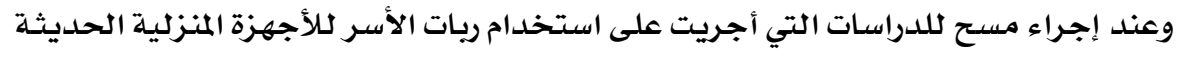

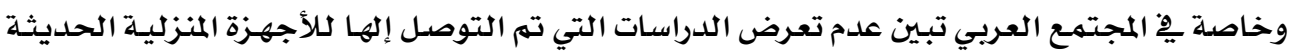

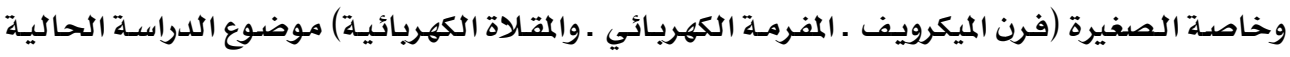
كذلك أثر استخدام الأجهزة المنزلية الحديثة على الكفاءة الأدائية والإنتاجية الكرية لريات الأسر. 


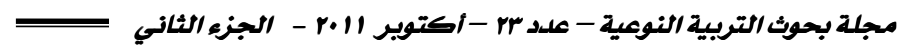

من هنا كان الاهتمام باختيار موضوع البحث حول أثر استخدام ريات الأسر لبعض الأجهزة

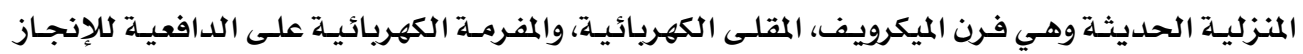

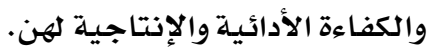

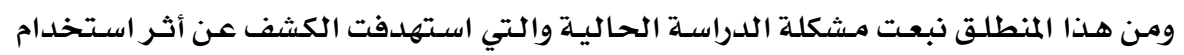

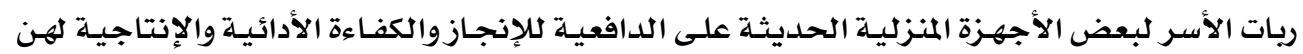

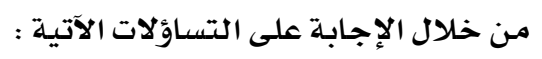

1. ما هي أولويات استخدام ريات الأسـر لبعض الأجهـزة المنزليـة الحديثة (فرن الميكرويف ـ المقلاة

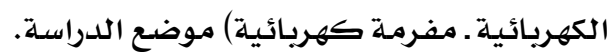

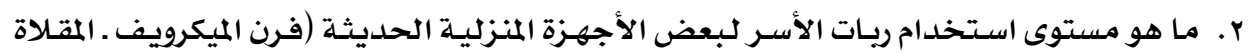

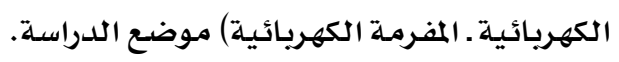

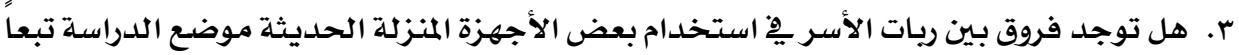

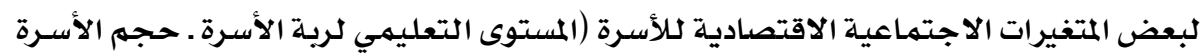

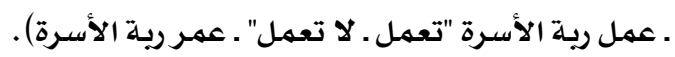

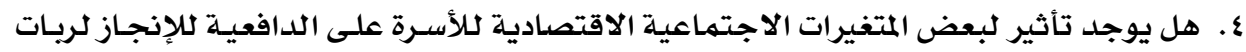
الأسر.

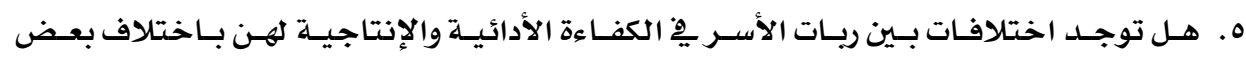

$$
\text { المتغيرات الاجتماعيـة والاقتصادية لـلأسرة. }
$$

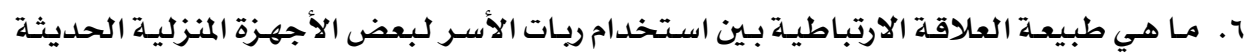

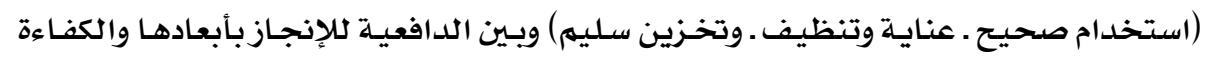

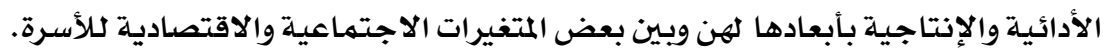

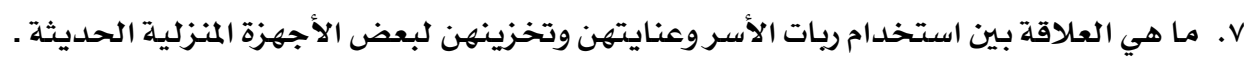

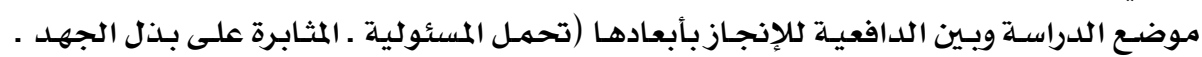

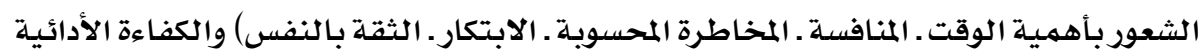

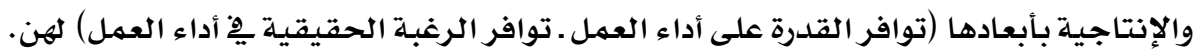

يهـدف البحـث بـصفة أسـاسـية إلى التعـرف على أثر اسـتخدام ريـات الأسـر لبعض الأجهـزة

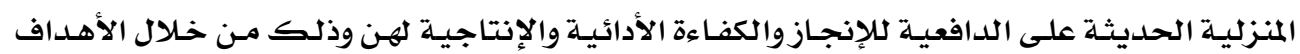
الفرعية التالية : المنزلية الحيثة

ا. التعرف على الأهمية النسبية لأولويـة استخدام ربـات الأسـر لبعض الأجهزة المنزليـة الحديثـة

$$
\text { موضع الدراسة. }
$$

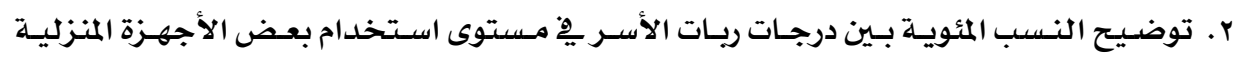
الحديثة موضع الدراسـة. 


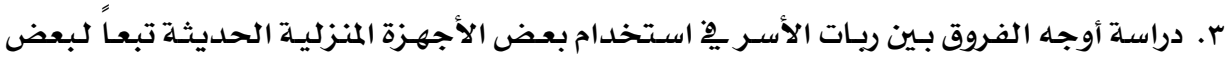

المتغيرات الاجتماعية والاقتصادية لكلأسرة.

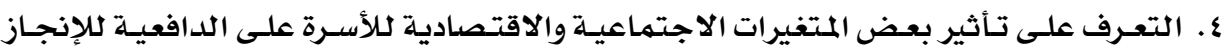

لريات الأسـر.

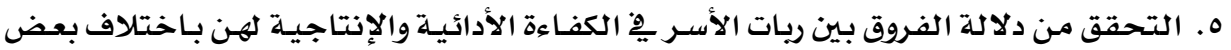

المتغيرات الاجتماعية والاقتصادية لكلأسرة.

7.

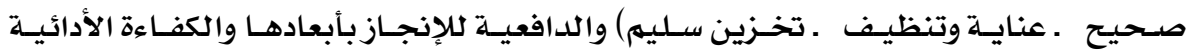

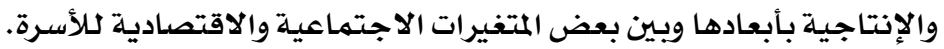

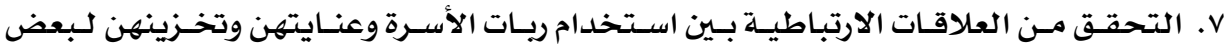

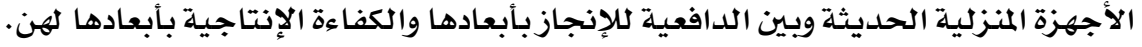

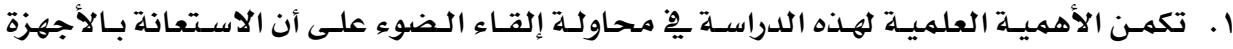

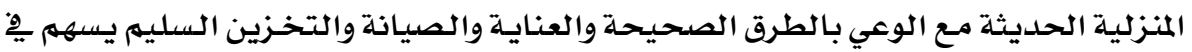

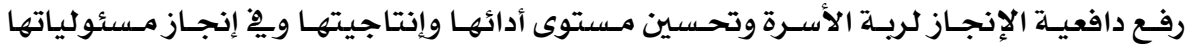

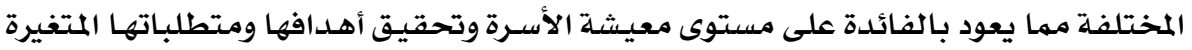
والمتطورة يِ ظل العولمة.

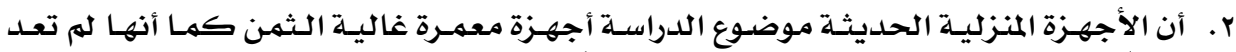

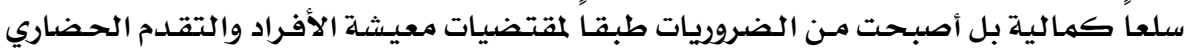

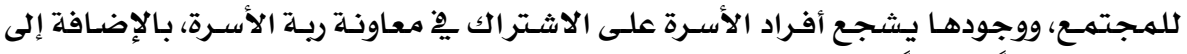

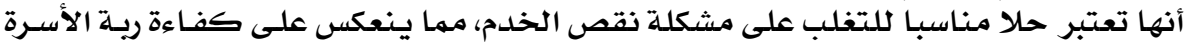

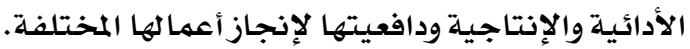

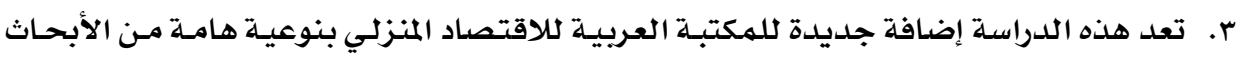

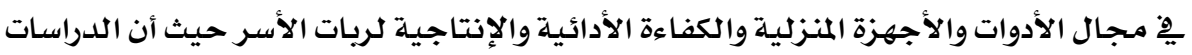

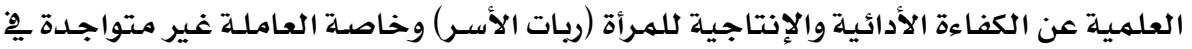

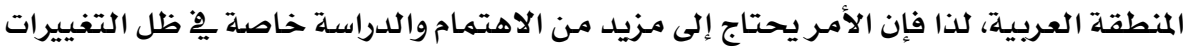

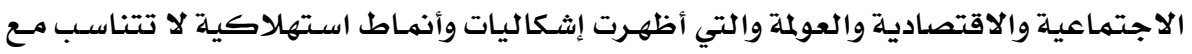

مستوى دخول الأسـر المصرية بشكل عام بالإضافة إلى تعلدد مسئوليات وأعباء المرأة.

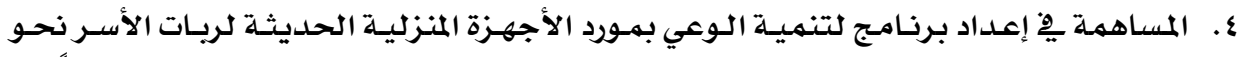

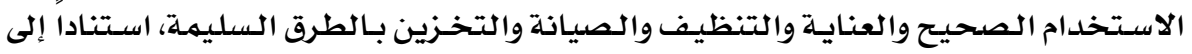

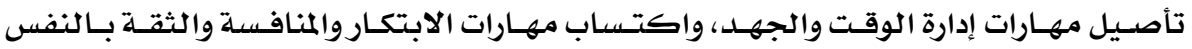

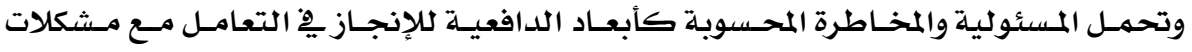

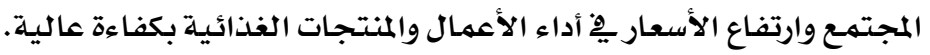




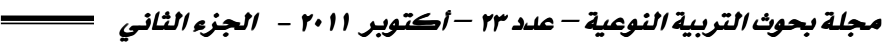

فروض البمث :

ا ـ تختلف الأوزان النسبية لبعض الأجهزة المنزلية الحديثة موضع الدراسة تبعاً لأولوية استخدام

$$
\text { ريات الأسـر لها. }
$$

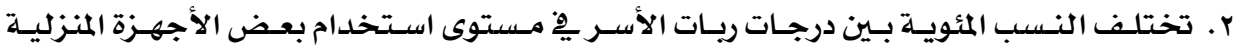

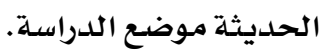

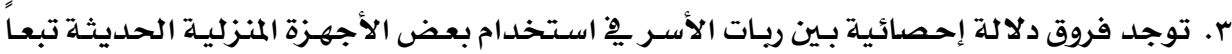

$$
\text { لاختلاف بعض المتغيرات الاجتماعية والاقتصادية للأسرة. }
$$

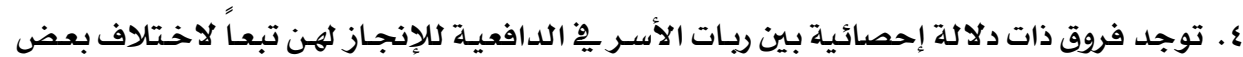

$$
\text { المتغيرات الاجتماعية والاقتصادية للأسرة. }
$$

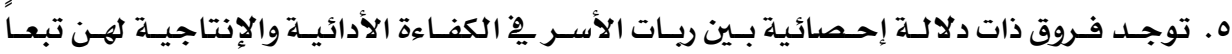

لاختلاف بعض المتغيرات الاجتماعية والاقتصادية للأسرة.

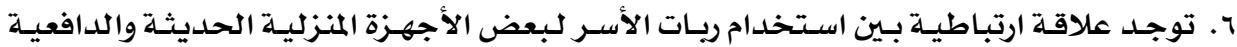

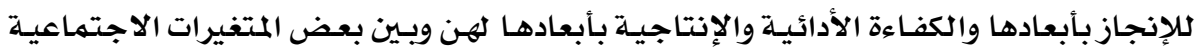

والاقتصادية لكلأسرة.

V. توجد علاقة ارتباطيـة بـين استخدام ريـات الأسـرووعنـايتهن وتخزينهن لبعض الأجهزة المنزليـة

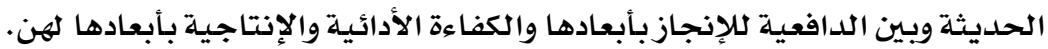

\section{الصططات والتعريفات الإجرائية :}

\section{Modern House Hold Equipment : الأجهزة المنزلية الحديثة والهرهاته :}

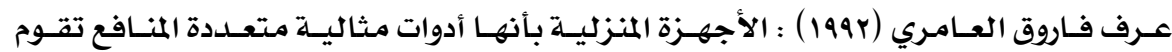

بالأعمال المنزلية الخفيفة والثقيلة وبذلك فهي تساعد يو تسهيل كثير من الواجبات المنزلية.

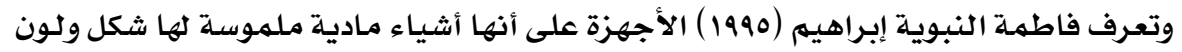

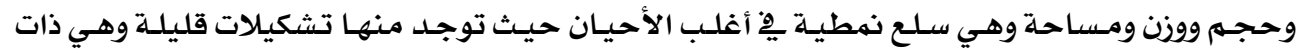

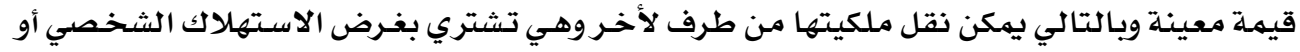

$$
\text { على مستوى الأسرة. }
$$

كما تعرف وفاء شلبي والطاهرة العدوي (1999) الأجهزة المنزلية هي الأجهزة المنتجة بهدف

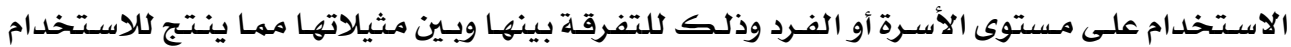

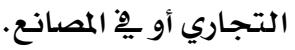

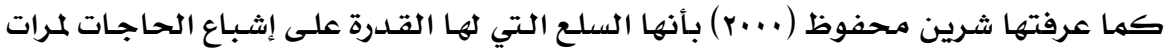

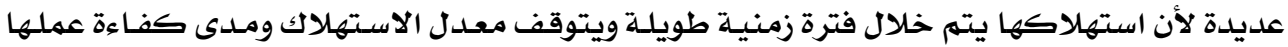

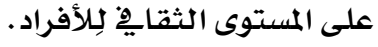




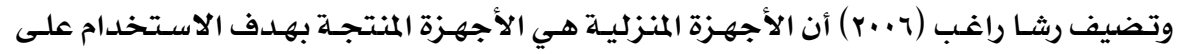

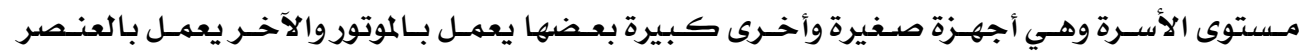
الحراري.

\section{التعريف الإجرائي لاستخدام الأجهزة المنزلية الحديثة يْ هذه الدراسة :}

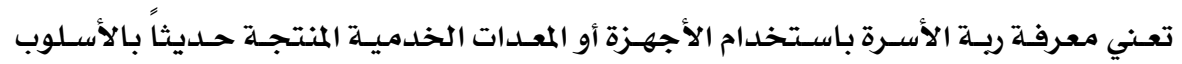

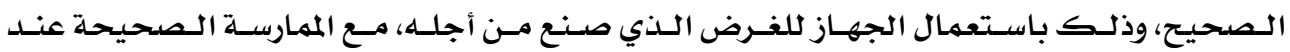

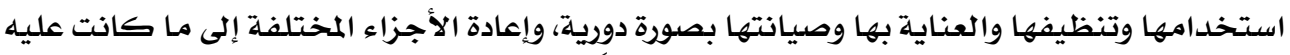

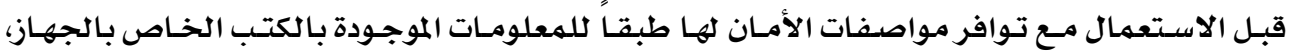

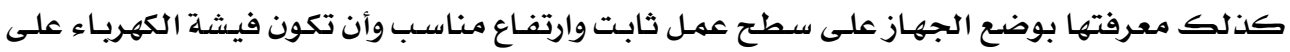

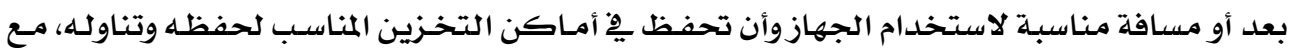

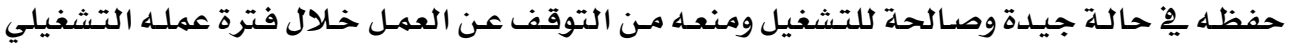

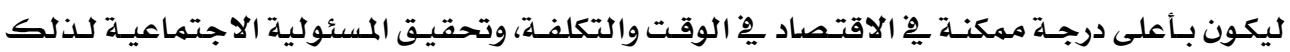

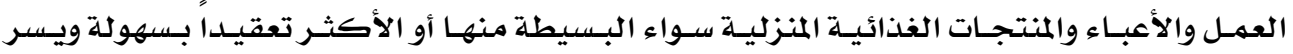

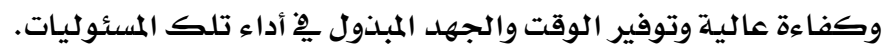
والأجهزة المنزلية الحديثة المستخدمة يِّهذ هذا البحث هي : فرن الميكرويف ـ المفرمة الكهريائية . المقلاة الكهريائية. فرن الميكرويف : هو جهاز من الأجهزة المنزلية الحلديثة يعرف بالموقد الالكتروني، وهو عبـارة

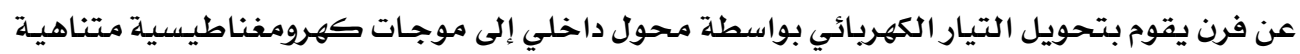

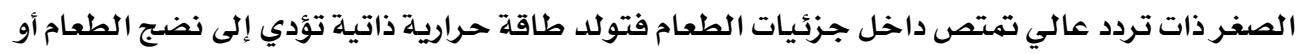

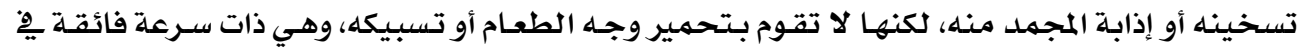
الأداء. (Carlton, 2000) المفرمـة الكهريائية : تعد من الأجهزة المنزلية الحديثـة الصغيرة التي تعهل استخدلـام الموتور

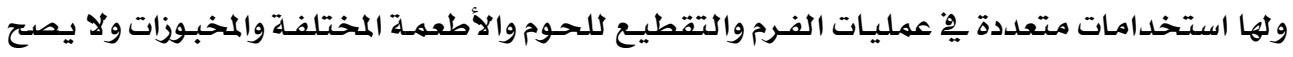

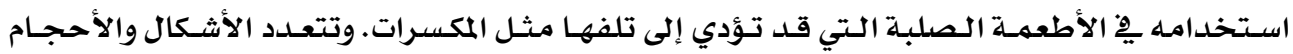

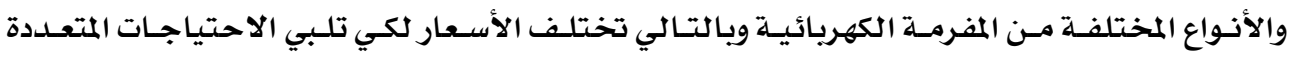

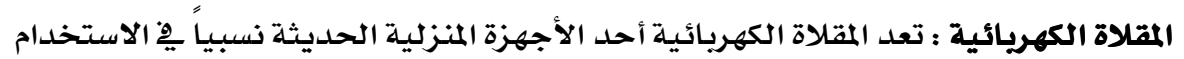

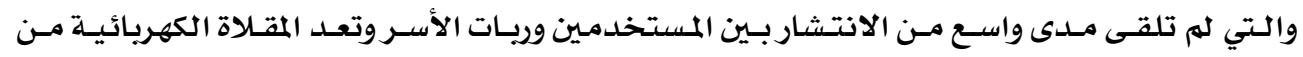

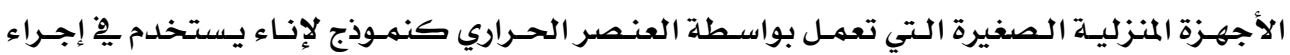

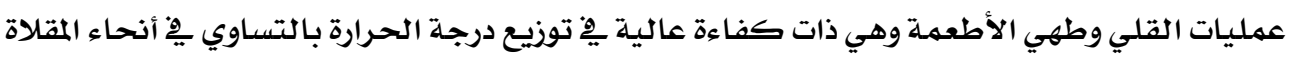

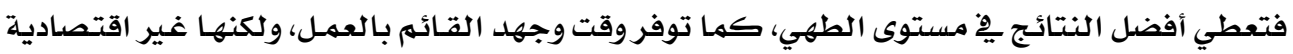


مجلة بحوث التربية النوعية - علد سr - أكتوبر ll - - الجزء الثاني

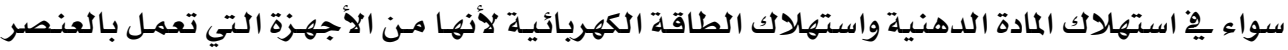
الحراري، وتحتاج إلى عناية وخبرة يخ الاستخدام للحفاظ على الجهاز أطول فترة مهكنة.

\section{Achievement Motivation : الدافعية للإنجاز الحاز}

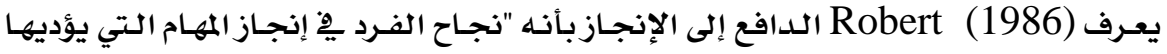

$$
\text { والسعي نحو تحقيق الأهداف. }
$$

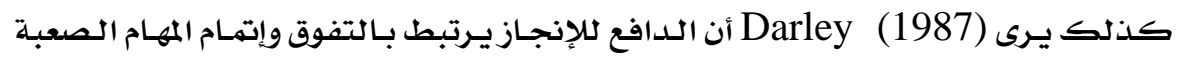

$$
\text { وبلوغ معايير عالية وتخطي الآخرين والتفوق عليهم. }
$$

بينهـا تعـرف وفـاء شـلبي (1999) الدافعيـة لإِنجـاز للزوجـة بـأنها حالـة داخليـة لـدى الزوجـة لتتشيط سلوكها وتوجيهه نحو هدف، وهي القـوة الدافعـة الـتي تـففحها لإنجـاز أعماكها وبـذل الطاقـة والنشاط كما أنها توجه سلوكها وتجعلها تختـار الطـرق التي تؤدي إلى إثـبـاع حـاجـات ورغبـات أفراد

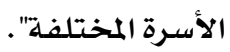

ويعرفها صـلاح مـراد وأحمد عبد الخالق (.... ( ب) بأنها "رغبـة أو ميـل إلى الأداء السـريع للههام والإتقان يِ العمل واختيار أفضل الطرق للإنجاز، وهو يحث الفرد على التنـافس وإتقان الأداء والتميـز

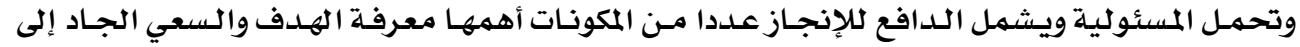
تحقيق وجودة الأداء وتعديل المساروالضبط الذاتهي. وتعـرف الدافعيـة كلإنجــاز إجـرائيـاً بـأنهـا : "القــوة الـتي تـدفع ربـة الأسـرة إلى إنجــاز جميـع

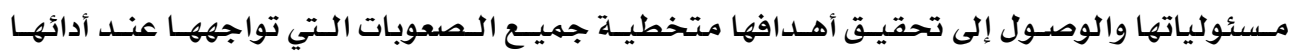
لأعما لها لتحقيق غاياتها وأهداف وحاجات أفراد الأسـرة، وتشهل الأبعاد الآتيـة : ا . تحمل المسئولية : هو تحمل ريسة الأسـرة لنتـائج قراراتها وأعما لها والاعتمهاد على الذات، وقدرة

اتخخاذ التقرارات. ץ. المثابرة على بذل الجهد : إصـرارواستمـرار ريـة الأسرة على أداء أعما لها ومسئولياتها على الرغهم من الصعوبات التي تواجهها. r. الشعور بأهمية الوقت : تفهم ريـة الأسـرة لأهميـة الوقت، وحسـن اسـفادتها مـن الوقت لأقصىى درجة مهـكنة. ع. المنافسة : هي تحـدي الظروف والصعوبـات المحيطـة وخلق روح جديدة مـن التحهدي والحمـاس لمواصلة الحياة. ه. المخاطرة المحسوبهة : وهي تعني عدم تردد ربـة الأسرة للدخول يِّة منتجـات جديدة عليها وذلك بعد قيامها بلدراستها جيدا وحسـاب احتهالات نجاحها قبل الإقدام على تنفيذها . 7. الابتكسار : هـي محاولـة ريسة الأسـرة لاكتشـاف طـرق وأسـاليب جديـدة للتغلسب على المشكلات والصعوبات وإنتاج منتتج ذا طابـع خاص بها. 
V. الثقة بالنفس : وتعني امتلاكك رية الأسرة لـلإرادة القويـة التي تؤهلها لإنجـاز أعما لها دون تردد

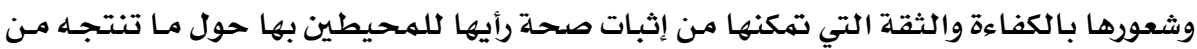

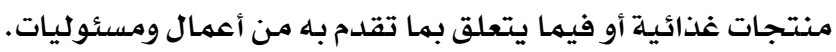

\section{الكفاءة الأدائية والإتتاجية :}

\section{Competency : مفهوم الكفاءة}

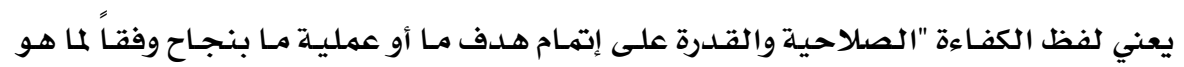

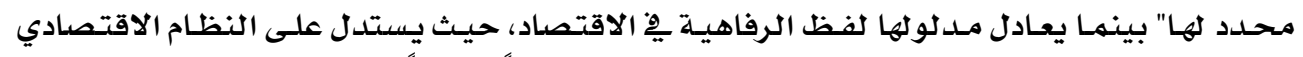

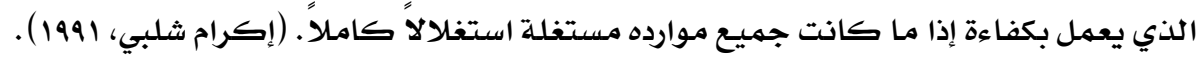

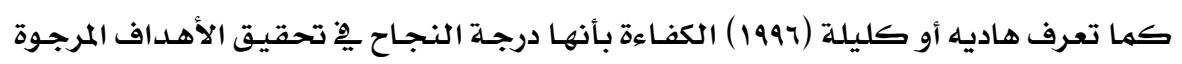
مهما تكن هذه الأهداف.

\section{Performance : مفهوم الأداء} غالباً ما يحدث لبس وتداخل البداء : بين الأداء والجهد، فالجهل يشير إلى الطاقة المبذولة، أمـا الأداء

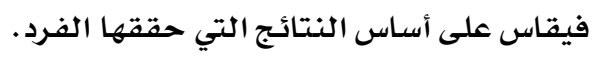

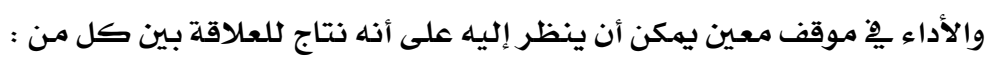

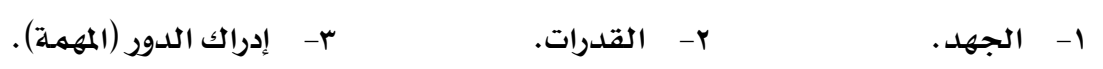

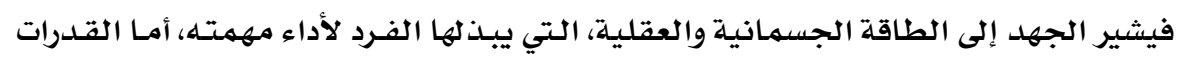

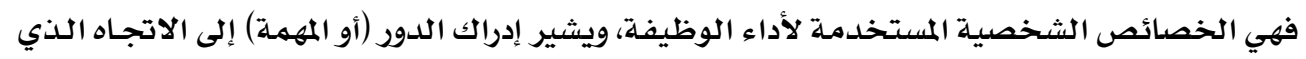

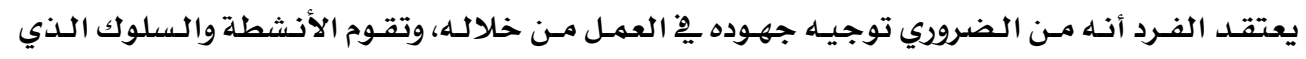

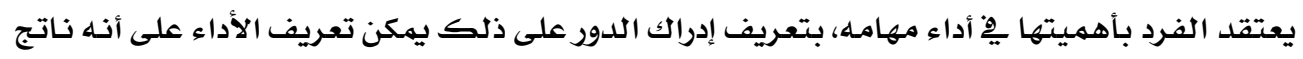

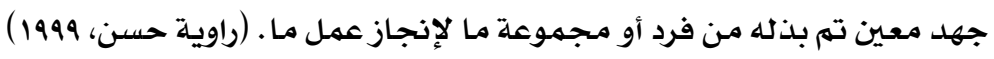

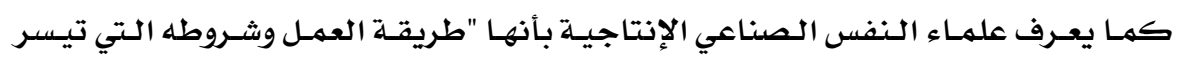

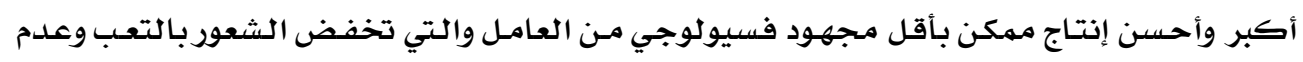

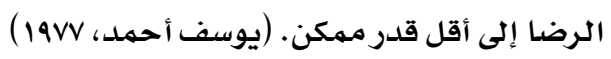

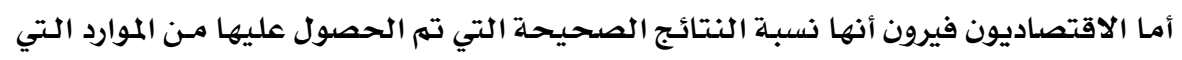

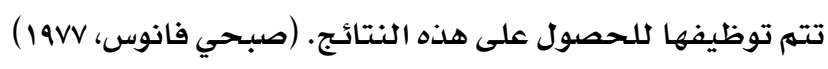

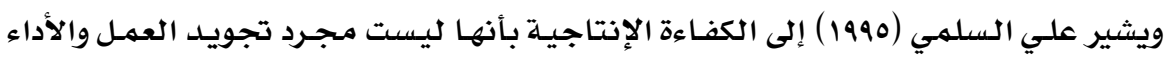

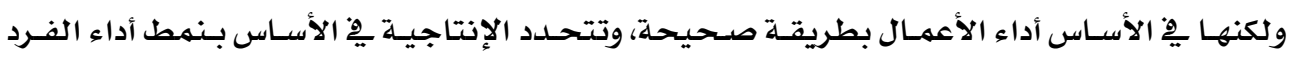

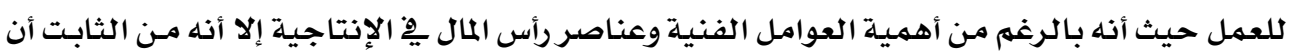

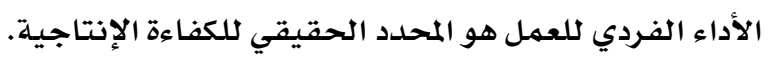

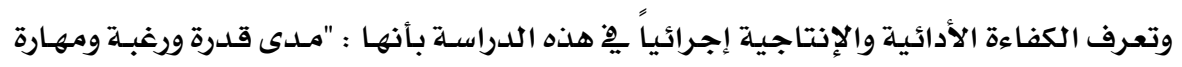

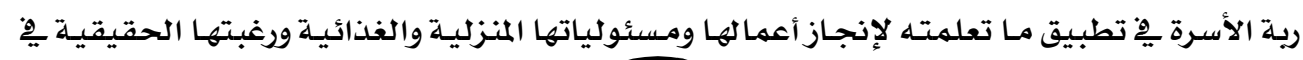


مجلة بحوث التربية النوعية - علد سr - أكتوبر ll - - الجزء الثاني

الاسـتمرار فيـه وبـذل أقصى طاقاتها وإمكاناتها باسـتخدام المـوارد الماديسة المتاحسة (الأجهـزة المنزليسة

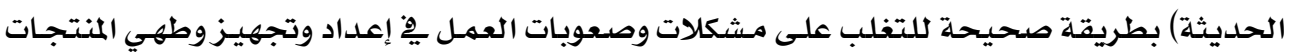

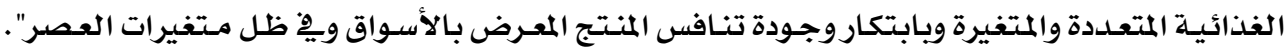
وتشمل الأبعاد التالية :

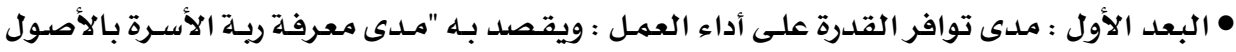

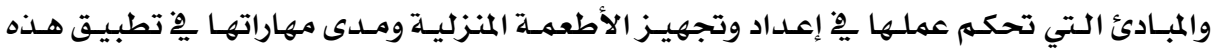
المبادئ للوصول إلى إتمام وإنجاز العمل بالشكل المطلوب وتتحلد العهد القدرة على أداء العمل بالآتي :

$$
\text { 1- المعرفة. }
$$

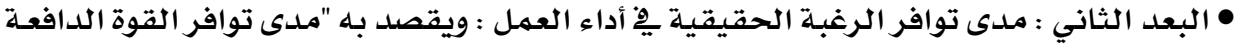

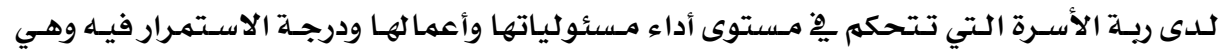

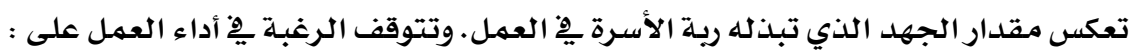

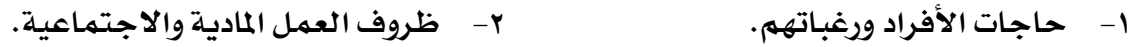

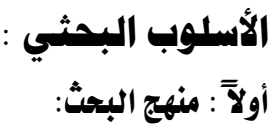

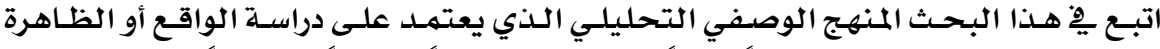

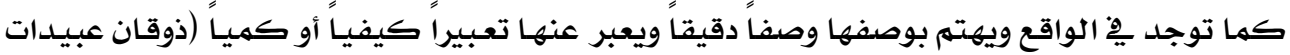

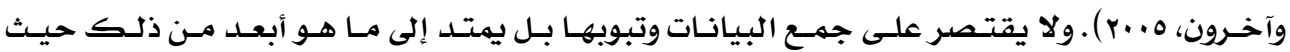

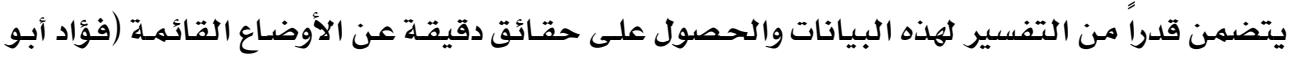

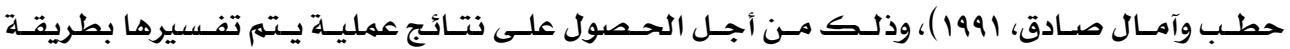

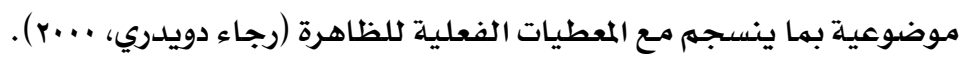
ثانياً : حلدود البحث : مئة بهان

$$
\begin{aligned}
& \text { تتمثل حدود البحث فيما يلي : } \\
& \text { عينة البحث (الحدود البشرية) : }
\end{aligned}
$$

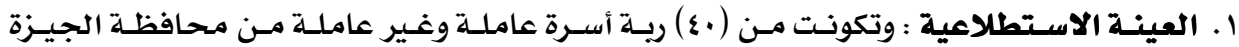

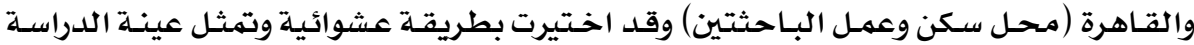

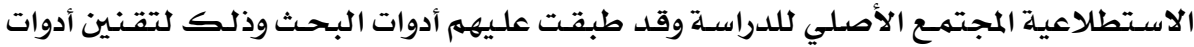
البحث.

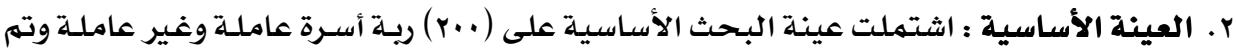

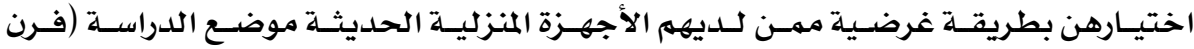

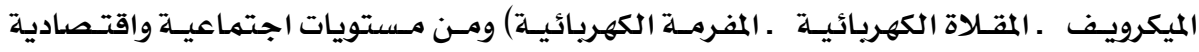

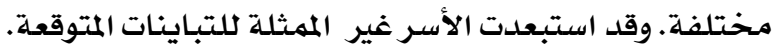




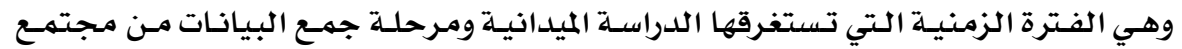

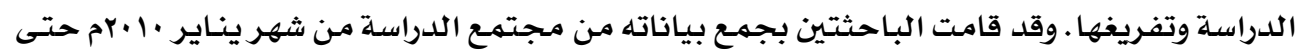

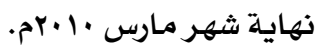

الحدود المكانية الجفرافية :

حددت محافظة الجيزة والقاهرة كمجال جغرابِّه للدراسلةِ.

ثالثاً : أدوات البحث : (إعلداد الباحثتين)

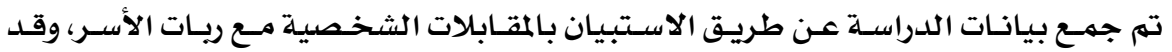

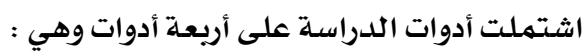

ا- استمارة البيانات العامـة :

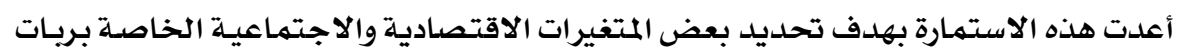

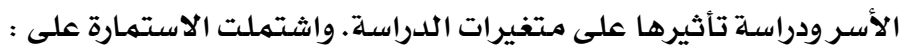

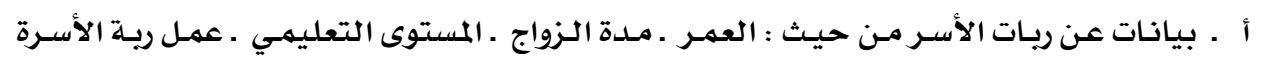

(تعمل لا تعمل) . (تئات عن وبات الاتل

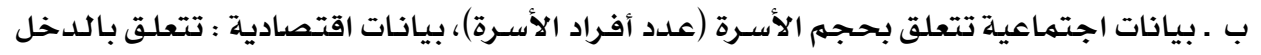

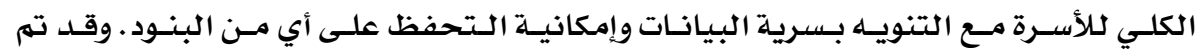

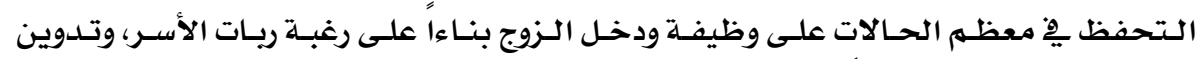

$$
\text { الدخل الكلي لكلأسرة تقريباً. }
$$

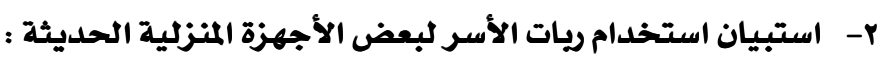

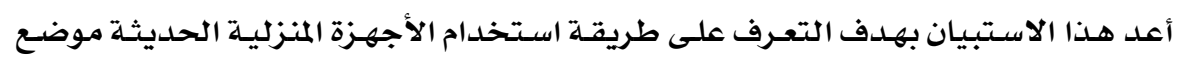

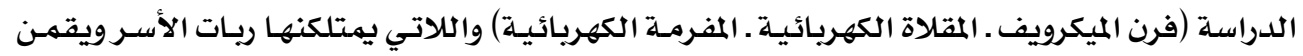

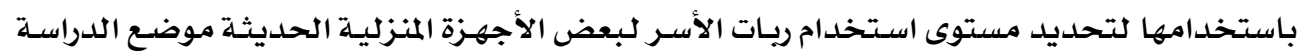

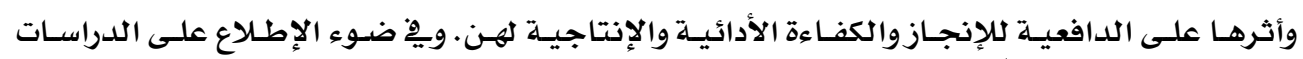

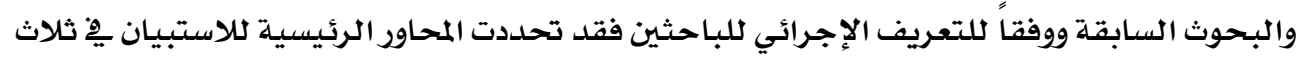
محاور هي :

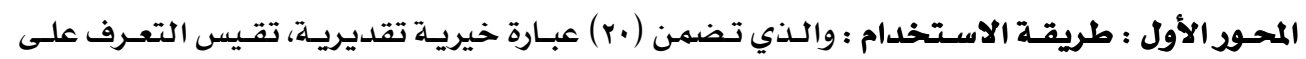

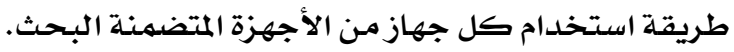

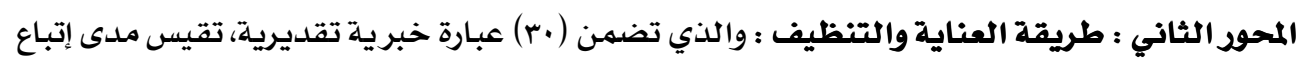

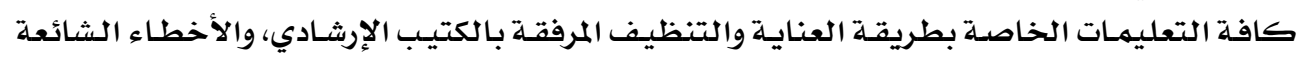

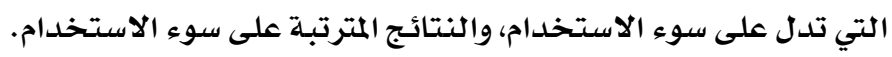


المحور الثالث : طريقة والصيانة : وتضمن ( بr) عبارة خبرية تقديرية تقيس مدىى إتباع طرق التخزين

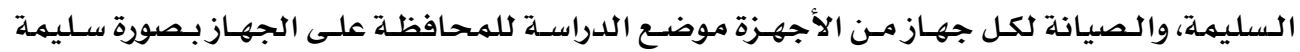

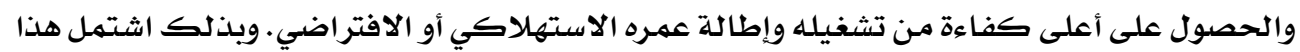

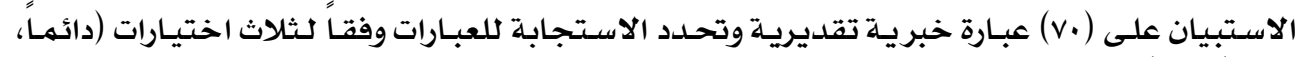

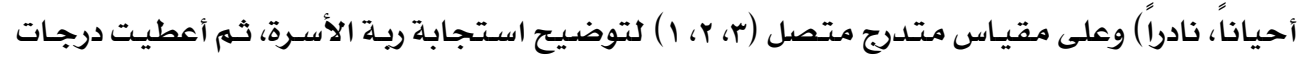

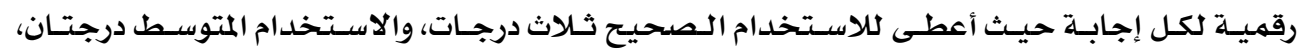

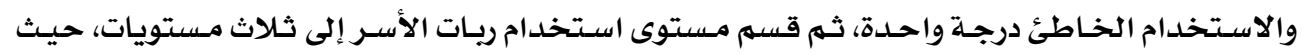

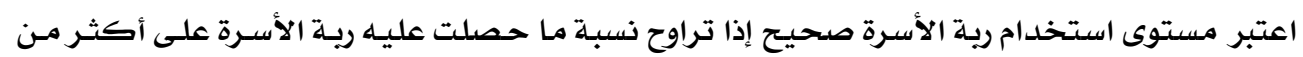

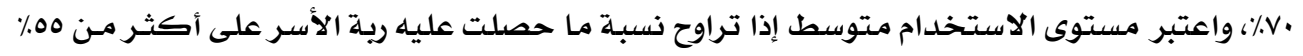

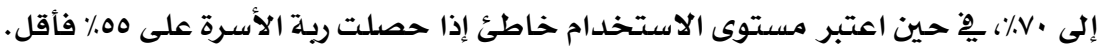

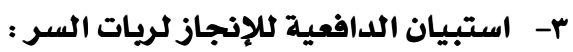

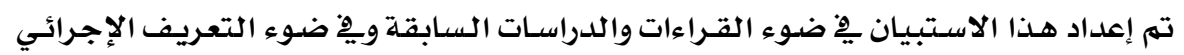

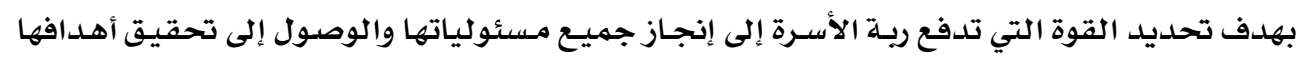

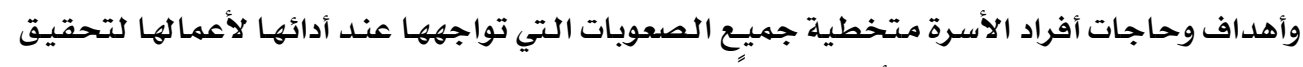

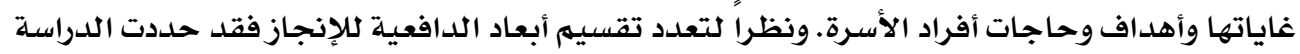

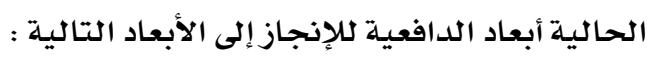

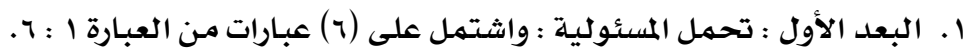

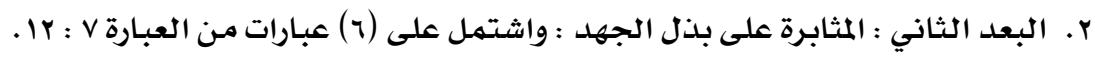

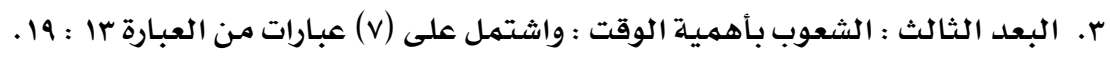

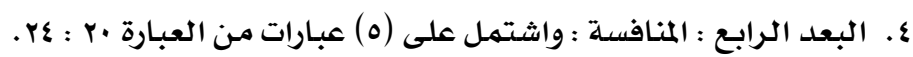

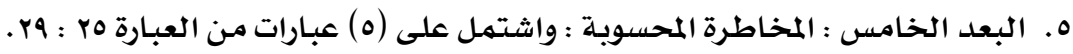

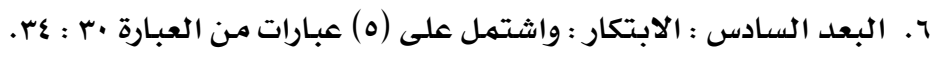

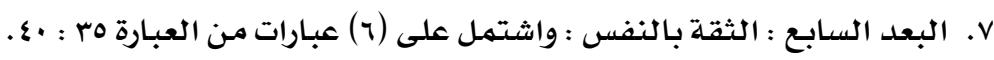

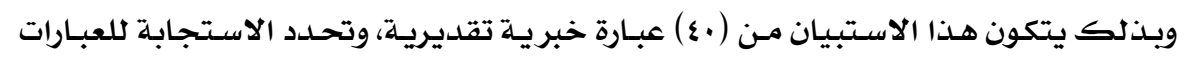

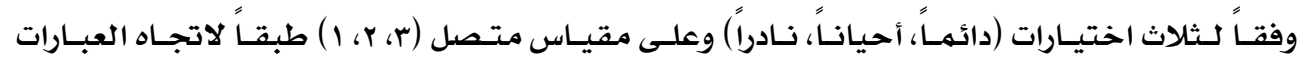

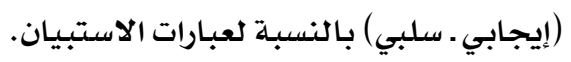

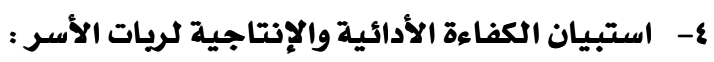

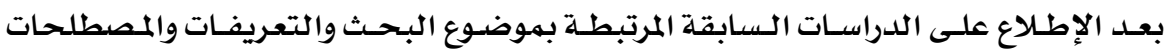

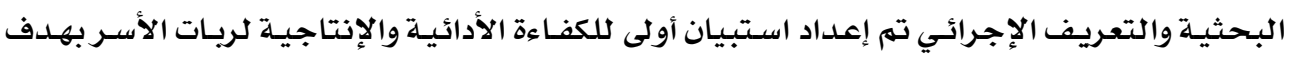

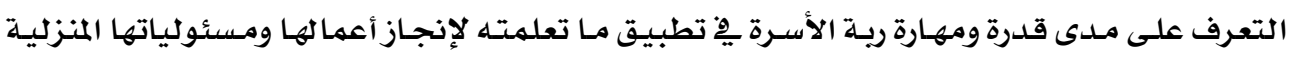

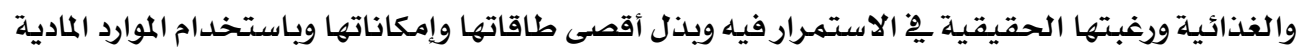

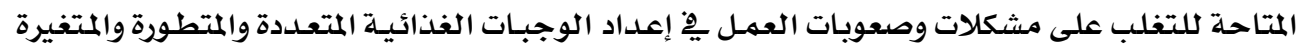




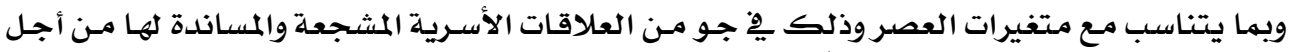

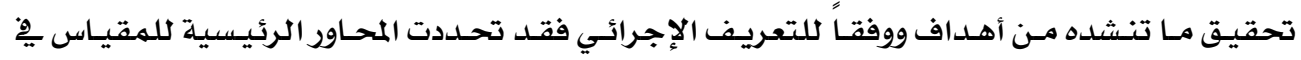

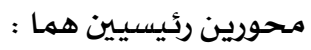

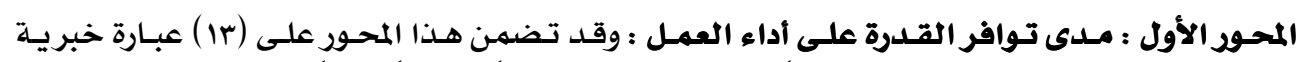

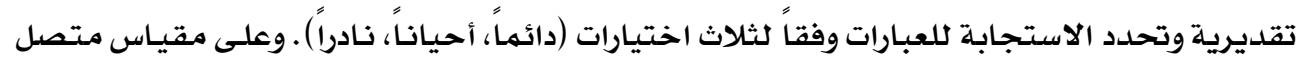

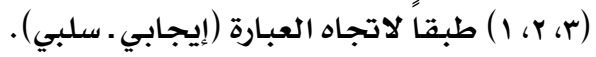

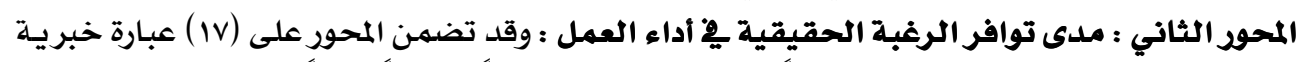

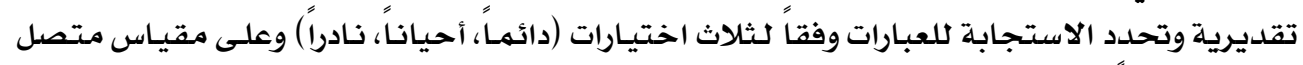

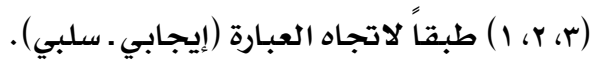

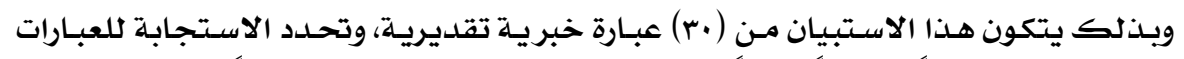

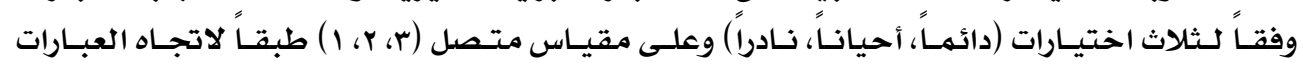

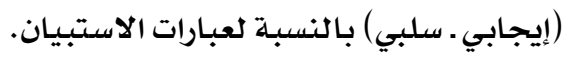

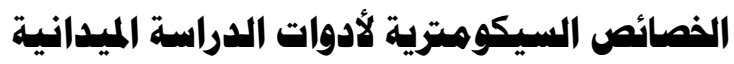

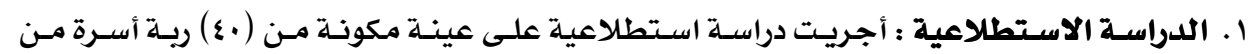

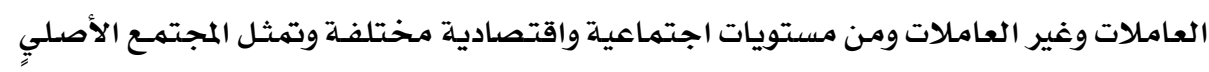

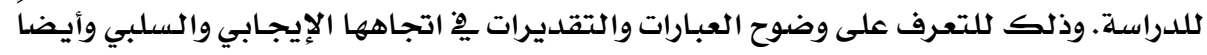

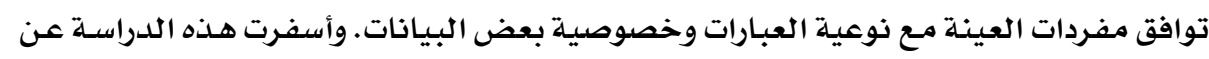

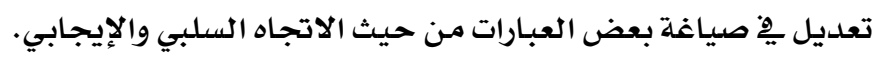

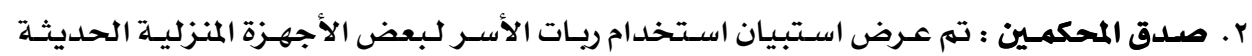

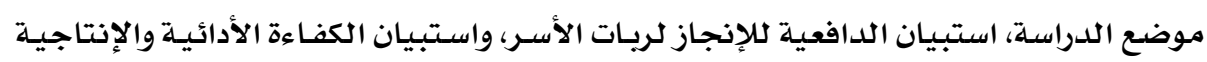

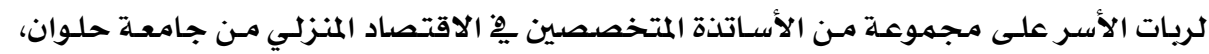

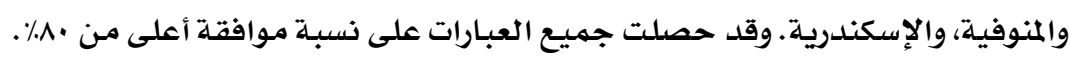

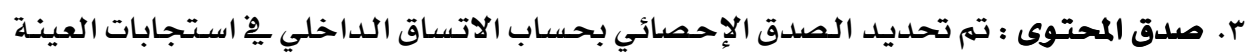

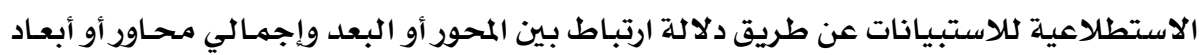

الاستبيان.

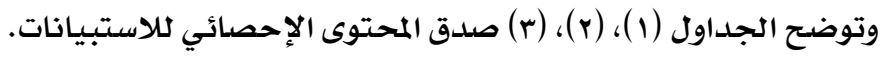

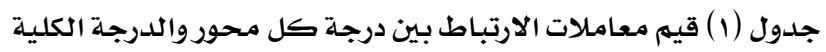

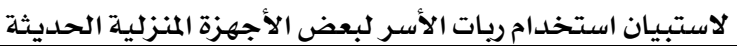

\begin{tabular}{|c|c|c|}
\hline 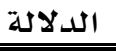 & الارتباط & استخدام بعض الأجهزة المنزلية الحديثة \\
\hline$\cdot, \cdot 1$ & $\cdot, 9 \cdot r$ & المحور الأول : طريقة الاستخدام المثلى \\
\hline$\cdot, \cdot 1$ & $\cdot, \mathrm{VVY}$ & المحور الثاني : طريقة العناية والتنظيف \\
\hline$\cdot, \cdot 1$ & $\cdot, 117$ & المحور الثالث : طريقة التخزين السليم والصيانة \\
\hline
\end{tabular}




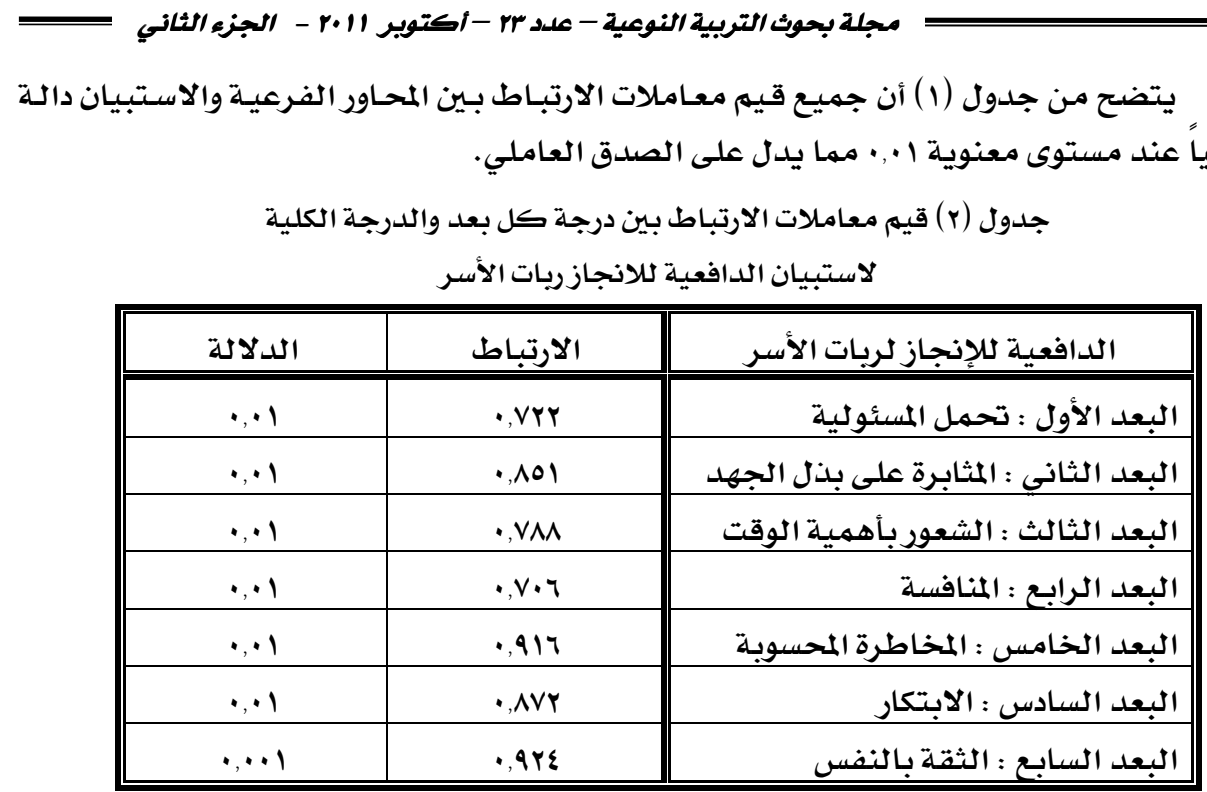

تبيـن مـن جـدول (r ) أن جميـع قيم معـاملات الارتبـاط بـين الأبعـاد الفرعيـة والاستبيان دالـة

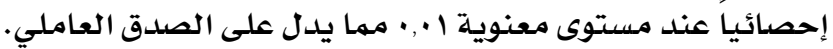
جدول (r) قيم معاملات الارتباط بين درجة كل محور والدرجة الكلية

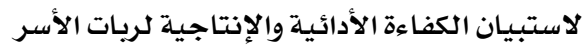

\begin{tabular}{|c|c|c|}
\hline 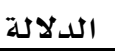 & الارتبـاط & الكفاءة الأدائية والإنتاجية لربات الأسر \\
\hline$\cdot, \cdot 1$ & •, Aro & المحور الأول : توافر القدرة على أداء العمل \\
\hline$\cdot, \cdot 1$ & $\cdot, \mathrm{vr} \varepsilon$ & المححور الثانى : توافر الرغبـة الحقيقية يِّ أداء العمل \\
\hline
\end{tabular}

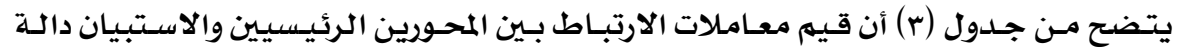

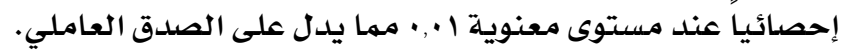

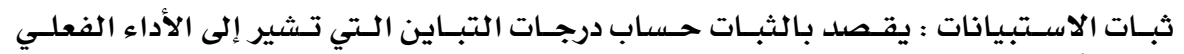

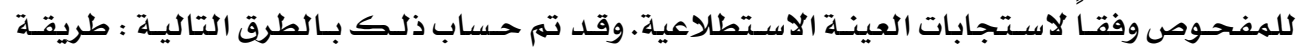

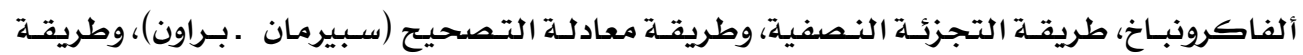

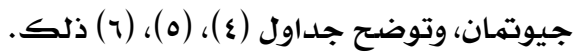


جدول (ع ) معامل الثبات لمحاور استبيان استخدام الأجهزة المنزلية الحديثة

\begin{tabular}{|c|c|c|c|c|}
\hline جيتهمان & سبيرمـان & التجزئة & معامل & المحاور \\
\hline$\cdot 9 r \cdot$ & .941 & $\cdot, \wedge \mathrm{V} \cdot$ & $\cdot 9 r 9$ & المحور الأول : طريقة الاستخدام المثلى \\
\hline$\cdot, \Lambda \cdot 0$ & •, Аro & $\cdot, \times 17$ & $\cdot, 119$ & المحور الثاني : طريقة العناية والتتظيف \\
\hline$\cdot, \mathrm{Y} \wedge$ & $\cdot, \mathrm{V} \vee \varepsilon$ & 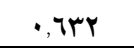 & $\cdot, V \varepsilon 0$ & المحور الثالث : طريقة التخزين السليهم والصيانة \\
\hline$\cdot, \wedge \varepsilon\rceil$ & $\cdot, \wedge \uparrow \wedge$ & $\cdot, \mathrm{V} \backslash \wedge$ & $\cdot, \wedge \circ 9$ & ثبـات الاستبيـان ككل \\
\hline
\end{tabular}

جدول (ه) معامل الثبات لأبعاد استبيان الدافعية لربات الأسر

\begin{tabular}{|c|c|c|c|c|}
\hline جيتمان & سبيريرمان & التجزئة النصفية & معامل ألفا & المحاور \\
\hline - Vrq & •,VA & . & , V07 & البعد الأول : تحمل المسئولية \\
\hline$\cdot, \wedge \vee \mathrm{T}$ & 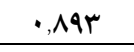 & $\cdot, \Lambda \cdot V$ & $\cdot, \wedge \wedge \vee$ & البعد الثاني : المثابرة على بذل الجهد \\
\hline$\cdot, V 71$ & $\cdot, \wedge \cdots$ & - TTV & $\cdot, \mathrm{VVV}$ & البعد الثالث : الشعور بأهميـة الوقت \\
\hline$\cdot, 9 \cdot r$ &., 917 & $\cdot, \wedge \leqslant 0$ & $.91 \%$ & البعد الرابع : المنافسـة \\
\hline •, Vo. & •, Var &., 700 & $\cdot, V T \vee$ & البعد الخامس : المخاطرة المحسوبـة \\
\hline., $91 Y$ & $.9 r \varepsilon$ & $\cdot, \wedge \bullet \wedge$ & $\cdot 9 Y 1$ & البعد السـادس : الابتكار \\
\hline$\cdot, \wedge \circ \vee$ & $\cdot, \wedge \mathrm{VV}$ & $\cdot, \mathrm{\wedge} \wedge \mathrm{I}$ & $\cdot, \wedge 79$ & البعد السـابع : الثقة بـالنفس \\
\hline •,AYT & -, ^or & $\cdot, V \leqslant Y$ & $\bullet, \wedge \varepsilon$ & ثبات الاستبيان ككل \\
\hline
\end{tabular}

جلدول (ج) معامل الثبات لمحاور استبيان الكفاءة الأدائية والإنتاجية لربات الأسر

\begin{tabular}{|c|c|c|c|c|}
\hline جيتهـان & سبيرمان & التجزئة النصفية & معامل ألفا & المحاور \\
\hline$\cdot, \wedge \wedge \uparrow$ & $\cdot, 9 \cdot 1$ & $\cdot, \wedge r \cdot$ & $\cdot, \wedge 97$ & المحور الأول : توافر القدرة على أداء العمل \\
\hline$\cdot, \vee \wedge \varepsilon$ & $\cdot, \Lambda \mid V$ & $\cdot, 791$ & $\cdot, \vee \vee 99$ & المحور الثاني : توافر الرغبـة الحقيقية ٍِِ أداء العمل \\
\hline$\cdot, \wedge \mu \mathrm{V}$ & $\cdot, \wedge \uparrow$. & $\cdot, \mathrm{V} 00$ & $\cdot, \wedge 0$. & ثبات الاستبيـان ككل \\
\hline
\end{tabular}

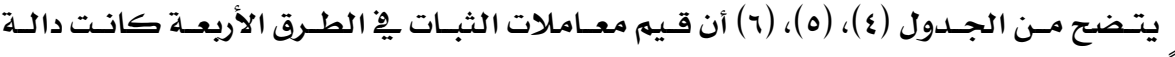

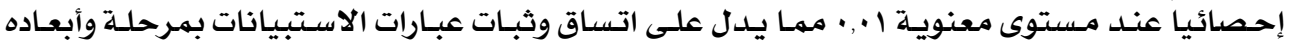
وبـذلك تكـون الاسـتبيانات صـالحـة للتطبيـق • وبنـاء على مـا سـبق أصسبحت الاسـتبـيانات فِ صـورتها 


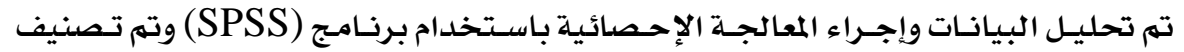

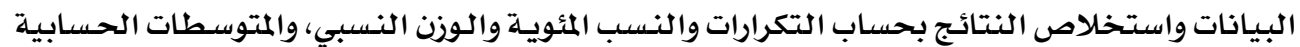

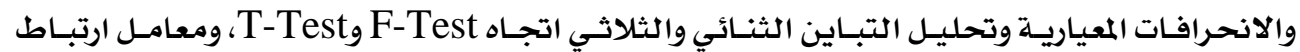

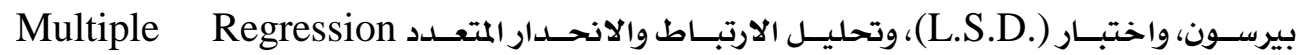

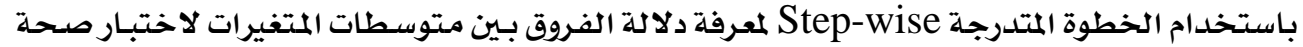
الفروض.

\section{نتائج الدراسة الميدانية وهناقشتهـا :}

أولاً : النتائج الوصفية : النورائ

فيما يلي عرض وصفي تحليلسي لتكرارات ونسب ومتوسـات استتجابات عينـة الدراسـة لبعض

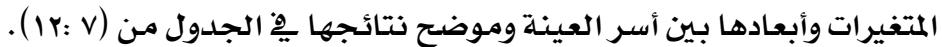

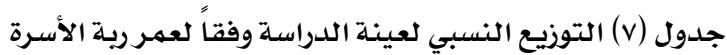

\begin{tabular}{|c|c|c|}
\hline النسبــة المئويـة ٪ & العلدد & العهمر \\
\hline$\% 1 \wedge$ & m & مـن هب سنـة إلى أقل مـن هب سنـة \\
\hline$\%$ \% , 0 & or & مـن هب سنـة إلى أقل مـن 0؛ سنــة \\
\hline & $7 V$ & مـن 0؛ سنـة إلى أقل مـن هـ سنـة \\
\hline$\%$ YY & $\varepsilon \varepsilon$ & من 00 سنـة فأكثر \\
\hline$\% 1 \ldots$ & r.. & المجموع \\
\hline
\end{tabular}

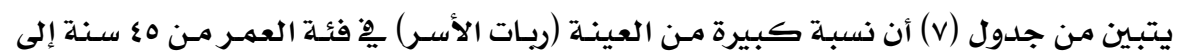

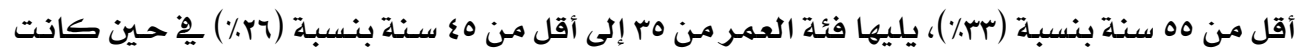

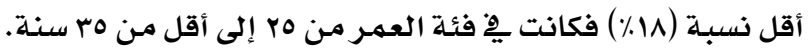
جدول (^) التوزيع النسبي لعينة البحث وفقاً لعهمل ربة الأسرة

\begin{tabular}{|c|c|c|}
\hline النسبـة المئويـة ٪ & العدد & العهل \\
\hline$\% .0 \mathrm{~V}$ & $11 \varepsilon$ & تعمل \\
\hline$\% \varepsilon r$ & $\Lambda T$ & لا تعمل \\
\hline$\% 1 \ldots$ & $r \cdots$ & المجموع \\
\hline
\end{tabular}

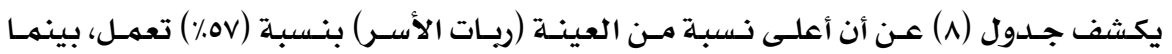

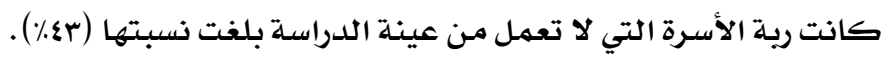


جدول (q) التوزيع النسبي لعينة الدراسة وفقا لمدة الزواج

\begin{tabular}{|c|c|c|}
\hline النسبــة المئويـة ٪ & 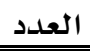 & مدة الزواج \\
\hline$\%$ & $\pi r$ & أقل من $\mid$ سنـة \\
\hline$\%$ \% , 0 & 19 & من $1 /$ سنـة إلى أقل مـ ·r سنـة \\
\hline$\%$ \%, 0 & $\sum 9$ & من · r سنـة فأكثر \\
\hline$\% 1 \ldots$ & r.. & المجموع \\
\hline
\end{tabular}

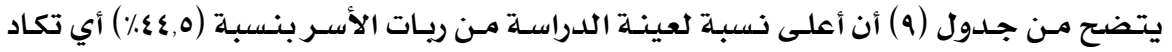

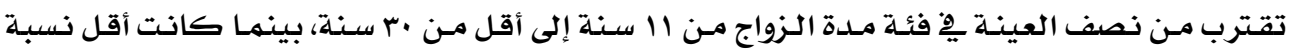

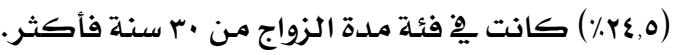
جدول ( ـ ) التوزيع النسبي لعينة الدراسة وفقاً لحجه الأسرة

\begin{tabular}{|c|c|c|}
\hline النسبـة المئويـة ٪ & 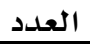 & حجم الأسرة \\
\hline$\%$ \% r, 0 & 70 & من r أفراد إلى ع أفراد (صغيرة الحجهم) \\
\hline$\% \varepsilon r, 0$ & $\Lambda \mathrm{V}$ & من ه أفراد إلى 7 أفراد (متوسطة الحجم) \\
\hline$\%$ \% & $\varepsilon \Lambda$ & V أفراد فأكثر (كبيرة الحجم) \\
\hline$\% 1 \ldots$ & r.. & ل المجموع \\
\hline
\end{tabular}

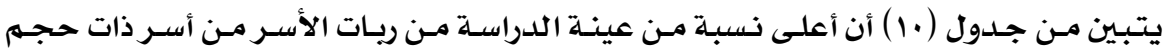

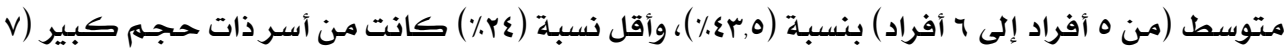

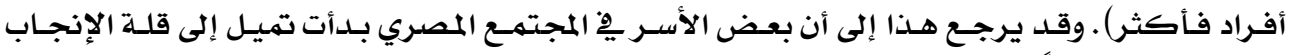

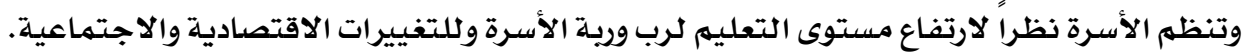
جدول (11) التوزيع النسبي لعينة الدراسة وفقاً لتعليم رية الأسرة

\begin{tabular}{|c|c|c|}
\hline النسبـة المئويـة ٪ & العدد ال العد & المستوى التعليمي \\
\hline$\% \varepsilon, 0$ & 9 & أمي "لا تقراً ولا تكتب" \\
\hline$\%$ & 17 & تقرأ وتكتب \\
\hline$\% 1 r, 0$ & ro & ابتدائيـة \\
\hline$\% 1 \mu, 0$ & $r V$ & إعداديـة \\
\hline$\% r \cdot, 0$ & \&1 & شهادة ثانوية وما يعاد لها \\
\hline$\%, \mu, 0$ & r & شهادة جـامعيـة \\
\hline$\%, 9,0$ & 19 & دراسـات عليا \\
\hline$\% 1 \ldots$ & r.. & المجموع \\
\hline
\end{tabular}




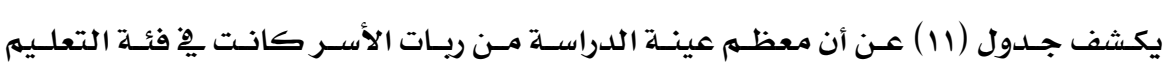

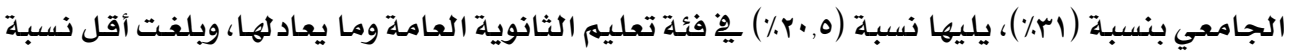

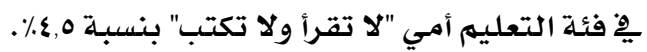
جدول (r) التوزيع النسبي لعينة الدراسة وفقاً للدخل الشهري الكلي للأسرة

\begin{tabular}{|c|c|c|}
\hline النسبسة المئويـة ٪ & العدد العد & العهمر \\
\hline$\%$ & ir & 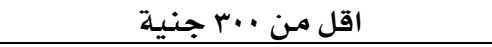 \\
\hline$\% 9$ & 11 & 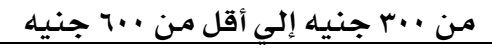 \\
\hline$\% 1 r$ & 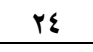 & من · · جنيه إلى أقل مـن · جـ جنيه \\
\hline$\% 11$ & rr & 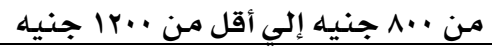 \\
\hline$\%$ YY,O & §० & 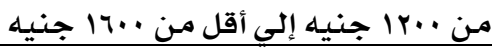 \\
\hline$\%$ YY & or & 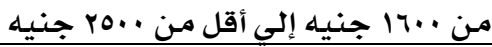 \\
\hline$\% 1 r, 0$ & YV & 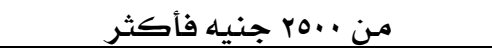 \\
\hline$\% 1 \ldots$ & $r \cdot$. & المجموع \\
\hline
\end{tabular}

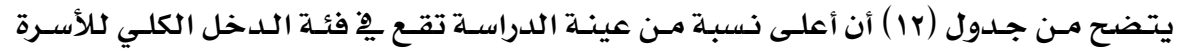

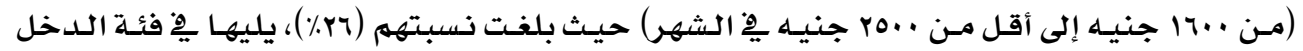

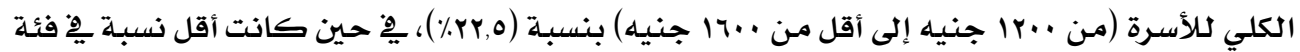

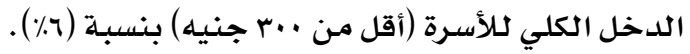

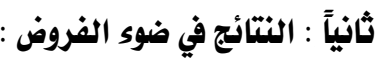
الفـرض الأول : "تختلف الأوزان النسبية لبعض الأجهزة المنزليـة الحديثـة موضـع الدراسـة تبعاً لأولولية استخدام ريات الأسر لها".

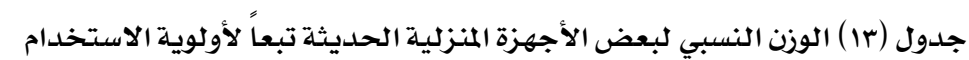

\begin{tabular}{|c|c|c|c|}
\hline الترتيب & النسبـة المئويـة ٪ & الوزن النسبي & الأجهزة المنزلية الحديثة \\
\hline الثاني & $\%$ \%r, r & rrr & المقلاة الكهريائية \\
\hline الأول & $\%$ \% & rV乏 & فرن الميكرويف \\
\hline \multirow[t]{2}{*}{ الثالث } & $\%$ \%৭,८ & rio & المفرمـة الكهريائية \\
\hline & $\% 1 \ldots$ & VYI & المجموع \\
\hline
\end{tabular}

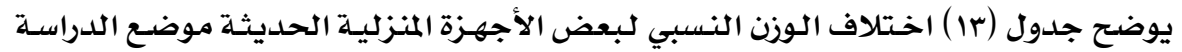

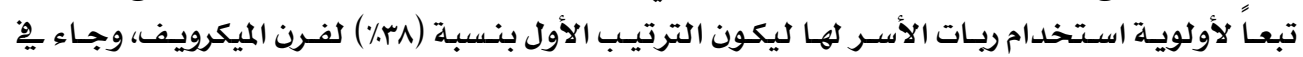

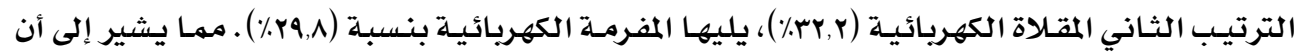

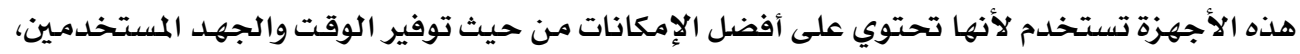


كذلك فإنه يحتوي على إمكانات أكثر تطورا أو وظائف محسنة سواء ِِّ عملية التحكم أو التشغيل

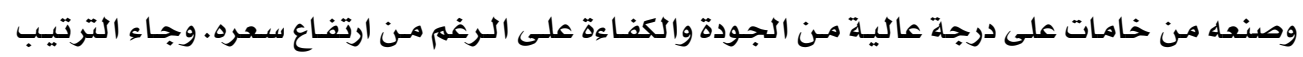

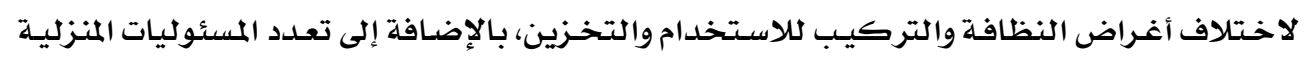

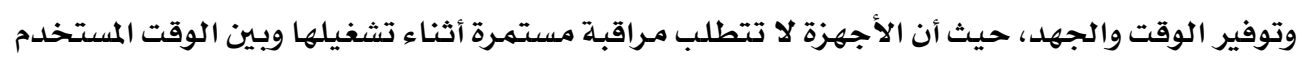

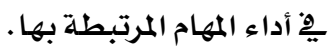

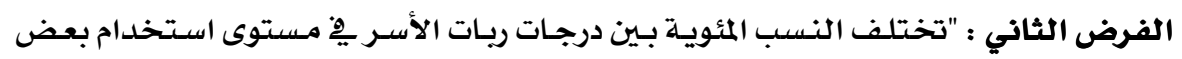

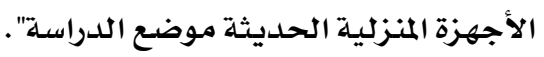

جدول (\& ا ) توزيع ريات الأسر تبعاً لمستوى استخدام بعض الأجهزة المنزلية الحديثة

\begin{tabular}{|c|c|c|c|c|c|c|c|c|}
\hline \multicolumn{2}{|c|}{ المجموع } & \multicolumn{2}{|c|}{ خاطئ أقل من } & \multicolumn{2}{|c|}{ متوسط أكثر } & \multicolumn{2}{|c|}{ صحيح } & \\
\hline | النسبـة/ & 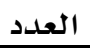 & | النسبة.| & العدد ال العد & |النسبة/| & العدد & |النسبةة|| & العدد & المنزلية الحلديثة \\
\hline$\% 1 \ldots$ & r.. & $\%$ \% & $\varepsilon \wedge$ & $\%$ \% & 117 & $\% 11$ & rq & طريقة الاستخدام \\
\hline$\% 1 \ldots$ & r.. & $\% \curlyvee \wedge, 0$ & ov & $\% \varepsilon \uparrow, 0$ & qr & $\%$ Yo & 0. & طريقة العناية والتنظيف \\
\hline$\% 1 \ldots$ & r.. & $\% ץ \varepsilon, 0$ & 79 & $\%$. & $1 \ldots$ & $\% 10,0$ & rl & طريقة التخزيـن والصيانة \\
\hline$\% 1 \ldots$ & r.. & $\%$ \% & 01 & $\% 01,0$ & $1 \cdot r$ & $\% 19,0$ & rq & الاستبيان ككل \\
\hline
\end{tabular}

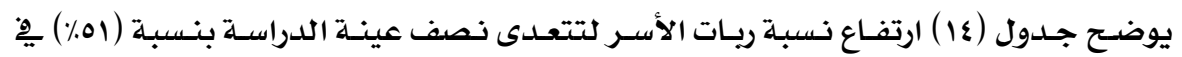

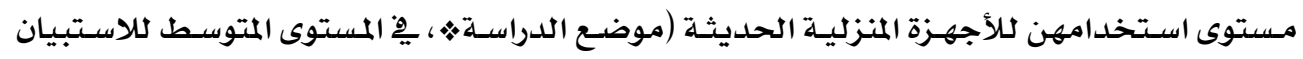

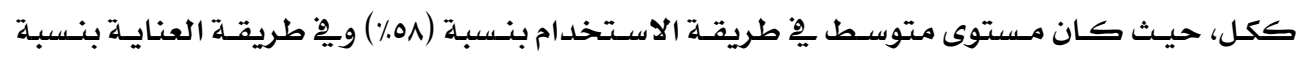

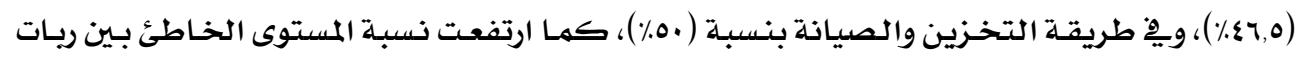

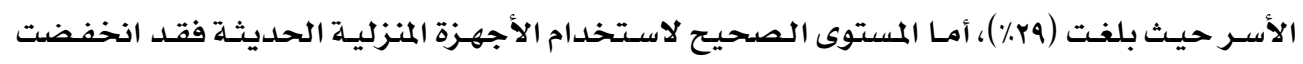

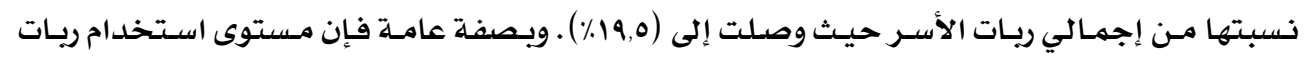

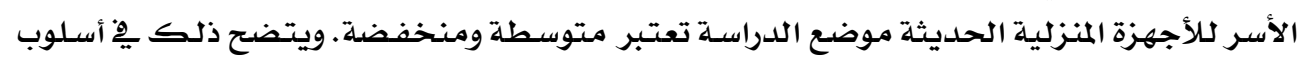
التشغيل والعناية والتنظيف والتخزين والصيانة التي تقوم بإتباعها عند الاستخدية التخدام.

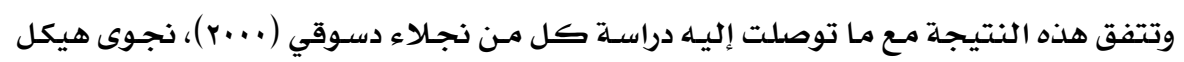

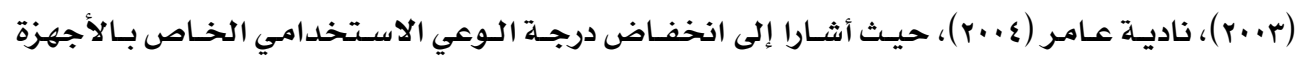

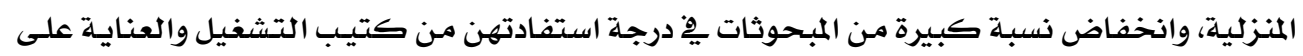

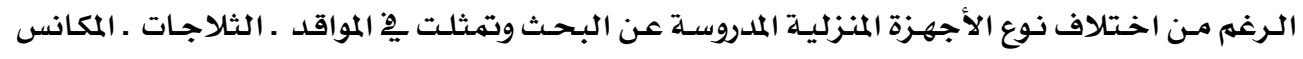


مجلة بحوث التربية النوعية - علد بr - أكتوبر ll م- - الجزء الثاني

وتتفق جزئياً مع دراسة شرين محفوظ (.... ( ) والذي أوضحت أن استخدام الكتيب الإرشادي

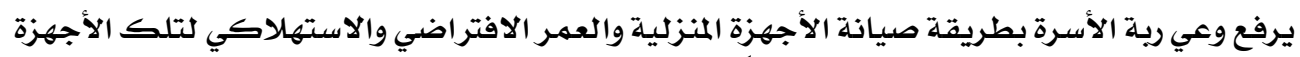

وبذلك يتحقق صحة الفرض الثاني جزئياً.

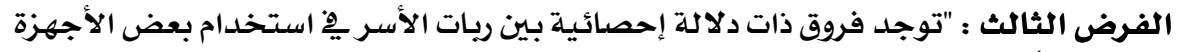

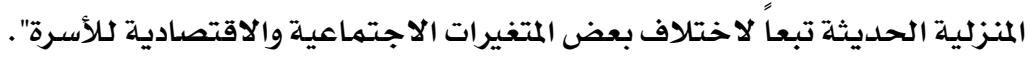

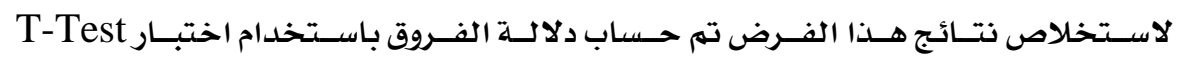

للمتغيرات ثنائية الأبعاد، واختبار F-Test لتحليل التباين للمتغيرات ثلاثية الأبعاد.

جدول (10) دلالدة الفروق بين متوسط درجات ريات الأسر بِ

استخدام بعض الأجهزة المنزلية الحديثة تبعاً لعمل رية الأسرة

\begin{tabular}{|c|c|c|c|c|c|c|}
\hline الدلاكة & قيمة & درجات & العينة & الانحراف & المتوسط الحسابي & العهل \\
\hline \multirow{2}{*}{ لصالح غير العاملات عند ا+.• } & \multirow{2}{*}{$r \cdot, V q V$} & \multirow{2}{*}{191} & $11 \varepsilon$ & rr, & I.V,rVV & تعهل \\
\hline & & & 17 & rr,qr. & $1 V 7,1990$ & لا تعمل \\
\hline
\end{tabular}

يتضح من جدول (10) وجود فروق ذات دلالة إحصائية عند مستوى دلالة ( ا., ) مِِّ استخدام

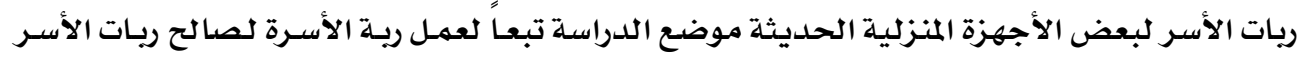

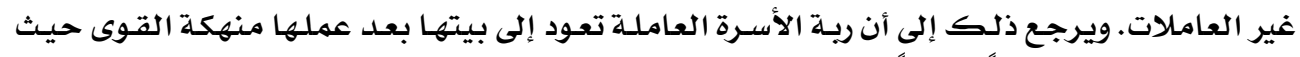

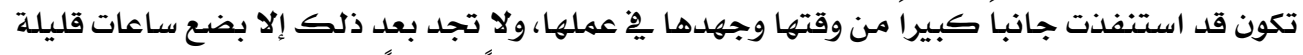

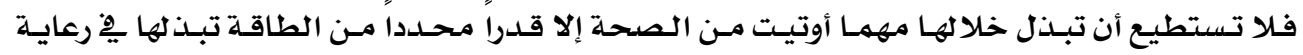

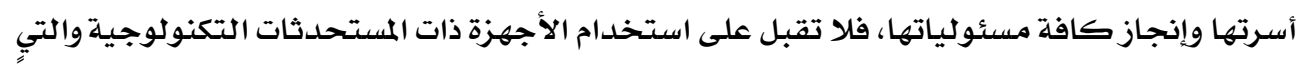

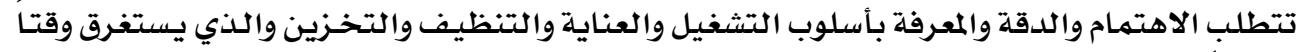

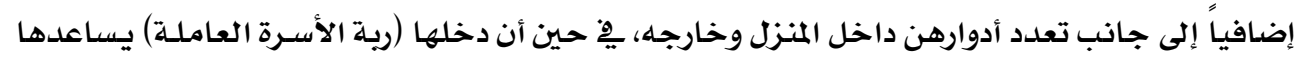

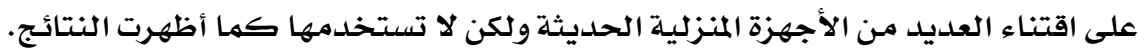


جدول (17) تحليل التباين بين ريات الأسر فِ استخدام ريات الأسر لبعض الأجهزة المنزلية الحديثة

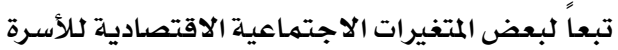

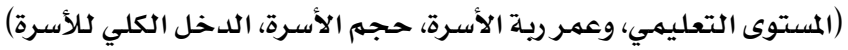

\begin{tabular}{|c|c|c|c|c|c|}
\hline الدلالة & قيمسة (ف) & درجات الحرية & متوسط المربعات & مجمبوع المربعات & المستوى التعليمي \\
\hline \multirow{3}{*}{ إ.,• دال } & \multirow{2}{*}{$\varepsilon \vee, r q ৭$} & $r$ & QMYYO,T. E & $M T T \leqslant 01, Y \cdot V$ & بين المجموعات \\
\hline & & $19 \mathrm{~V}$ & 1977,AYE & rAV$\leqslant T \leqslant, Y \varepsilon$. & داخل المجموعات \\
\hline & & 199 & & $O V P q \mid 0, \varepsilon \leqslant V$ & المجموع \\
\hline الدلالة & قيمـة (ف) & درجات الحرية & متوسط المربعات & مجمووع المربعات & العمر \\
\hline \multirow{3}{*}{ اי•,• دال } & \multirow{3}{*}{$\Lambda, \cdot 19$} & $r$ & Vะ094,770 & MrMVA.,99६ & بين المجموعات \\
\hline & & 197 & loor.sr. & $r \cdot\{\varepsilon V Y, r Y\}$ & داخل المجموعات \\
\hline & & 199 & & OYAYOY,rOD & المجموع \\
\hline الدلالة & قيمسة (ف) & درجات الحرية & متتوسط المربعات & مجمـوع المربعات & حجم الأسرة \\
\hline \multirow{3}{*}{ إ.,• دال } & \multirow{2}{*}{ ON,Y.r } & $r$ & AVY $\{\varepsilon, Y \vee O$ & $\mid V \leqslant \varepsilon \wedge \Lambda, 00$. & بين المجموعات \\
\hline & & $19 V$ & $1 \leqslant 91,99$. & r9or...90. & داخل المجمـوعات \\
\hline & & 199 & & $\varepsilon 79 \vee \wedge 9,0 \ldots$ & المجموع \\
\hline الدلالة & قيمة (ف) & درجات الحرية & متوسط المربعات & مجموع المربعات & الدخل الكلي للأسرة \\
\hline \multirow{3}{*}{ إ.,• دال } & \multirow{2}{*}{$0 \wedge,\{04$} & $r$ & $\Lambda Y \cdot Y 1,900$ & $17 \varepsilon \cdot \varepsilon r, 91$. & بين المجموعات \\
\hline & & $19 \mathrm{~V}$ & IE.r.,IrV & YVTE|A, $\cdot V \cdot$ & داخل المجموعات \\
\hline & & 199 & & $\varepsilon \varepsilon \cdot \varepsilon 71,9 \Lambda$. & المجموع \\
\hline
\end{tabular}

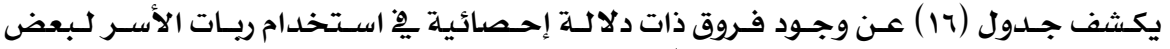

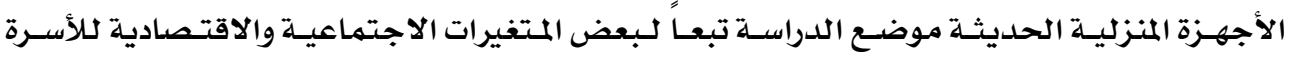

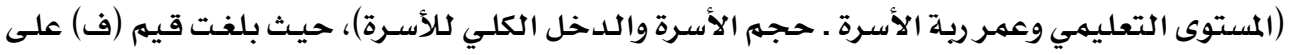

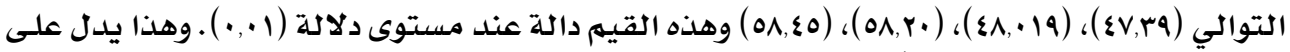

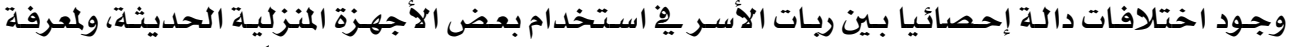

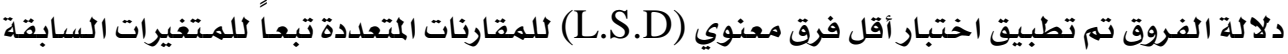

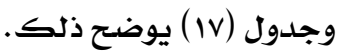




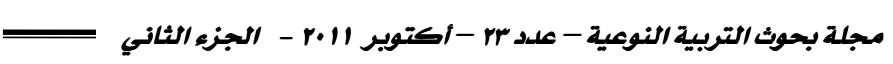

جدول (IV) دلالة الفروق بين ريـات الأسـرِِ استخدام ربات الأسر لبعض الأجهزة المنزلية الحديثة

تبعاً لبعض المتغيرات الاجتماعية والاقتصادية لكلأسرة

(المستوى التعليهـي، وعمـر ربـة الأسرة، حجم الأسـرة، الدخل الكلي لكلأسـرة)

\begin{tabular}{|c|c|c|c|}
\hline 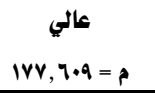 & 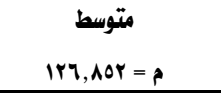 & 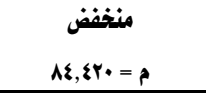 & المستوى التعليمي \\
\hline & & - & منخفض (أمي ـ تقرأ وتكتب ابتدائي) \\
\hline & - & $* * \varepsilon r, \varepsilon r r$ & متوسط (تعليم متوسط ـ فوق متوسط) \\
\hline- & $* * 0,, \mathrm{~V} \bullet \mathrm{T}$ & $* * q 4,1 \wedge q$ & عالي (جامعي ـ دراسات عليا) \\
\hline من ه سنة إلى & من ro سنة إلى & 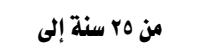 & \\
\hline أقل من ه سنة & أقل من 0؟ سنة & أقل من ro سنة & العمر \\
\hline \multirow[t]{3}{*}{$|\xi|, r T \Lambda=P$} & $19 \cdot, Y 9 Y=R$ & $\|r, 7\|=\beta$ & \\
\hline & & - & من ro سنة إلى أقل من ro سنة \\
\hline & - & $* * \vee \vee,|\wedge|$ & من ro سنة إلى أقل من مـ سنة \\
\hline- & $* * \varepsilon q, \Delta \Delta r$ & $* * r v, \tau r v$ & من هء سنة إلى أقل من ه0 سنة \\
\hline$* * 07,1, r$ & $* * 1,0,707$ & $* * \curlyvee \wedge, \varepsilon \vee \leqslant$ & من مه سنة فأكثر \\
\hline \multirow[t]{3}{*}{ 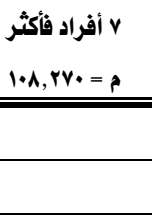 } & 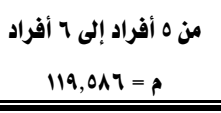 & 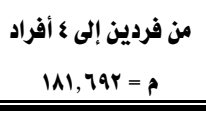 & 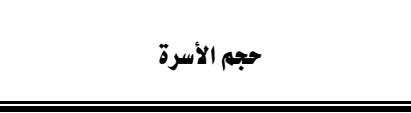 \\
\hline & & - & من فردين إلى ع أفراد (صفيرة الحجم) \\
\hline & - & $* * q r, 1, q$ & من ه أفراد إلى 7 أفراد (متوسطة الحجم) \\
\hline- & $* 11, \pi 10$ & $* * V Y, \leqslant r 1$ & v أفراد فأكثر (كبيرة الحجه) \\
\hline \multirow[t]{3}{*}{ 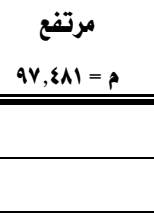 } & 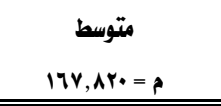 & $\begin{array}{c}\text { منغفض } \\
\text { 107, rvV = P } \\
\end{array}$ & 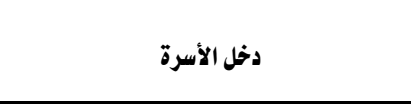 \\
\hline & & - & منخفض (من •+r جنيه إلى أقل من .•^ جنيه) \\
\hline & - & $* 11, \cdot \leq r$ & متوسط (من •^ جنيه إلى أقل من ..17 جنيه) \\
\hline- & $* * v \cdot, r r q$ & $* * \diamond ৭$, ४ १ & مرتفع (من ..17 جنيه فأكثر) \\
\hline
\end{tabular}

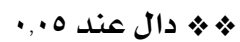

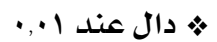

يتـبـين مـن جـدول (IV) وجـود فـروق ذات دلالــة إحــصائية ِِِ اسـتخدام ريـات الأسـر لـبعض

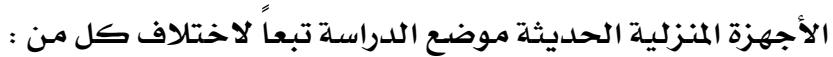

• بالنسبة للمستوى التعليمي لرية الأسرة : حيث كانت هنـاك فروق معنويـة دالـة عند مستوى دلالة (ه •. • ) لصالح مستوى التعليهم العالي (الجامعي) . مها يوضـح أن ريـات الأسـر ذات التعليهم العالي أكثر استخدامـا للأجهزة المنزليـة الحديثثة موضـع الدراسـة مـن ريـات الأسـر ذات التعلـيهم المتوسط والمنخفض، ويرجـ ذلك إلى أنه كلهـا ارتفـع مستوى تعليهم المرأة كلهـا اتسع أفقها 


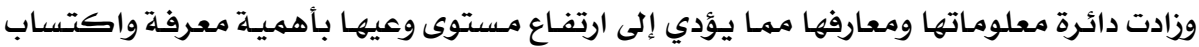

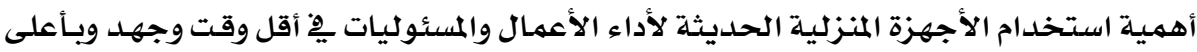
كفاءة وجودة.

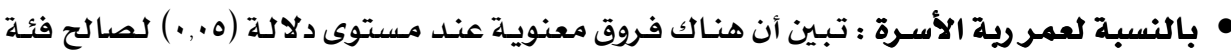

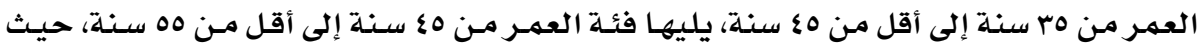

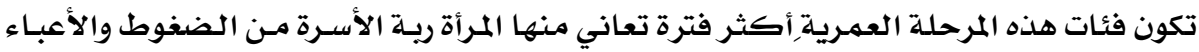
والمسئوليات المنزلية والمهنية.

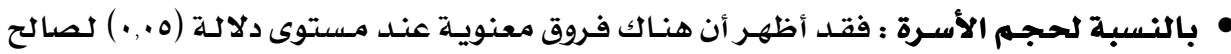

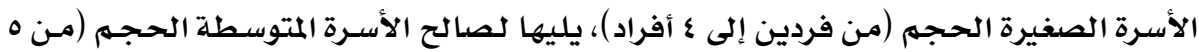

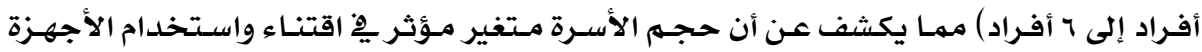

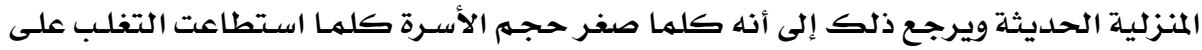

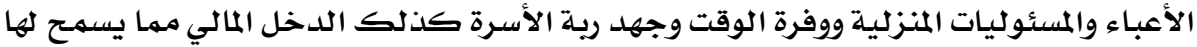

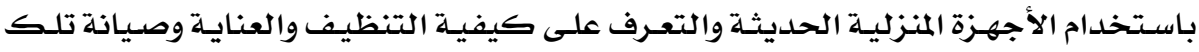

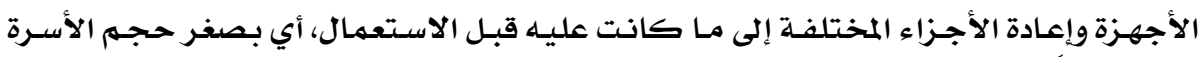

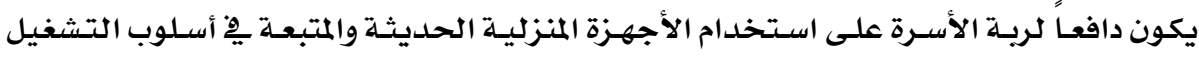

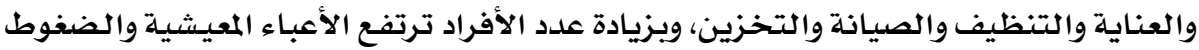

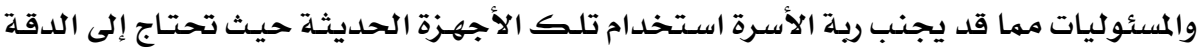

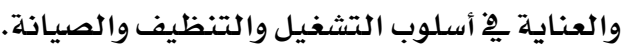

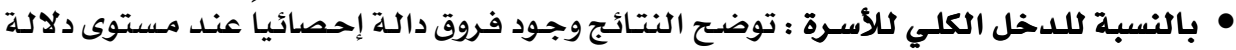

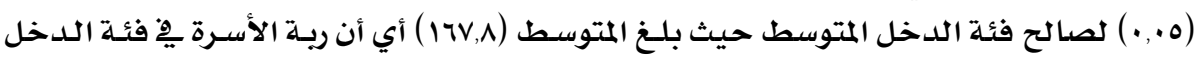

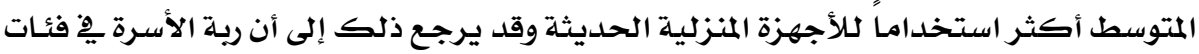

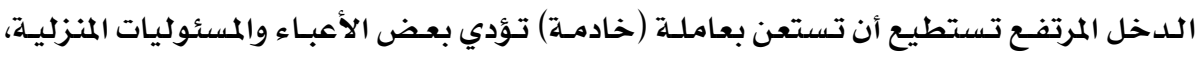

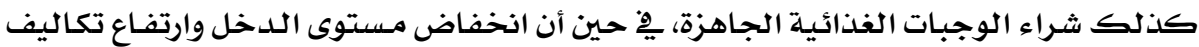

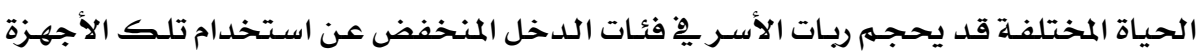

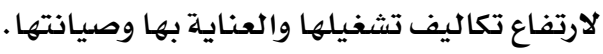

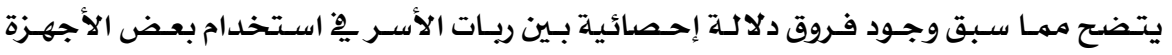

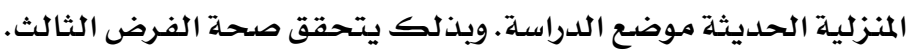

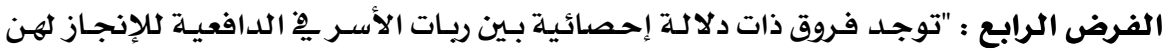
تبعاً لاختلاف بعض المتغيرات الاجتماعية والاقتصادية لكلأسرة" .

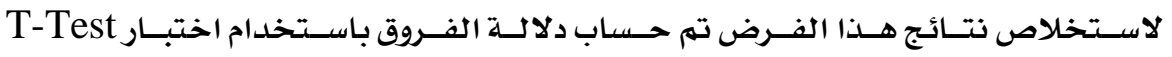
للمتغيرات ثنائية الأبعاد، واختبار F-Test لتحليل التباين للمتغيرات ثلاثية الأبعاد. 
مجلة بحوث التربية النوعية - علد سr - أكتوبر ll - - الجزء الثانسي

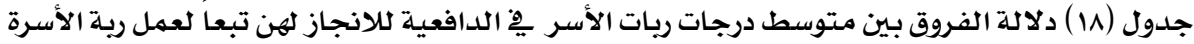

\begin{tabular}{|c|c|c|c|c|c|c|}
\hline الدلالة & قيمـة & درجات & العينة & الانحراف & المتوسط الحسابي & العمل \\
\hline \multirow{2}{*}{ لصالح العـامـلات ال•• } & \multirow{2}{*}{19,011} & \multirow{2}{*}{191} & $11 \varepsilon$ & $\mid\{, \wedge 9 \mid$ & $90, \vee \wedge$. & تعمل \\
\hline & & & $\Lambda T$ & 11,291 & $\Delta V, T \cdot \varepsilon$ & لا تعمل \\
\hline
\end{tabular}

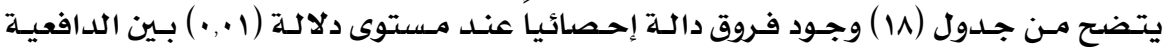

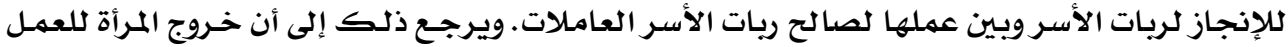

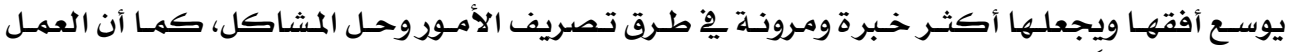

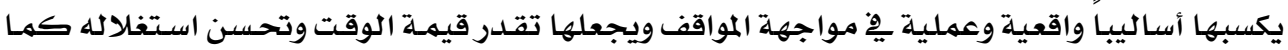
تقلدر قيمـة المـوارد التكنولوجيـة الحلديثـة المتوافرة لـلأسـرة والتي تعينهها على أداء مسسئولياتها وأعبائها المنزليـة وأن الأجهزة الحديثـة أصسبحت شـيئا ضـروريا وليسـت كماليـا، لأنها تـوفر الوقت والجهـد مهـا

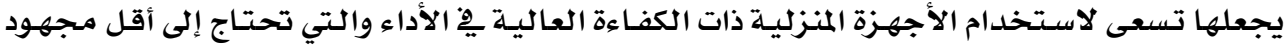

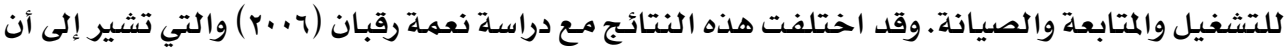
المرأة العاملة أقل دافعيـة للإنجاز مـن غير العاملة نتيجـة لتعدد أدوارهن داخل المنزل وخـارجه. جلدول (19) تحليل التباين بين ريات الأسر ِِّ الدافعية للإنجاز لهن تبعاً لبعض المتغيرات الاجتماعية

والاقتصادية للأسـرة (المستوى التعليهي، وعمر ربـة الأسـرة، حجم الأسـرة، الدخل الكلي للأسرة)

\begin{tabular}{|c|c|c|c|c|c|}
\hline الدلالة & قيمة (ف) & درجات الحرية & متوسط المربعات & مجموع المربعات & المستوى التعليمي \\
\hline \multirow{2}{*}{ ו•,• داJ } & \multirow{2}{*}{ \&A, IT. } & $r$ & rerar, IV. & 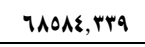 & بين المجموعات \\
\hline & & 194 & MIY,EAT & $18 \cdot r 0 q, r 17$ & داخل المجموعات \\
\hline & & 199 & & $r+\wedge 9 \leqslant r, 000$ & المجموع \\
\hline الدلالة & قيمة (ف) & درجات الحرية & متوسط المربعات & مجموع المربعات & العمر \\
\hline \multirow{3}{*}{ ا•,••دال } & \multirow{2}{*}{$0 \cdot, 0 \cdot v$} & $r$ & rIr.V,OAN & IrqTr, var & بين المجموعات \\
\hline & & 197 & $\{19, \wedge 91$ & ArrqA,OAr & داخل المججموعات \\
\hline & & 199 & & IEOAYI, roO & المجموع \\
\hline الدلالة & قيمة (ف) & درجات العرية & متوسط المربعات & مجموع المربعات & حجم الأسرة \\
\hline \multirow{2}{*}{ ا•,••دال } & \multirow{2}{*}{$r v, \wedge 70$} & r & KIIY\&,99६ & 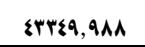 & بين المجموعات \\
\hline & & $19 \mathrm{~V}$ & orr,zra & \|rvYA, 7\|" & داخل المججوعات \\
\hline & & 199 & & 107111,099 & المجموع \\
\hline الدلالة & قيمة (ف) & درجات الحرية & متوسط المربعات & مجموع المربعات & الدخل الكلي للأسرة \\
\hline \multirow{3}{*}{ اי,••دال } & \multirow{2}{*}{$\cdot, \wedge r \wedge$} & r & $r \cdot r \wedge \cdot, r \xi \cdot$ & $\$ 107 \cdot, \$ \Lambda^{\circ}$ & بين المجموعات \\
\hline & & $19 \gamma$ & $0.1,9 \times 0$ & l..rqA,... & داخل المجموعات \\
\hline & & 199 & & IEIAYA,\&A. & المجموع \\
\hline
\end{tabular}


يتبين من جدول (19) ) عن وجود فروق ذات دلالـة إحصائية يِ الدافعيـة للإنجـاز لريـات الأسـر

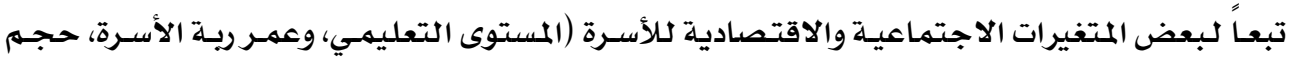

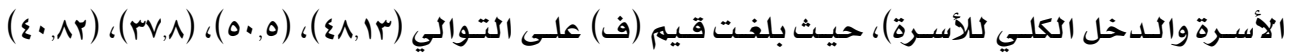

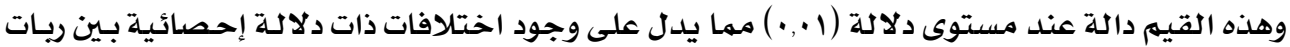

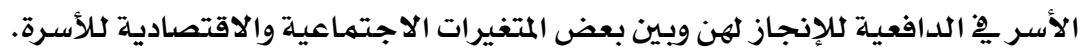

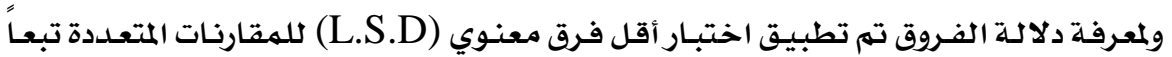

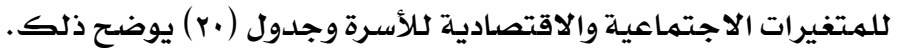

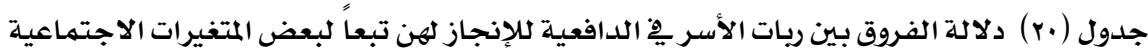

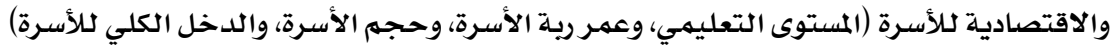

\begin{tabular}{|c|c|c|c|}
\hline م = عالي & $\begin{array}{c}\text { متوسط } \\
\text { V乏, V9 = P }\end{array}$ & 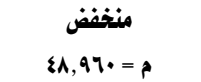 & المستوى التعليمي \\
\hline & & ------- & منذفض (أمي ـ تقرأ وتكتب ابتدائي) \\
\hline & ------- & $* * Y \diamond, \wedge r \varepsilon$ & متوسط (تعليم متوسط ـ فوق متوسط) \\
\hline ------- & $* *$ * $, 9,1$ & $* * \Delta Y, \vee \sim \Delta$ & عالي (جامعي ـ دراسات عليا) \\
\hline من 0؟ سنة إلى & من مب سنة إلى & من مب سنة إلى & \\
\hline أقل من ه سنة & أقل من هـ سنة & أقل من ro سنة & 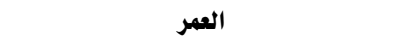 \\
\hline \multirow[t]{3}{*}{$9 r, r O A=p$} & $9 Y, \Delta \wedge \varepsilon=\hat{R}$ & $7 r, q \leq \varepsilon=p$ & \\
\hline & & ------- & من ro سنة إلى أقل من ب سنة \\
\hline & ------- & $* * r, \tau \leq$. & من ro سنة إلى أقل من 0؟ سنة \\
\hline ------- & *0, r צ & $* * \uparrow \wedge, \varepsilon \mid r$ & من 0ء سنة إلى أقل من ه هنة \\
\hline$* * \varepsilon r, 1 \cdot \Lambda$ & $* * \varepsilon V, r r \varepsilon$ & $* * 17,79 \leq$ & من مه سنة فأكثر \\
\hline \multirow[t]{3}{*}{ 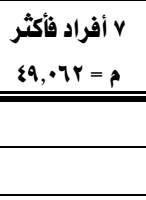 } & 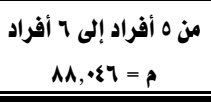 & 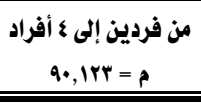 & 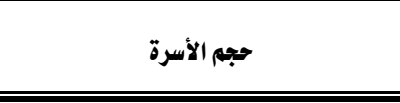 \\
\hline & & ------- & من فردين إلى ع أفراد (صفيرة الحجم) \\
\hline & ------- & $r, \cdot v V$ & من ه أفراد إلى 7 أفراد (متوسطة الحجم) \\
\hline ------- & $* * r \wedge, ৭ \wedge r$ & $* * \leqslant 1, .7$ & V أفراد فأكثر (كبيرة الحجم) v \\
\hline \multirow[t]{3}{*}{$\begin{array}{c}\text { مرتفع } \\
\wedge 0,9 \wedge v=\text { م }\end{array}$} & متوسط & منغفض & 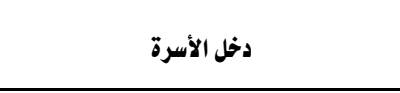 \\
\hline & & ------- & منخفض (من •.ب جنيه إلى أقل من ..1 جنيه) \\
\hline & ------- & $* * r \wedge$, or & متوسط (من ..1 جنيه إلى أقل من ..19 جنيه) \\
\hline ------- & $* q, Y 01$ & $* * r r, r \wedge r$ & مرتفع (من ..717 جنيه فأكثر) \\
\hline
\end{tabular}

• \&. دال عند مستوى دلادلة (ه.,.). • • دال عند مستوى دلادلة (1.,.).

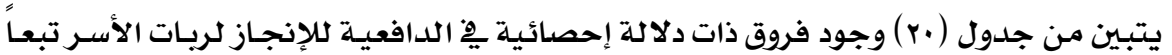

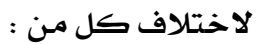




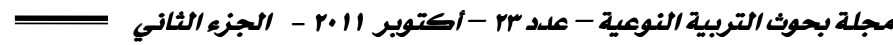

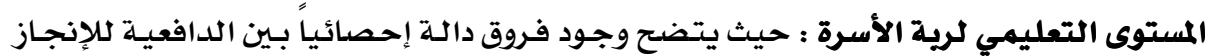

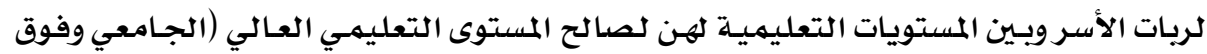

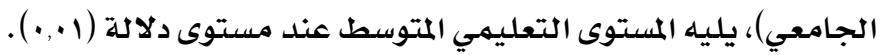

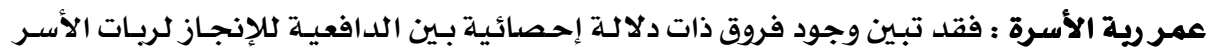

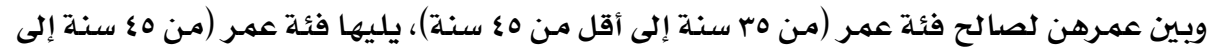

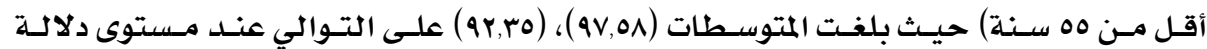
.$(\cdot, \cdot 0)$

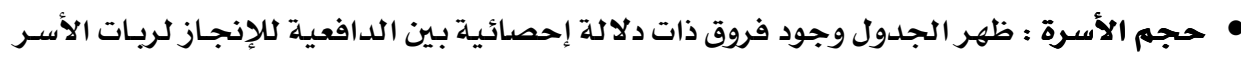

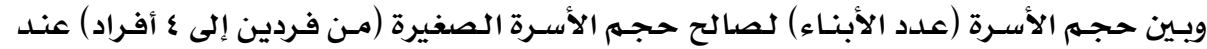

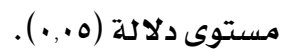

• الدخل الكلي للأسرة : أوضحت عن وجود فروق ذاهدات دلالة إحصائية بين الدافعية للإنجاز لربات

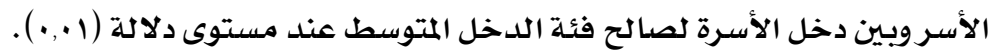

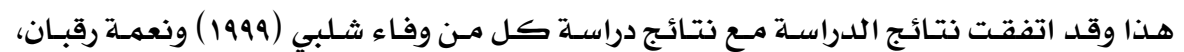

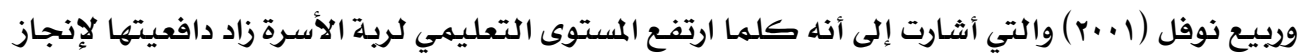

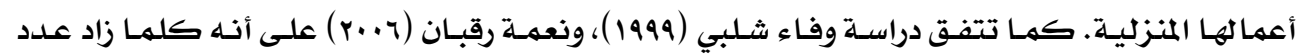

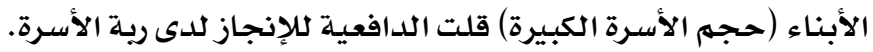

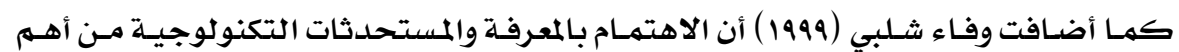
سمات المرأة التي تتمتعع بدافعية عالية لإنجاز

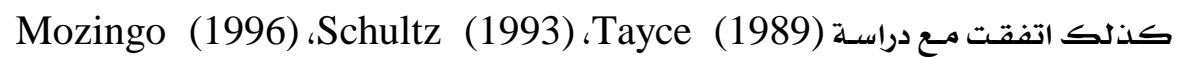
والتي أوضحت أن المستوى الاجتماعي الاقتصادي له تأثير دال موجب ِِّ الدافعية للإنجاز.

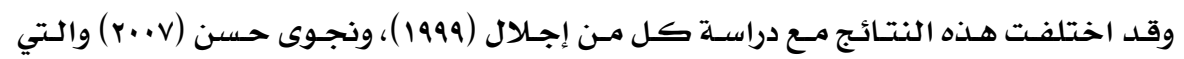

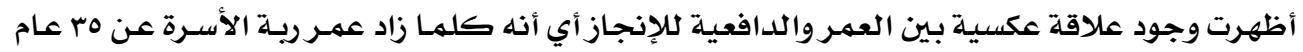
كلما قلت دافعيتهم للإنجاز.

يتضح مما سبق من نتائج وجود فروق ذات دلالة إحصائية بين ريات الأسـر ِِّ دافعيـة للإنجـاز

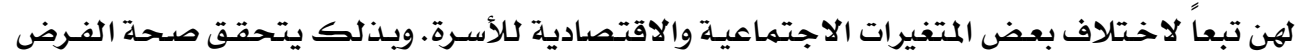
الرابع.

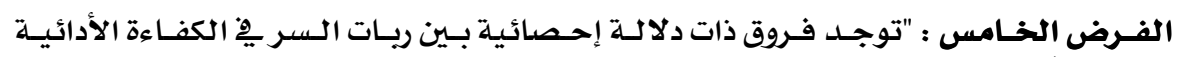

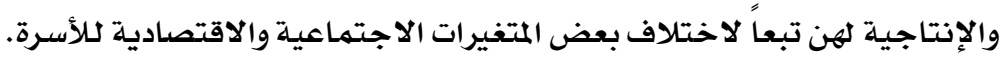

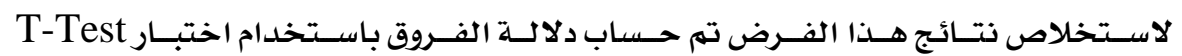
للمتغيرات ثنائية الأبعاد، واختبار F-Test لتحليل التباين للمتغيرات ثلاثية الأبعاد. 
جدول (Y) د دالدة الفروق بين متوسط درجات ريات الأسر

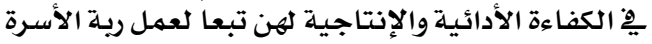

\begin{tabular}{|c|c|c|c|c|c|c|}
\hline الدلالة & قيمة (ت) & درجات الحرية & العينة & الانحراف المعياري & المتوسط الحسابي & العمل \\
\hline \multirow{2}{*}{ لصال عند ال, } & \multirow{2}{*}{$r 1,790$} & \multirow{2}{*}{191} & $11 \varepsilon$ & $10, r \leqslant A$ & Vr, $\{r q$ & تعمل \\
\hline & & & $\Lambda 9$ & A,OY\& & $\{r, \Lambda \leqslant \wedge$ & لا تعمل \\
\hline
\end{tabular}

يتضح من جدول (Y) وجود فروق ذات دلالة إحصائية بين الكفاءة الأدائية والإنتاجية لريسات

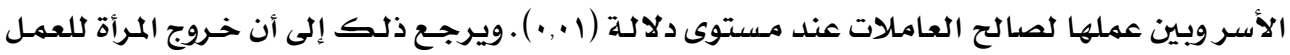

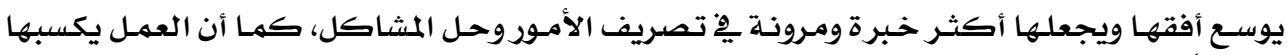

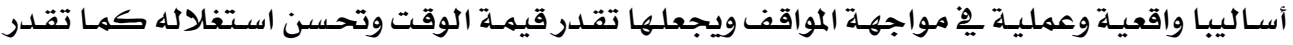

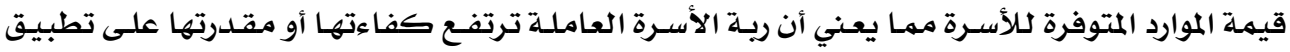

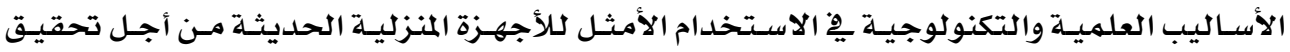
أهدافها وأهداف الأسرة المنشودة.

هذا وقد اتفقت نتائج الدراسـة مع نتائج دراسـة جيلان قباني ووفاء شلبي (199r) والتي أشارت

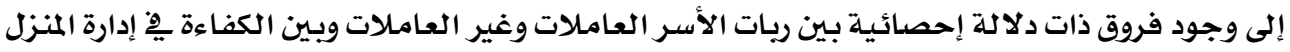
لصالح رية الأسرة العاملـة. جدول (rr) تحليل التباين بين ريات الأسر بِّ الكفاءة الأدائية والإنتاجية للإنجاز لهن تبعاً لبعض المتغيرات

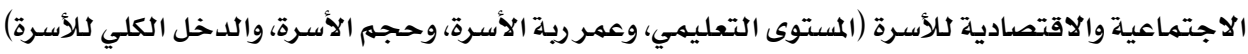

\begin{tabular}{|c|c|c|c|c|c|}
\hline الدلالة & قيمة (ف) & درجات الحرية & متوسط المربعات & مجموع المربعات & المستوى التعليمي \\
\hline \multirow{3}{*}{ 1 ••, داJ } & \multirow{2}{*}{$9, \wedge 09$} & $r$ & $19 V r A, \cdot 1 \varepsilon$ & rq々VY, PV & بين المجموعات \\
\hline & & $19 r$ & $r 90, \wedge r v$ & rVaAv, r\&Y & داخل المججموعات \\
\hline & & 199 & & 11หร7r, หา9 & المجموع \\
\hline الدلالة & قيمة (ف) & درجات الحرية & متوسط المربعات & مجموع المربعات & العمر \\
\hline \multirow{3}{*}{ اי,•• دال } & \multirow{2}{*}{$\$ 1,1 \wedge 9$} & $r$ & IEIVO, •rY & Eroro, $\bullet$ Ar & بين المجموعات \\
\hline & & 197 & $r \leqslant \varepsilon, 1 \leqslant r$ & TV\&OI,AVr & داخل المججموعات \\
\hline & & 199 & & $1.99 \times 7,900$ & المجموع \\
\hline الدلالة & قيمة (ف) & درجات الحرية & متوسط المربعات & مجموع المربعات & حجم الأسرة \\
\hline \multirow{3}{*}{ ا•,•• دال } & \multirow{2}{*}{$Y, \wedge \mid \wedge$} & $r$ & |AETI, rIE & rฯATr,\&YY & بين المجموعات \\
\hline & & $19 r$ & $r \wedge 0, \Sigma \llbracket \varepsilon$ & YoATr, ¿OY & داخل المججموعات \\
\hline & & 199 & & IIrYA\&, АA. & المجهوع \\
\hline الدلالة & قيمة (ف) & درجات الحرية & متوسط المربعات & مجموع المربعات & الدخل الكلي للأسرة \\
\hline \multirow{3}{*}{ וי,• داJ } & \multirow{3}{*}{$v, 090$} & r & 199rq,.1. & 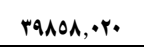 & بين المجموعات \\
\hline & & lar & sı, VY. & AYEAY,qYq & داخل المجموعات \\
\hline & & 199 & & Irrrso, 9ะ9 & المجموع \\
\hline
\end{tabular}




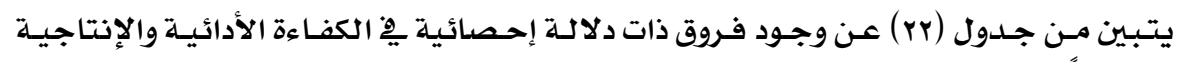

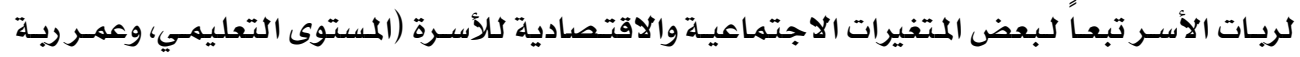

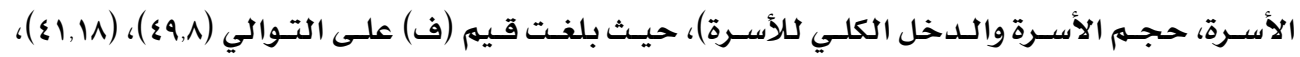

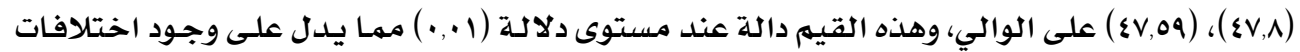

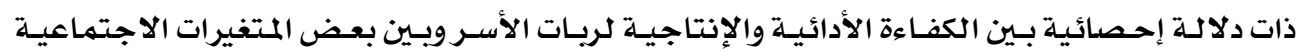
والاقتصادية لكلأسرة.

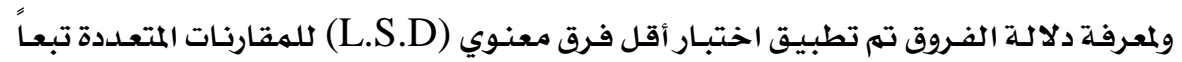

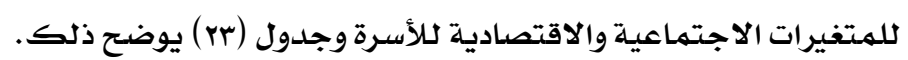

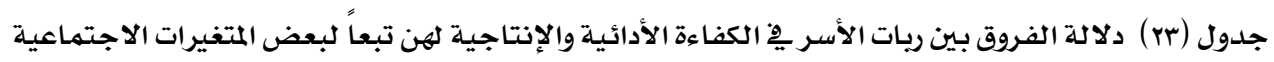

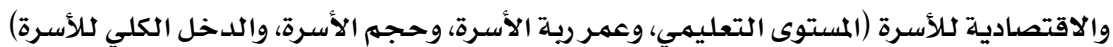

\begin{tabular}{|c|c|c|c|}
\hline $\begin{array}{c}\text { ets } \\
\text { vv, } 790=\text { P }\end{array}$ & 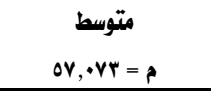 & منخفض & المستوى التمليمي \\
\hline & & ------ & منخفض (أمي ـ تقرأ وتكتب ابتدائي) \\
\hline & ------ & $* * 19, r \vee r$ & متوسط (تعليي متوسط ـ فوق متوسط) \\
\hline ------- & $* * r \cdot, Y r)$ & $* * \% q, \wedge 90$ & عالي (جامعي ـ دراسات عليا) \\
\hline من 0ح سنة إلى & من هr سنة إلى & من 0r سنة إلى & \\
\hline أقل من هه سنة & أقل من 0؛ سنة & أقل من مr سنة & العمر \\
\hline \multirow[t]{3}{*}{$\Lambda \cdot, r r r=P$} & $7 r, \cdot 1 \Lambda=P$ & $01,0 \cdots+\cdots$ & \\
\hline & & ----- & مز هr سنة إلى أقل من هr سنة \\
\hline & ------ & $* * 1 \cdot, 01 \wedge$ & من 0ب سنة إلى أقل من 0؛ سنة \\
\hline ------ & $* * \mid \wedge, \uparrow, 0$ & $* * \curlyvee \wedge, \vee r r$ & مز 0ء سنة إلى أقل من هه سنة \\
\hline$* * \varepsilon r, \nvdash ч q$ & $* * r \bullet,+7 \varepsilon$ & $* * 1 \leq, 0 \leq 0$ & من مه سنة فأكثر \\
\hline \multirow[t]{3}{*}{ 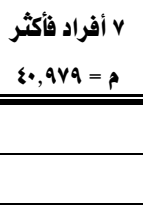 } & 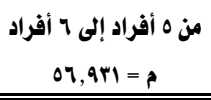 & 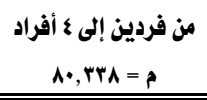 & 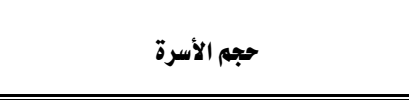 \\
\hline & & & من فردين إلى ع أفراد (صغيرة الحجم) \\
\hline & ------ & $* * r r, \varepsilon \cdot V$ & من ه أفراد إذى 7 أفراد (متوسطة الحجم) \\
\hline ------- & $* * 10,901$ & $* * \sim q, \sim \circ q$ & v أفراد فأكثر (كبيرة الحجم) \\
\hline \multirow[t]{4}{*}{ مرتفع = = } & 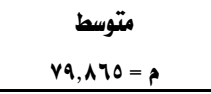 & 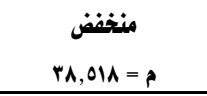 & 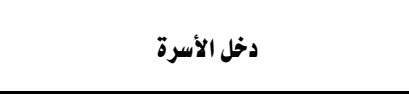 \\
\hline & & ----- & منخفض (من •+r جنيه إلى أقل من •+1 جنيه) \\
\hline & ------ & $* * \varepsilon 1, \Psi \leq V$ & متوسط (هن •+1 جنيه إلى أقل من •.17 جنيه) \\
\hline & $* * r \cdot, r r r$ & $* * Y 1,11 \varepsilon$ & مرتفع (من +.7 اجنيه فأكثر) \\
\hline
\end{tabular}

•. • دال عند مستوى دلالة (ه.,•). • مال عند مستوى دلالة (1.,.). 


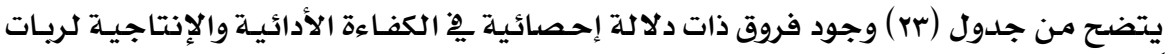
الأسر تبعاً لاختلاف كل من :

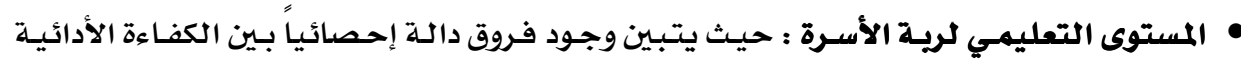

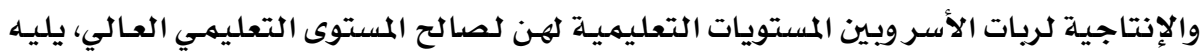
المستوى التعليمي المتوسط عند مستوى دلالنة (1...•).

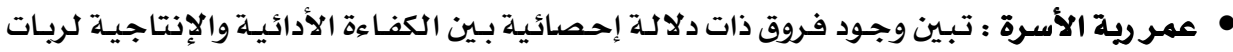

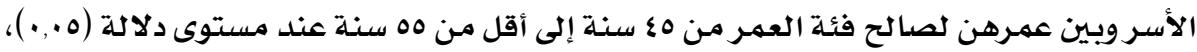

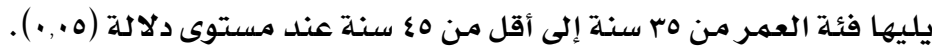

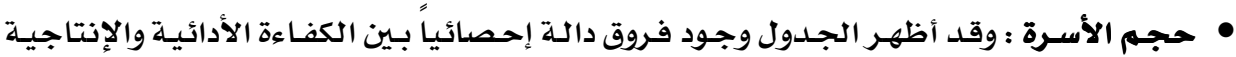

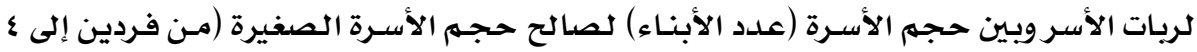
أفراد) عند مستوى دلالة (0., •).

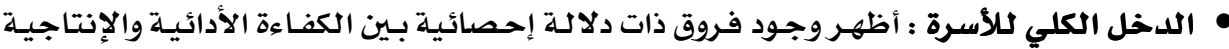

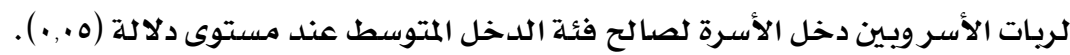

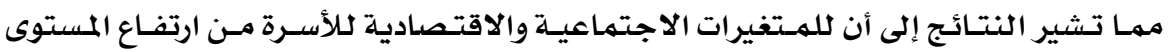

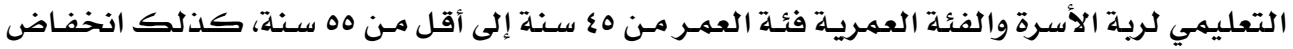

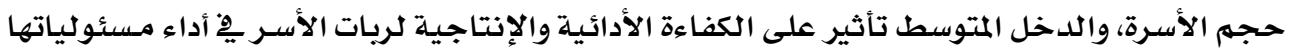

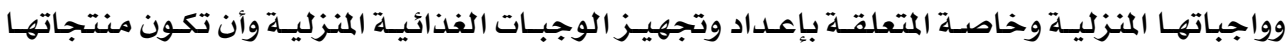

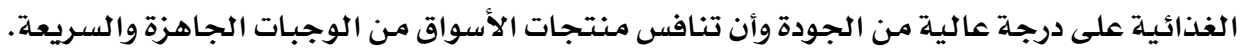

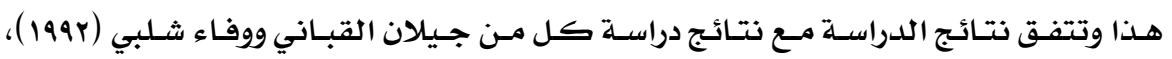

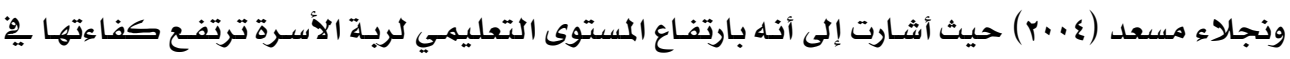

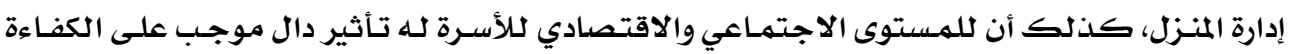
لربية الأسرة. مما سبق من تفسير النتائج تبين وجود فروق ذات دلالة إحصائية بـين ريـات إلأسـر بِ الكفـاءة

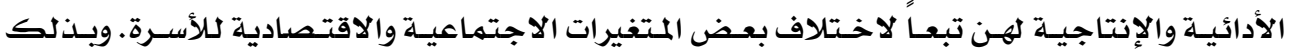
يتحقق صحة الفرض الخامس. الفرض السـادس : "توجـد علاقـة ارتباطيـة بـين الدافعيـة للإنجـاز بأبعادها والكفـاءة الأدائيـة

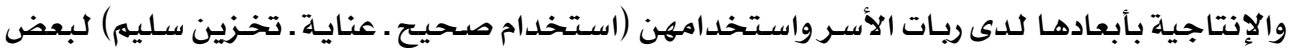

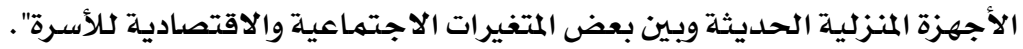
وللتحقق مـن صـحة الفـرض تم إجـراء معـاملات الارتبـاط باستخدام عامـل ارتبـاط بيرسـون

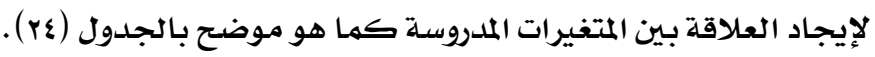


مجلة بحوث التربية النوعية - علد سr - أكتوبر ll م - الجزء الثاني ب

$$
\text { جدول (rع) بالعرض }
$$


الفرض السابع : "توجد علاقة ارتباطية بين استخدام ريات الأسـر (استخدام صسحيح ـ عنايـة

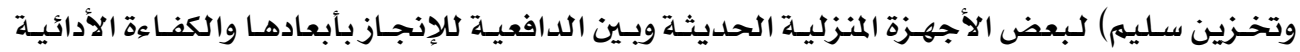
والإنتاجية بأبعادها لهن". وللتحقق من صدحة الفـرض تم إجـراء معـاملات الارتبـاط باستـخدام معامل ارتبـاط بيرسـون

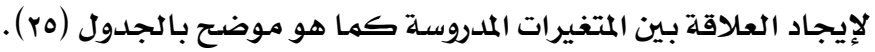
جدول (ro) قيم معاملات الارتباط بين المتغيرات المستقلة والمتغيرات المدروسة مورسة

\begin{tabular}{|c|c|c|c|c|c|c|c|c|c|c|c|}
\hline كلائل الألكفاءة & |الحقيقية في في & |القدرة على & | الإنجاز ككل & بالنفس & الابتكار & المخسوبة & المنافسة & الشعمية & بلابلرة الجلى & | تحمل | & لبعض الأجهزة الألردام ربات \\
\hline$\cdot, \wedge 9 \%$ & $* *, V Y Y$ & $* *, \vee \vee \wedge$ & $* *, \quad \vee r r$ & $* *, \wedge r V$ & $* *, \quad \vee \leq 9$ & $* *, q, \%$ & זrt, • & $* *, \vee \vee \vee \wedge$ & $* *, 910$ & $\because *, \wedge$. . & |الاستخدام الصحيح|| \\
\hline & & & & & & & $* *, \vee \wedge \neg$ & $* *, \Lambda T Y$ & $* *, V \leq \varepsilon$ & $* *, v \mid r$ & السليه \\
\hline$* *, V r r$ & *., ד ד & $* *, 9 \% 7$ & $* *, \wedge \diamond 0$ & $* ., 710$ & $* *, \wedge$, $q$ & $* *, q \mu r$ & $* *, \wedge, r$ & $* *, q, v$ & $*, 7 \leq 1$ & $* *, \wedge \vee \wedge$ & التخزين السليم \\
\hline & & & $* *$ & $\approx *, \wedge \vee$ & & $* *, v \vee 0$ & $* *, \wedge$ & צ $* *, \wedge r$ & $* *, v \diamond r$ & $* *, \wedge \div \wedge$ & |الأجهزة المنزلية استخدام بعض |الحديثة ككل \\
\hline
\end{tabular}

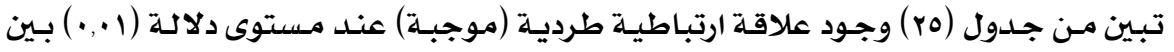

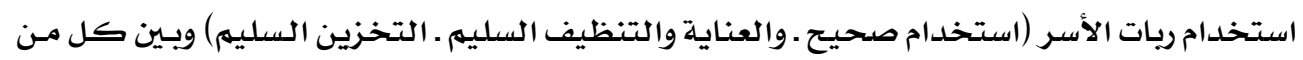

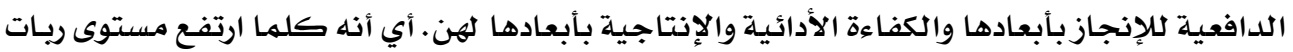

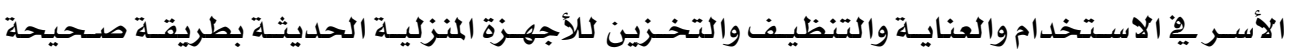

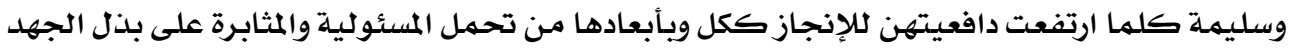

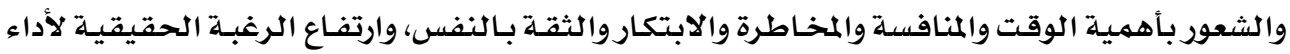

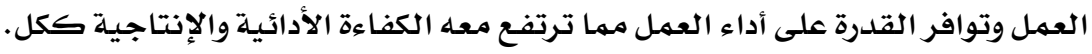

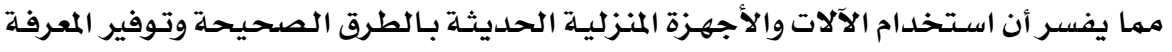

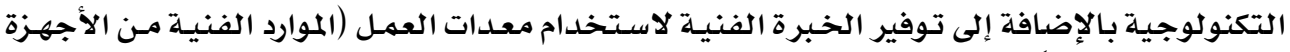

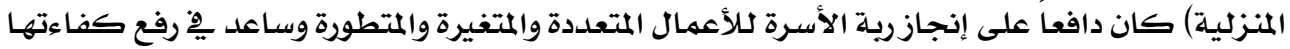
الأدائية والإنتاجية. 


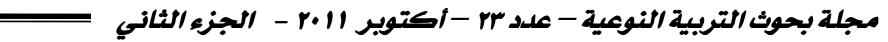

يتضـح مهـا سـبق وجـود علاقـة ارتباطيـة بــين اسـتخدام ربـات الأسـر لبعض الأجهـزة المنزليـلة

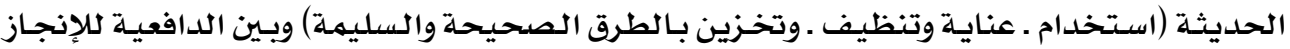

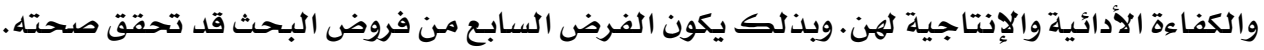

ا ـ أن تقوم كليـات الاقتصاد المنزبـي وأقسام الاقتصاد المنزلـي بكليـات التربيـة النوعيـة باعتبارهـا

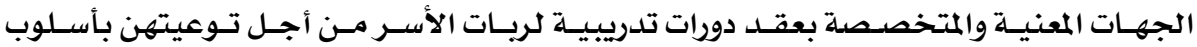

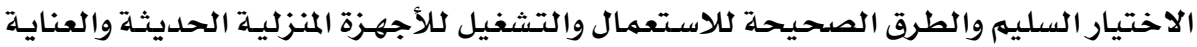

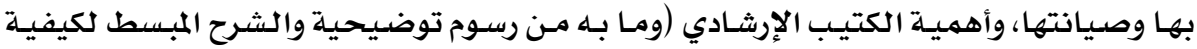

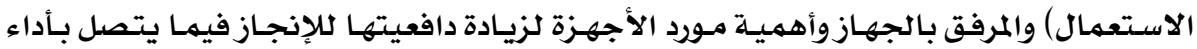

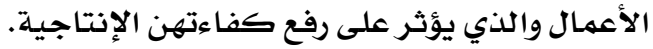

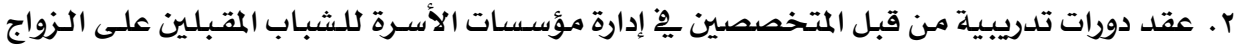

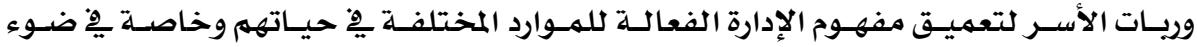

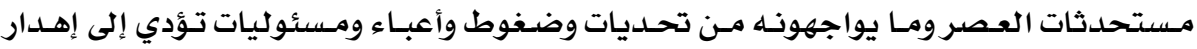

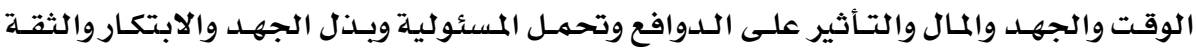

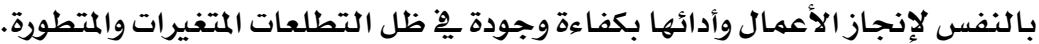

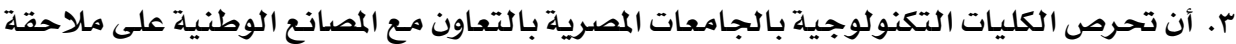

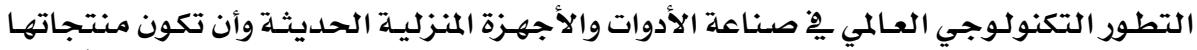

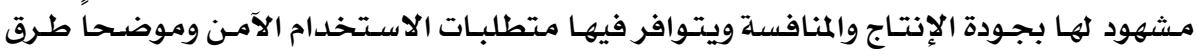

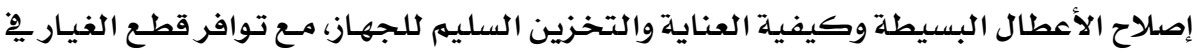
الأسواق بأسعار مناسبة.

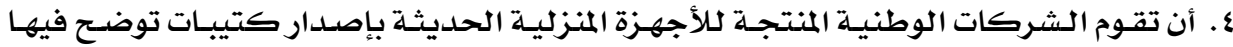

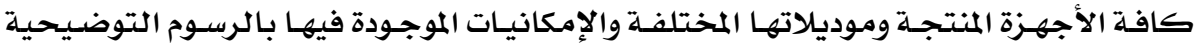

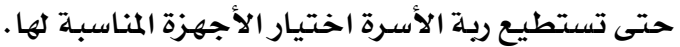

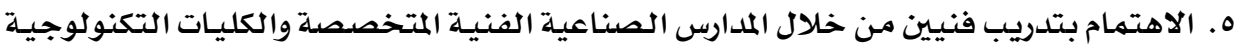

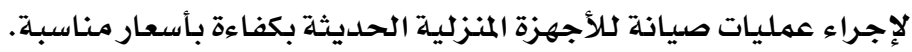

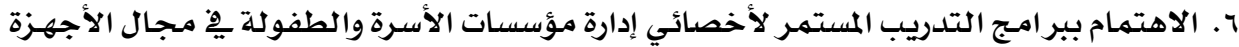

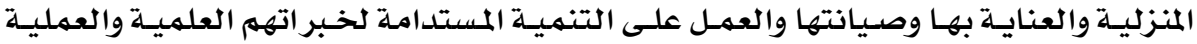

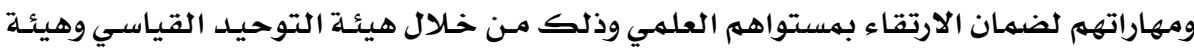
حماية المستهلك. V. وإعمالاً بذلك يمكن وضع تصور مقترح لبرنـامج تنميـة وعي ريـات الأسـر والمقبلين على الززواج

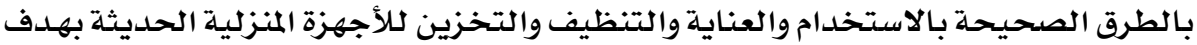

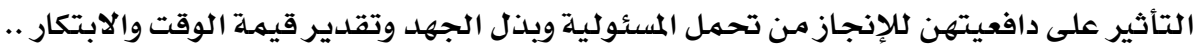
الخ لأداء الأعمال بكفاءة وجودة يِّاء ظل التغيرات التكنولوجية والتطلعات المتغيرة والمتطورة. 
برنامج بالعرض 
مجلة بحوث التربية النوعية - علد سr - أكتوبر ll - - الجزء الثاني ب 
1. إجلال إسماعيل حلمي (1999) : العنف الأسري، القاهرة، دارقباء للطباعة والنشر.

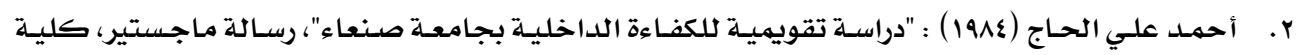

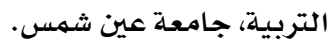
r. أحمد محمد عبد الخالق، مايسة أحمد النيال (1991) : الدافع للإنجازوعلإقلاقته بالقلق والانبساط، مجلـة

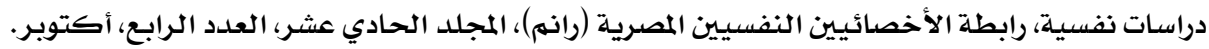

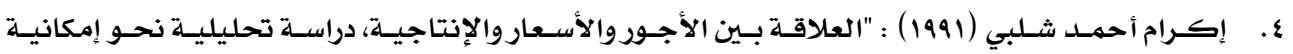

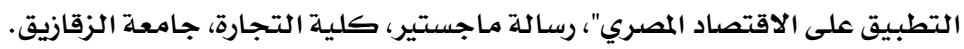

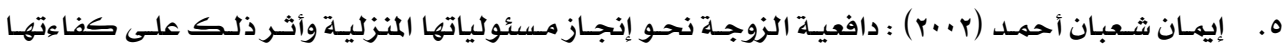

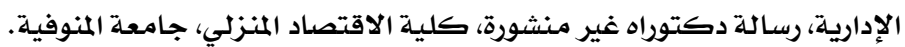

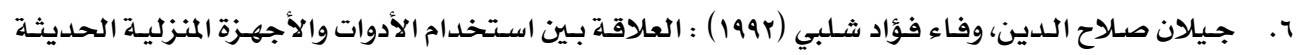

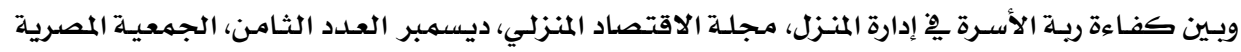
كلاقتصاد المنزلي، القاهرة، مصر.

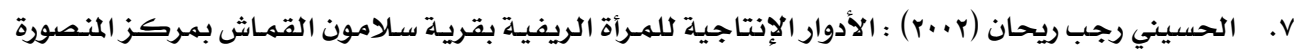

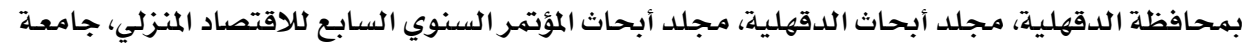
المنوفية.

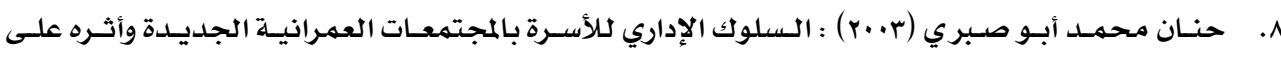

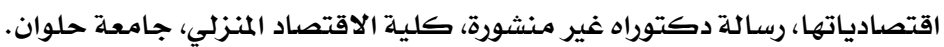

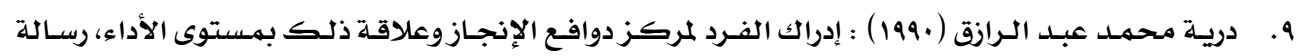
دكتوراه، كلية البنات، جامعة عين شمس.

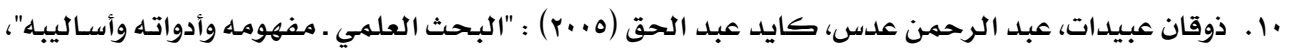

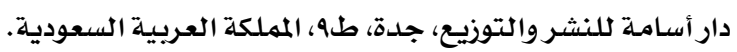
11.

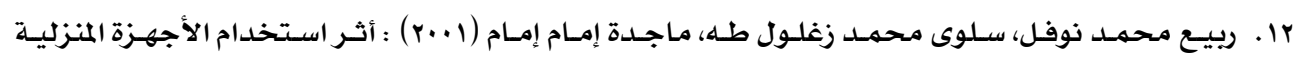

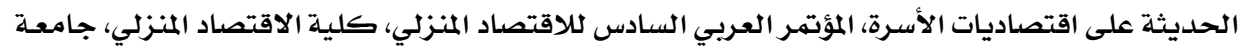

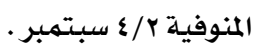

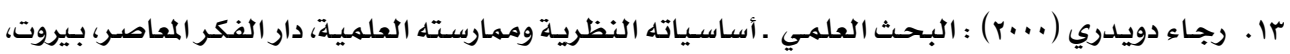
لبنان. ع ا. رسمية علي خليل (1971) : الإرثاد النفسي، مكتبة الأنجلو المصرية، القاهرة.

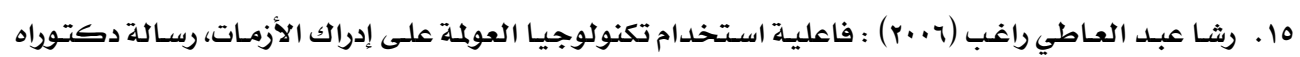
غير منشورة، كلية الاقتصاد المنزلي، جامعة حلوان. 


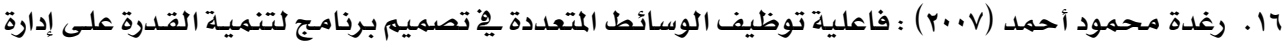

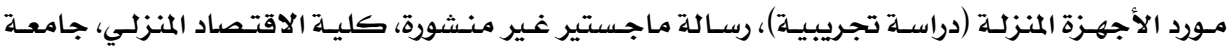
حلوان. IV . زينـب محمـد حقي، ناديـة حسن أبـو سـكينة (1991) : علاقة إدارة مـوارد الأسـرة بـعوبات التوافق النفسي

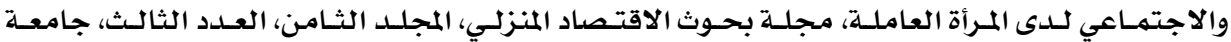
المنوفيـة.

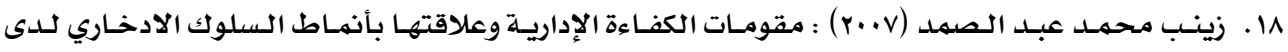
الزوجات بمدينة جدة، مجلة بحوث الاقتصاد المنزلي، جامعة المنوفية، مـجلد (IV)، العدد (ع )، أكتوبر.

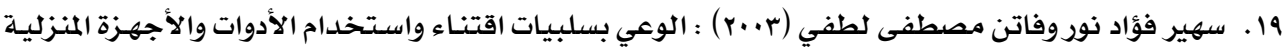

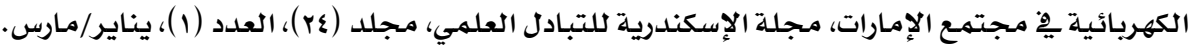
•r. ·. السيد يس (1999) : "العولمة والطريق الثالث"، ميريت للنشر والمعلومات، القاهرة.

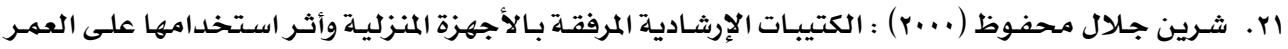
الاقتصـادي للجههاز، رسـالة ماجستير غير منسشورة، كليـة الاقتصـاد المنزلي، جامعـة المنوفيـة، شبيـن الكوم، مصر. r.r. صلاح أحمد الشرنوبي (1999) : إدارة الأفراد والعلاقات الإنسانية مدخل الأهداف، مؤسسـة شباب الجامعـة،

$$
\text { الإسكندرية. }
$$

r. . صلاح عبد السميع باشا ( .... ) : أثر الدافع للإنجازوتقدير الذات والتخصص يخ التحصيل الدراسي لدى طلاب المرحلـة الثانويـة العامـة، مجلـة البـحـوث النفسيـة والتربويـة، كليـة التربيـة، جـامعـة المنوفيـة، العـدد الثالث، السنـة 10.

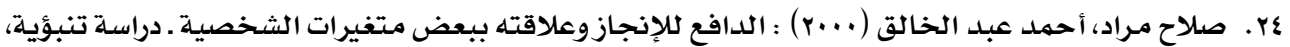
مجلة علهم النفس المعاصر والعلوم الإنسانية، المجلد الحادي عشر، العدد الرابع، القاهرة.

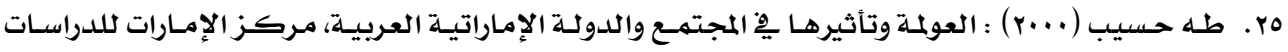
والبحوث الاستراتيجية والمبتكرات، الإمارات العربية المتحدة.

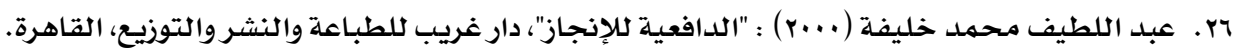

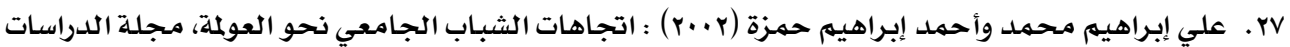

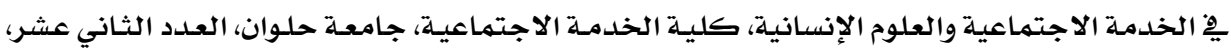
أبريل. ^^. علي السلهي (1990) : إدارة الأفراد والكفاءة الإنتاجية، دار غريب، القاهرة. هو. فؤاد أبو حطب وآمال صادق (1991) : مناهـج البحث وطرق التحليل الإحصائي يِّ العلوم النفسية والتربيـة الاجتماعية، مكتبـة الأنجلو المصريـة، القاهرة.

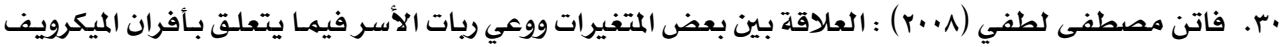
(دراسـة مقارنـة بـين ربـات الأســر العـامـلات وغـير العـاملات)، المؤتمر السـنوي الـدولي الأول، العريـي الرابـع، 
الاعتمـاد الأكـاديمي لمؤسسـات وبـرامج التعليم النـوعي ِِّ مصر والعـالم العربي "الواقع والمأمول"، كليـة التربية النوعية بالمنصورة، ^/9 أبريل.

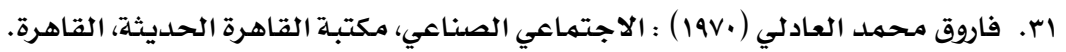

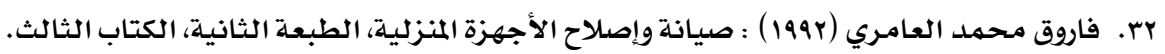

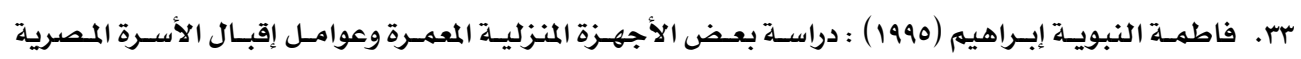

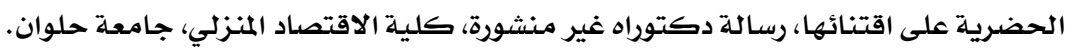

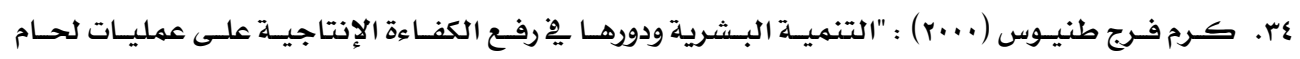

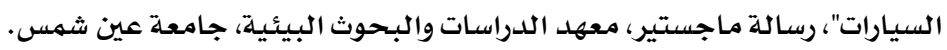

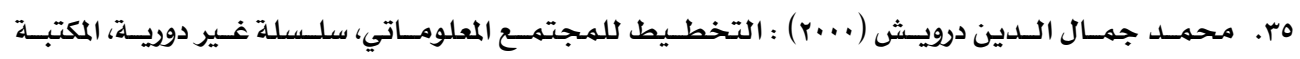
الأكاديمية، القاهرة.

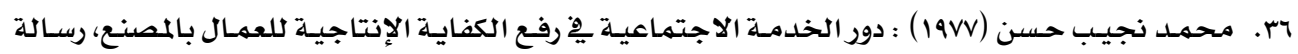

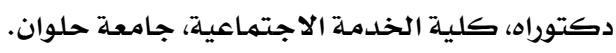

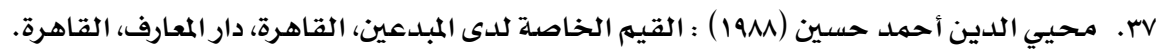

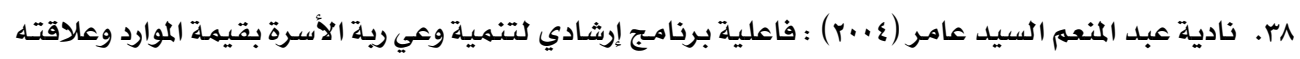

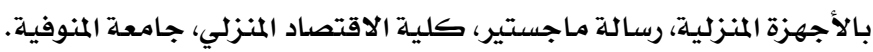

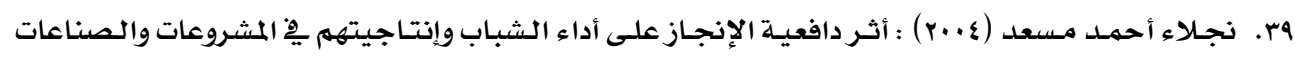
الصغيرة، رسالة دكتوراه، كلية الاقتصاد المنزلي، جامعة المنوفية.

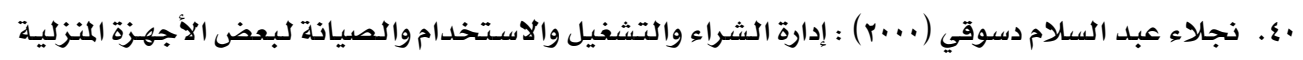

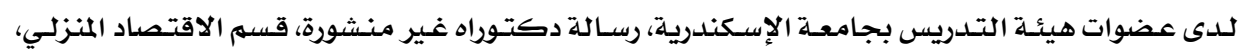
كلية الزراعة، جامعة الإسكندريـة.

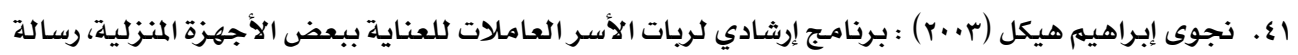

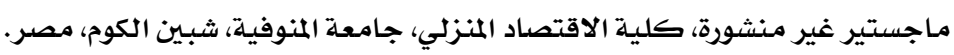

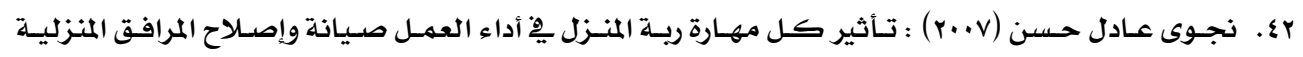

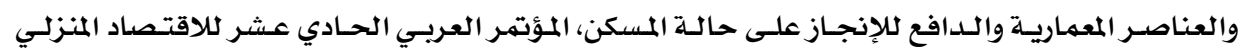

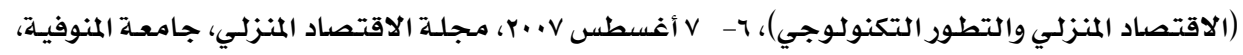
عدد (r).

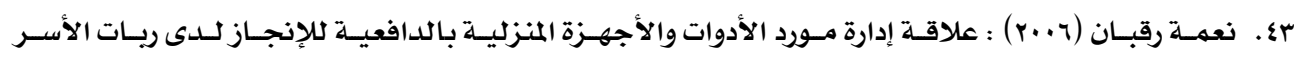

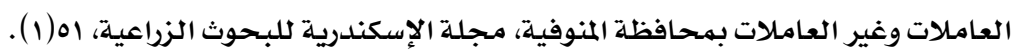

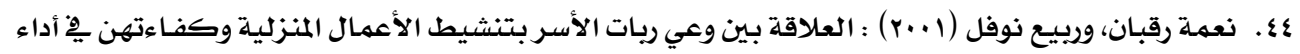

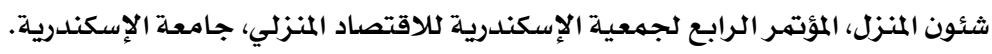

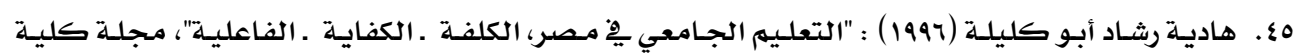
التربية، جامعة المنصورة، العدد الثالث. 


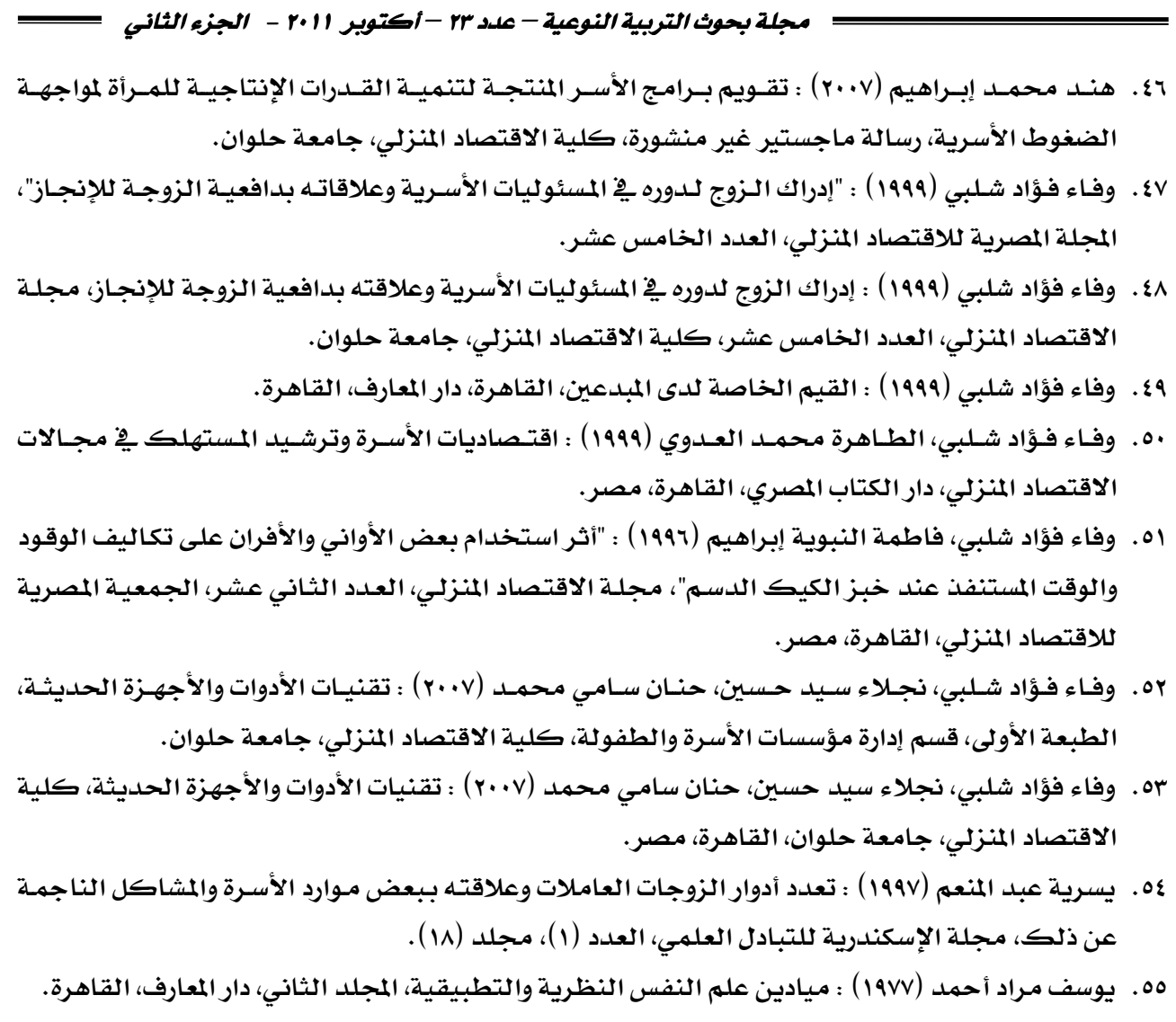

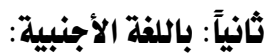

56. Brodie, J. (1981): The effect of selected family variable on the achievement motivation of employed women, $\mathrm{PhD}$, Thesis Minnesota University, U.S.A.

57. Carlton, J. Gallawa (2008): The complete Microwave oven service handbook (Operation, Maintenance, Troubleshooting and Repair), Microtech, Gonzalez, Florida, (http://www.gallawa.com).

58. Carlton, J. Gallawa (2008): The complete Microwave oven service Handbook Coperation, Maintenance, Troubleshooting and Repair), Microtech, Gonzalez, Florida, (http://www.gallawa.com).

59. Darley, J.M. (1987): Psychology New Gersy Prentice Hall, Inc. Englewood Cliffs.

60. Food Science Australia Fact Sheet (2005): The safety of Microwave Oven, (www.foodscience.Afisc.cairo.au/consumer). 
61. Garva Vuokko, T. Sinikka (1996): Fimility Economic crisis and survival in the light of futures, finish society for future studies, Vol. (58-61).

62. Grava, Vokko, I. Simikka (1996): Family economic crisis and survival in the light of futures finish society for future studies, Vol. (58-61).

63. Kelly Classic (2008): Microwave Ovens, Health Physics Society, (www.hps.org).

64. Mozinga, N.J. (1996): Influencing factors of child's motivation to achieve in school : Television viewing, gender, and number of parental figures, Vol. 31-40 of Dissertation Abs. International, P. 1941.

65. Mozingo, N.J. (1996): Influencing factors of child's motivation to achieve in school television viewing gender and number apparental figures, Vol. 3140, Dissertation Ab. Stract Internationa.

66. Robert, A.P. (1983): Perceived causes of small business failures, American Journal of Small Business, Vol. VII, No. 1.

67. Sara, L. \& Diane, W. (1984): Productivity, Problems prospects, and policies, (London, Johns Hopkins), PP. 15-17.

68. Schults, G.F. (1993): Socio-economic Advantage and Achievement Motivation Important Mediators of Academic Performance in Minority Children in Urban Schools Indiana Div of Education, Gary, USA, Urban Review, Vol. 25, (3).

69. Tracey, W.C. (1989): The relationship of collage students achievement motivation to family cohesion and aspiration : An analysis by race and genger, Disser Abs. Inter., Vol. 50, No. 7. 